Historic, Archive Document

Do not assume content reflects current scientific knowledge, policies, or practices. 


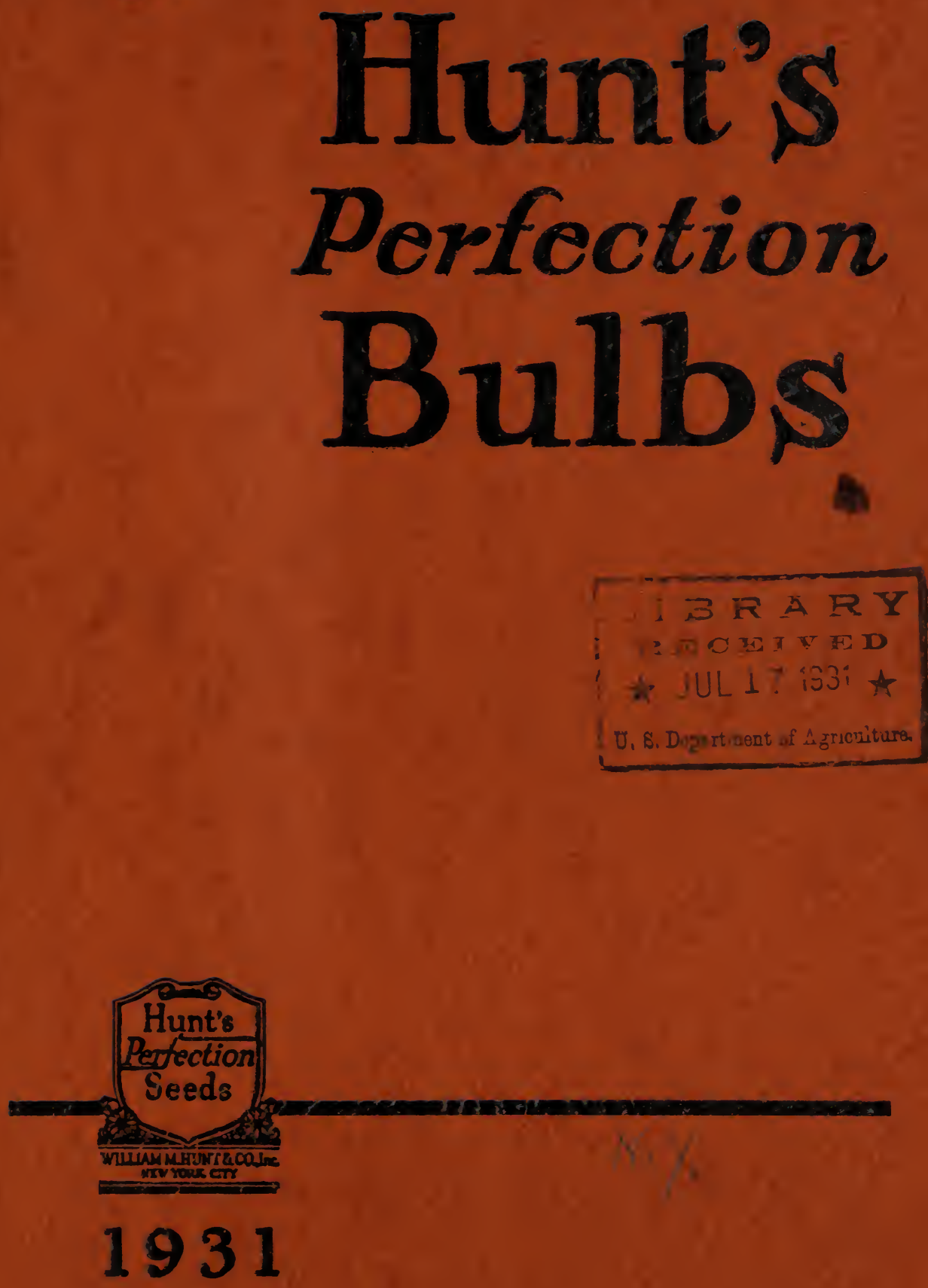


\section{HOW TO GROW BULBS}

Daffodils and Crocuses may be planted in the garden between the first of September and the middle of October; Tulips the latter part of October, but should not be delayed too long if best results are desired. Earlyplanted bulbs come up more evenly, earlier, and develop finer flowers than those put in Iater. Hyacinths may be planted any time from September to December.

When grown in beds, Hyacinth and Tulip bulbs should be planted at a uniform depth. The easiest way to do this is to remove all soil from the bed to the depth required, set the bulbs as far apart as the planting-table indicates, and carefully replace the soil. Many people do not think this is worth while; they prefer to plant with a trowel or dibble. Where this practice is followed, great care should be taken to see that the base of the bulb is pressed firmly into the soil.

After the ground is frozen to a depth of 4 to 5 inches, it is well to put on a cover of straw or leaves. This should be removed rather early in the spring. Tulips and Hyacinths should be taken up each year. Let the foliage mature, either where they have flowered or in another location. After drying, the bulbs should be kept in a cool, dry place.

Daffodils may remain in the same place for three to four years at a time. The clumps may then be taken up and divided for replanting.

Crocuses give a delightful effect in early spring, but, like Narcissi, should not be planted where grass is kept clipped. They are extremely desirable in naturalistic plantings, but to obtain good effects it is essential that they be used in large quantities; plan to use several thousand in each 50-foot square of woodland or meadow.

Lilies demand good drainage. This may be secured by placing a quantity of sand below each bulb, or by mixing peat or humus with the soil. The tall varieties should be planted in a location where they receive protection from high winds; all of them enjoy partial shade.

Culture Indoors.-Paper-White Narcissi and the Chinese Sacred Lilies are the easiest to grow. A bowl of pebbles and water is the "garden." Hyacinths likewise present little difficulty. Place each bulb in a glass so that the base barely touches the water, and leave them in a cool, dark

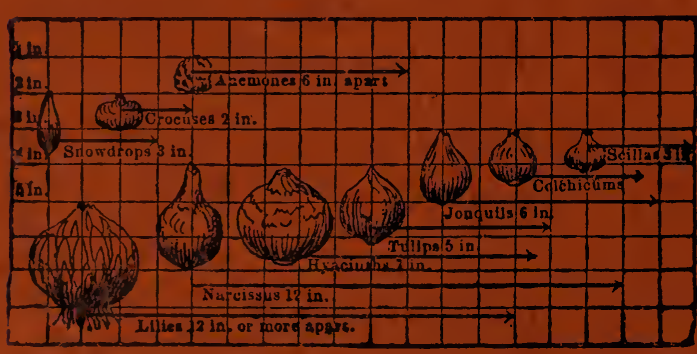

Many of our customers are frequently puzzled to know proper depth and distance apart at which bulbs should be planted. The accompanying diagram conveys the information very clearly. The chait will bear careful study. place until the roots develop. They may then be brought into the light, and will produce just as fine flowers as if they were grown in pots or outdoors. Start the bulbs any time between September and January; for succession of bloom bring them into the light at intervals of several weeks. 


\section{A Brighter Future}

There is, at this time, ample evidence that the low mark of the country's business depression has been reached.

The coming of normal conditions is almost a positive fact. Therefore, now is the time to order your Garden Bulbs of the highest quality.

You are invited to take a trip through our Catalog and note for yourself the splendid list of New and Recent Introductions as well as Standard Varieties of the Finest Bulbs that can be grown, offered at unusually low prices. 


\section{- To Our Friends and Customers}

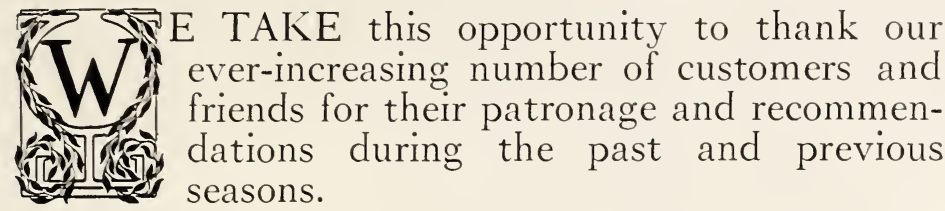

We have greatly improved our list of bulbs by adding many novelties and recent introductions from foreign and domestic growers of the best reputation, and we commend them to your consideration when placing orders.

Growing conditions abroad have been ideal, the crops large, and we are happy to announce that prices generally have been considerably reduced.

\section{ALL OUR BULBS ARE TOP SIZE, THE FINEST OBTAINABLE}

Please notice particularly that the Federal Quarantine Act, now in effect, prohibits the importation of all Narcissus. Our list of American-grown bulbs of Narcissus represents the leading popular sorts and novelties, and may be relied upon to give satisfactory results. As the demand usually exceeds the supply, early buying is suggested.

Early Ordering. Your coöperation is invited. Placing orders early will facilitate delivery at proper time.

Rush Orders may be telegraphed or telephoned at our expense.

Prices of Bulbs, Seeds, Plants, and Supplies are subject to market and tariff changes.

Terms. Prices quoted are net and do not include free transportation, except for seeds in packets, ounces, or quarter-pounds, on which we prepay postage or express to any point in the United States.

Upon delivery of goods to the carrier, ownership passes to the purchaser; when the carrier issues a receipt our responsibility ceases. Claims for damage should be made to the transportation agent at point of delivery.

Non-Warranty. William M. Hunt \& Company, Inc., give no warranty, express or implied, as to description, quality, productiveness, or any other matter of any seeds, bulbs, or plants they send out, and they will not be in any way responsible for the crop. If the purchaser does not accept the goods on these terms, they are to be returned at once.

\section{WILLIAM M. HUNT \& COMPANY, Inc. 115 West 45th Street, New York City}

June 25, 1931.

Telephones $\left\{\begin{array}{l}\text { BR yant } 9-3547 \\ \text { BR yant } 9-3548\end{array}\right.$

Copyrigbted, 1931, by William M. Hunt of Company, Inc. 


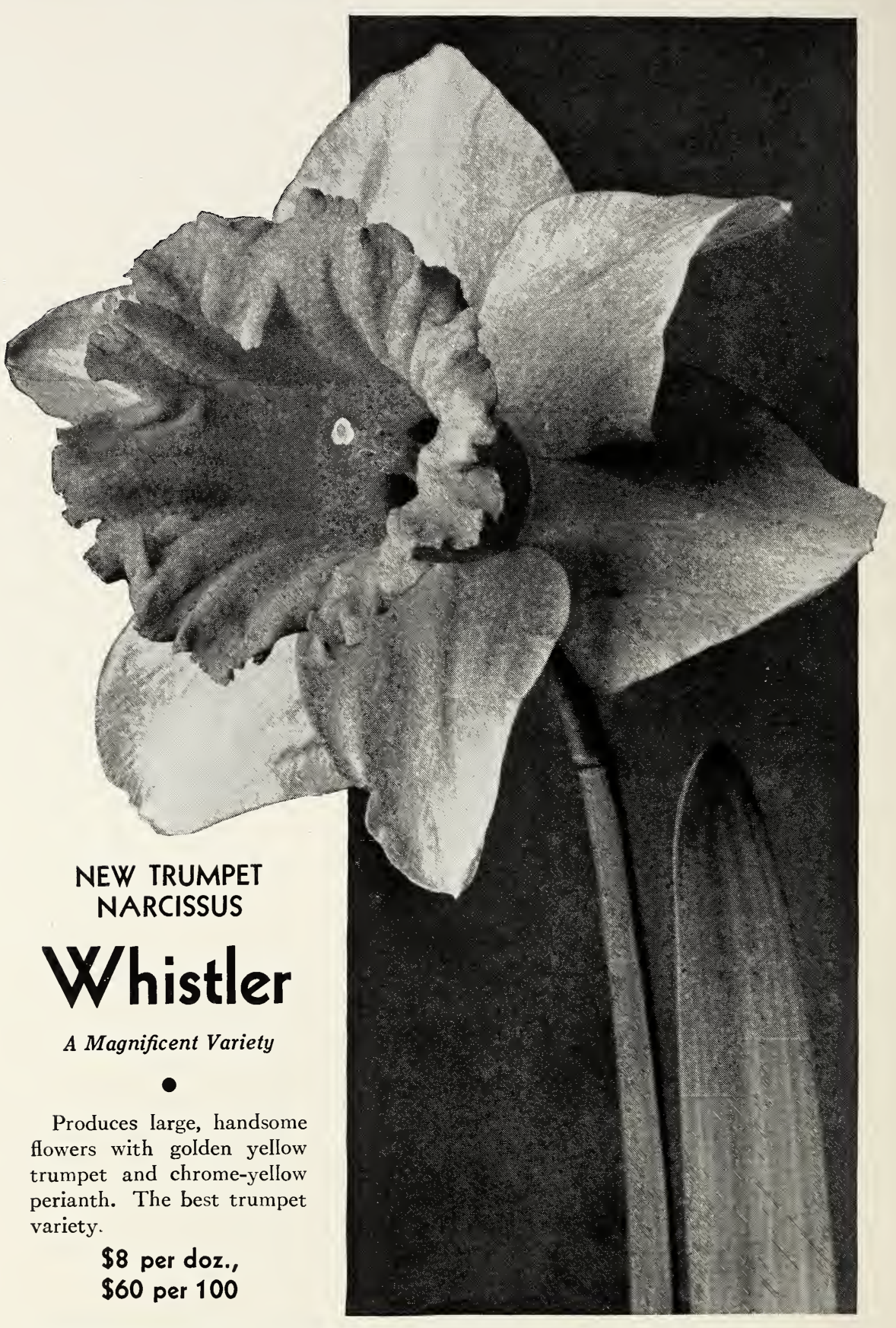




\section{Hunt's PERFECTION Bulbs}

\section{Darwin Tulips}

\section{N. B.-OUR TULIP BULBS ARE ALL TOP SIZE}

Undoubtedly, Darwin Tulips are increasing in popularity every season. The colors range from white to purplish black, including shades of crimson, violet, brown, rose, etc. Very effective for planting in shrubbery or in hardy plant borders. The flowers are large, deeply cupped, and are borne on lofty stems which are ideal for cutcing and vase use. Gorgeous combinations of color can be made by planting them in broad masses or Iong, narrow borders. To avoid striking contrasts, use tones of bronze and pale violet with the Iavenders - and soft pinks and lavenders, shades which merge into each other and do not clash as violently as the usual red and yellow. If striking effects are desired, try Bleu Aimable in front of City of Haarlem, a vivid, odd, French combination of blue and scarlet; or an even more effective combination of some pale yellow, like Flava (a Cottage Tulip) with a deep red-purple variety, Philippe de Comines or Zulu. The new pale yellows are also good with dark mahogany-red varieties like King Harold. Brilliant reds like Pride of Haarlem and Farncombe Sanders, are best used alone, or against an evergreen background. Dark pinks are good with light pinks and white varieties, like the Cottage Picotee. Forget-me-nots are especially good to associate with pink Tulips. Those marked with * are best for forcing.

Afterglow. 26 in. Possibly the sweetest color-play found in Dar- Doz. 100 1,000 wins-rich deep rose Iaid over salmon-orange, clearer toward the edges; inside a lovely orange-topaz sheen. Promotes harmony in border plantings and looks well in Iarge formal beds . \$1 00

Anton Mauve. 28 in. Enormous flowers of duIl old-rose-purple outside, with duII grayish lilac edges; inside of the petals reddish violet-blue overspread with grayish brown; white base with black anthers. Very tall, strong stems giving the flowers great beauty and dignity .

Anton Roozen. 28 in. Rose-pink, edged with pale rose; blue and white base. Large cup-shaped flower of rare beauty . .

Aphrodite. 30 in. A dark rose-pink flower throughout with a white base suffused with palest blue. Flowers of medium size on very tall, stiff stems. An improvement on Loveliness . .

Aviator Hawkes. 30 in. Very Iarge, cup-shaped blooms of rich rose-pink with large white base, borne erect on strong, stiff stems. . . . . . . . . . . . . . . . . . .

*Baronne de la Tonnaye. 30 in. Blush-rose, medium-sized flower with a salmon glow in the center and brilliant black anthers. A tall, handsome variety fine for bedding and forcing . . . .

*Bartigon. 28 in. Flower carmine-red; base pure white edged violet. Splendid for forcing .

Bene Est. 32 in. Very large and most attractive flowers of pale canary-yellow accentuated by glittering black anthers. YeIIow is a new and rare color in the Darwin race. . . . .

Bleu Aimable. 26 in. Bright purplish blue, intensely rich inside. A beautiful flower of very unusual shape and one of the clearest "blues" .

$75 \quad 450 \quad 4000$

Bleu Celeste. 28 in. Pale clear mauve flowers of large size, with a large white base tinged blue. One of the best of its color .

*Centenaire. 32 in. Violet-rose with white base. Early, outdoor flowering, and excellent for forcing. A very handsome, rich color, enhanced with a duIl blue base and glittering black anthers. Stems straight and taII . . . . . . . . .

* Chant de Cygne. 30 in. Beautiful variety of recent intro-

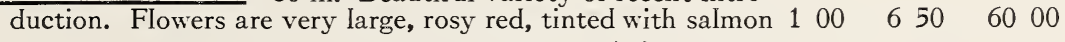




\section{William $M$ iNCORPORATED $\operatorname{Humpany}$}

\section{DARWIN TULIPS, continued}

City of Haarlem. 32 in. Large flowers of brilliant, blazing ver- Doz. milion, so red that it dazzles the eyes in the sunlight. The handsomest and brightest red Darwin. Inside it has a blueblack center edged white. Splendid for bedding and late forcing.

*Clara Butt. 24 in. Deep rose-pink, inside still deeper, with blue base and white halo. For outdoors or forcing. The familiar old standby for pale shell-pink color-effects . . . . . . . .

Copper Bowl. 28 in. An appealing copper-yellow variety. Flowers of good form and substance. . . . . . . . . .

Dal Ongaro. 28 in. Large pale Iavender-violet flowers with pure white base. For bedding only. . . . . . . . . . .

Dream. 26 in. Pale heliotrope; inside violet with blue base. Handsome. Petals recurve most attractively. For bedding only.

Dresden China.

32 in. A seedling Darwin novelty of superlative merit. Flowers pale rose-pink, daintily tinted at the edges. Very bright and of most attractive shape . . \$2 each . 2000

Duchess of Hohenberg. 26 in. Purplish lilac-blue flowers, tinged in the center with gray-lilac and brown; large white base with brilliant black anthers

Duchess of Westminster. 28 in. A most handsome variety with medium-sized, bright rose-pink flowers, tinged with salmon; inside rosy scarlet, with a bright yellow base. . . . . . . .

Edmee (Beauty). 30 in. Purplish rose, edged deep rose-pink. An outdoor variety of distinct form. Very deep petals, forming a straight-sided cup. An extremely handsome and very desirable garden variety . . . . . . . . . . . .

Euterpe. 28 in. Silvery lilac-mauve, with pale lilac edge. A very clear, delicate lavender flower in general effect, and, undoubtedly, one of the best in this shade. . . . . . . .

*Farncombe Sanders. 30 in. Beautiful rosy scarlet, with pure white base; large flower, borne on long, strong stem. For forcing or bedding. . . . . . . . . . . . . . . .

Faust. 30 in. Purple-maroon with a superb dark sheen, appearing as nearly black from a little distance. Strong stems, standing like purple-headed arrows pointing to the sky . . . . .

*Feu Brillant. 26 in. Bright scarlet. Splendid for bedding and Iate forcing . . . . . . . . . . . . . . . . . . . . .

*Flamingo. 27 in. Daintily pointed petals and a ravishingly pure shell-pink color; impressive white center. For forcing . .

*Frans Hals. 28 in. Very large, handsome blooms of dark violet with a mahogany tinge, deep blue-black base, and black anthers. Very pleasingly scented. Excellent for forcing. . .

*Giant. 28 in. Gorgeous dark violet-purple flowers, richer and deeper inside, with a very small white base surrounded by a blue-purple star; anthers black. Tall, strong stems. Excellent for forcing and bedding. . . . . . . . . . . .

Glow (Claude Gillot). 24 in. Brilliant crimson-red, inside currant-red. For beds or borders. . . . . . . . . . .

Golden Fleece. $30 \mathrm{in.} \mathrm{Huge} \mathrm{blooms} \mathrm{of} \mathrm{intense,} \mathrm{rich} \mathrm{golden} \mathrm{yel-}$ low, tinged with bronze on the outside of the petals. An outstanding new variety ............

$1751100 \quad 10000$

$75 \quad 500 \quad 4500$




\section{Hunt's PERFECTION Bulbs}

\section{DARWIN TULIPS, continued}

Golden Ray. 32 in. A tall-growing golden yellow novelty-an unusual color among the Darwins. Should be extensively grown on account of its present moderate pricc.

Doz.

100

1,000

Jubilee. 31 in. Deep rich blue-purple. Large, somewhat eggshaped flower on tall, strong stem. Perhaps the best Darwin in this color.

Kathleen Parlow. 28 in. Large, handsome flowers of exceedingly graceful form. Pale rose-pink petals with silvery edges .

King George V. Perfect blend of cherry-red and scarlet, inside an orange-scarlet iridescence that speaks with eloquence when the flowers are half-open. Broad, recurved petals, which give a semi-double aspect to the flower. A bed of these flowers looks like so many fairy lamps. .

King Harold. 24 in. Dark garnet-red, inside brownish red with blue-black base and black anthers. The finest of the dark red Tulips, having an exquisite satin sheen on its beautifully recurving petals. Splendid among shrubbery .

La Candeur (White Queen). 24 in. Pale light lilac, passing to lilac-white as the flower ages. Extra-fine variety for planting outside.

La Fiancee. 30 in. Large and beautiful rose-colored Tulip shaded mauve and edged light pink; blue base. WeIl recommended.

*La Tristesse. 24 in. DuII slate-violet with lighter edges; white base. Excellent for forcing. . . . . . . . . . . . . .

*La Tulipe Noire (The Black Tulip). 30 in. Very dark reddish black with velvety flush; white starred base. Very attractive in a border

Louis de la Valliere. 28 in. Lovely, lily-like flowers of coralpink, suffused in the center with strong salmon and having a glistening sheen; small blue base and black anthers. One of the finest pink varieties on tall, strong stems. . . . . . . .

*Madame Krelage. 28 in. Bright lilac-rose, margined pale silvery rose; inside deep peach-blossom pink. One of the leading varieties for early forcing. . . . . . . . . . . . .

Massachusetts. 28 in. Splendid pale rosy carmine, bordered rosy white; white base marked pale blue. For planting in beds or borders.

Mount Erebus. 32 in. An enormous pure white variety on extremely tall and very strong stems. Probably the finest of all white Darwin Tulips. . . . . . . . \$3 each . 3000

Mr. Van Zyl. 30 in. An enormous flower of striking beauty. Bright pink with pale shell-pink edge. A very large, improved Rosabeila . . . . . . . . . . \$3.50 each . 35

Mrs. Potter Palmer. 28 in. Bright, pure purple, globular flowers of superb texture and character. One of the finest bedding varieties in this distinct and lovely shade. Very attractive for border. . . . . . . . . . . . . . . . . . . . .

*Nauticus. 30 in. Large, dark rose flower, center clear violet. Equally good outdoors and for forcing ......... 


\section{DARWIN TULIPS}

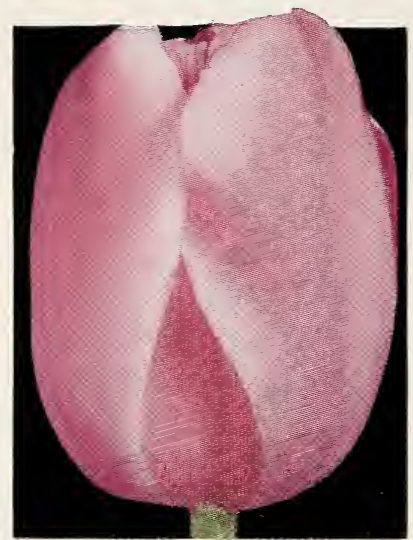

La Fiancee

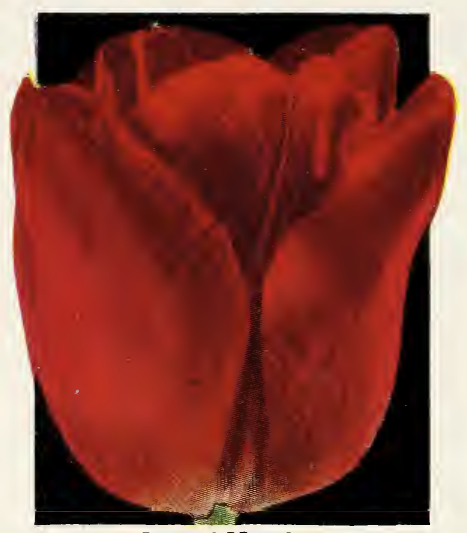

City of Haarlem

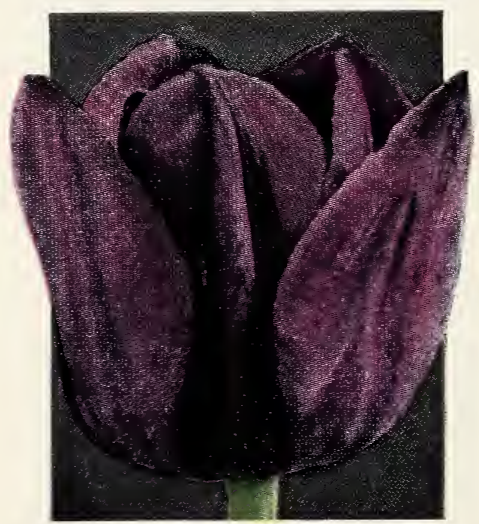

Giant
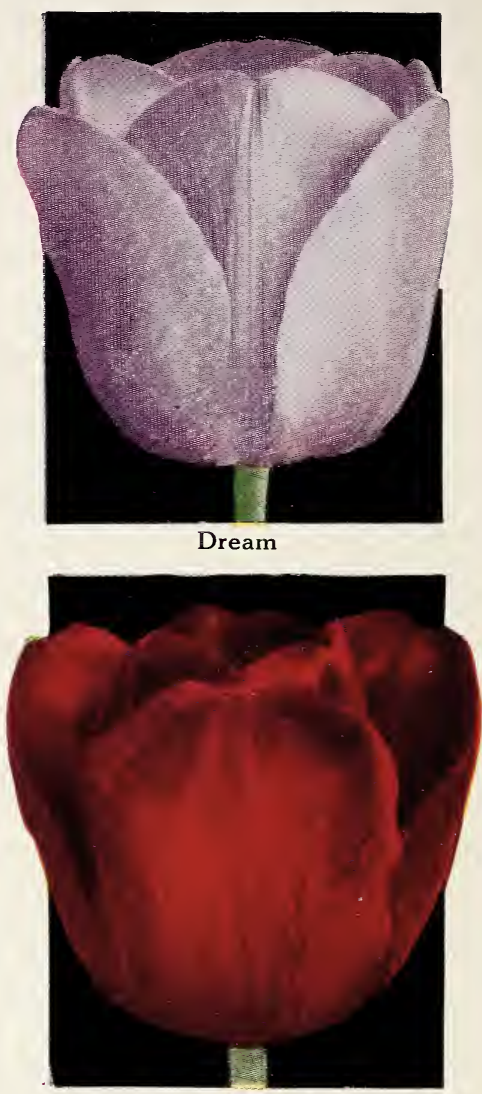

King Harold

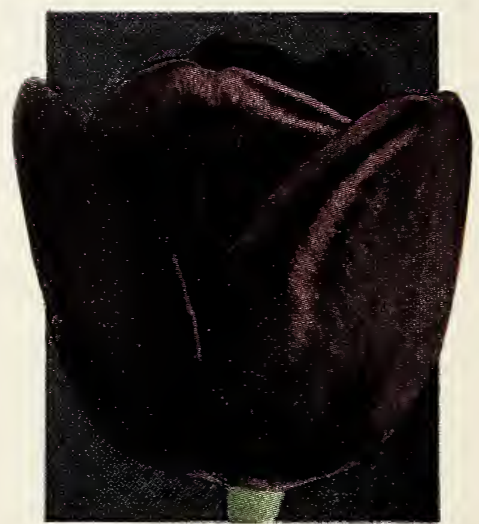

La Tulipe Noire

SPECIAL AMATEURS' COLLECTION

Twenty-five (25) each of above six varieties $\$ 900$

Packed and labeled separately Sent prepaid to any address east of the Mississippi for cash with order 


\section{Hunt's PERFECTION Bulbs}

\section{DARWIN TULIPS, continued}

Petrus Hondius. 28 in. Shining rose-pink, a little lighter at the edges, with a brilliant blue base edged with violet; anthers shining black. A splendid pink variety with broad, reflexing petals like a rose-bud before opening. Elegant stem and carriage . . . . . . . . . . . . . . . .

Philippe de Comines. 26 in. Velvety purple, with white base. Large flower on stiff stem

Doz. $\quad 100$

1,000

$\$ 0 \quad 75 \quad \$ 500 \quad \$ 4500$

$\begin{array}{llll}75 & 500 \quad 4500\end{array}$

*Pride of Haarlem. 30 in. Brilliant crimson-red, with blue base. Extra-fine for planting outside and one of the leading varieties for forcing. Very fragrant . . . . . . . . . . .

$\begin{array}{lllll}60 & 3 & 50 & 30 & 00\end{array}$

*Prince of the Netherlands. 32 in. Soft carmine, edged silvery pink; inside cerise-scarlet; white and blue base. A wellformed flower on strong stem. Very good forcer . . . . . .

*Princess Elizabeth (Julie Vinot). 28 in. Dull crimson-pink, edged soft rose-pink; white base. Well-formed flower of great substance. Good forcer and one of the best pinks for outdoors.

*Professor Rauwenhof. 28 in. Bright cherry-red with scarlet glow and brilliant blue base. Beautiful flower on strong stem. Very good forcer . . . . . . . . . . . . . .

${ }^{*}$ Reverend Ewbank. 26 in. Bright bluish Iavender, flushed brown inside; edges of petals soft heliotrope, with silvery gray bloom; white base. Attractive color. Forces splendidly .

*Ronald Gunn. 26 in. Violet, edged pale Iavender; white base. Especially recommended for pot-culture . . . . . . . .

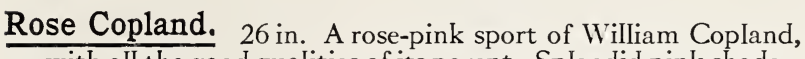
with all the good qualities of its parent. Splendid pink shade .

*Sieraad Van Flora (Queen Flora). 26 in. Soft lilac-rose; white base with blue mark. Splendid for early forcing. One of the best pinks................

Sir Trevor Lawrence. 33 in. Violet-maroon, tinted light purple. Very large, cup-shaped flower on long stem . . . . .

Sulphur Queen. 30 in. Extremely Iarge, pure light yellow flowers of perfect form on tall, stiff stems . . . . . .

*Sundew. 28 in. A striking bright red novelty. The petals are fringed and cut in a most attractive manner. Suitable either for outdoor purposes or forcing. Created a great impression wherever shown . . . . . . . . . .

The Bishop. 28 in. Dark reddish violet with a gray bloom on the outside of the petals; rich violet inside, with a small white center edged with blue; black anthers. Flower has a beautiful ovoid form, the outer petals recurving as it develops. Strong, upstanding stems

Venus. 28 in. Large, spreading flowers of clear, bright rosepink with a waxy bloom outside. The center of the flower presents a remarkable contrast of rich rosy pink petals; white base edged with duIl blue; shining black anthers

*William Copland (Sweet Lavender). 26 in. Reddish Iilac. When forced the color is a beautiful Iavender, with white base marked blue. Recommended for forcing only . . . . 


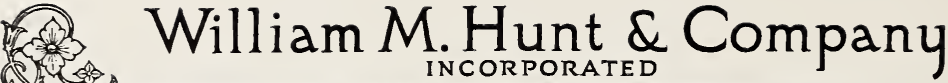

\section{DARWIN TULIPS, continued}

*William Pitt. 28 in. Dark crimson, with purplish bloom on the Doz. $100 \quad 1,000$ outer petals; white base edged blue . . . . . . . . $\$ 075 \quad \$ 450 \quad \$ 4000$

Yellow Giant. 30 in. Huge, clear canary-yellow flowers of massive, open form, held erect on tall, stout stems. A splendid variety for exhibition ........ \$1.25 each . 1350

Zulu. 28 in. Violet-black, with shining purple edge; white base with blue mark. Large, egg-shaped flower . . . . . . . .

Zwanenburg. 32 in. Very beautiful, medium-sized flower of sparkling white with tiny hair-lines of dark purple. The outside petals recurve in a handsome fashion and the center is marked with six shining black anthers.

DARWIN TULIPS MIXED. Top-size bulbs only. Our mixture contains all the above varieties, in a proper proportion. For massing in borders and for cutting . . . . . . . . .

$60 \quad 350 \quad 3000$

Special Amateurs' Collections. 250 Darwin Tulips in 10 distinct and separate varieties, Special Amateurs Collections. our selection, for $\$ 11 ; 100$ Darwin Tulips in 10 distinct and separate varieties, our selection, for $\$ 5$. Sent prepaid to any address east of the Mississippi for cash with order.

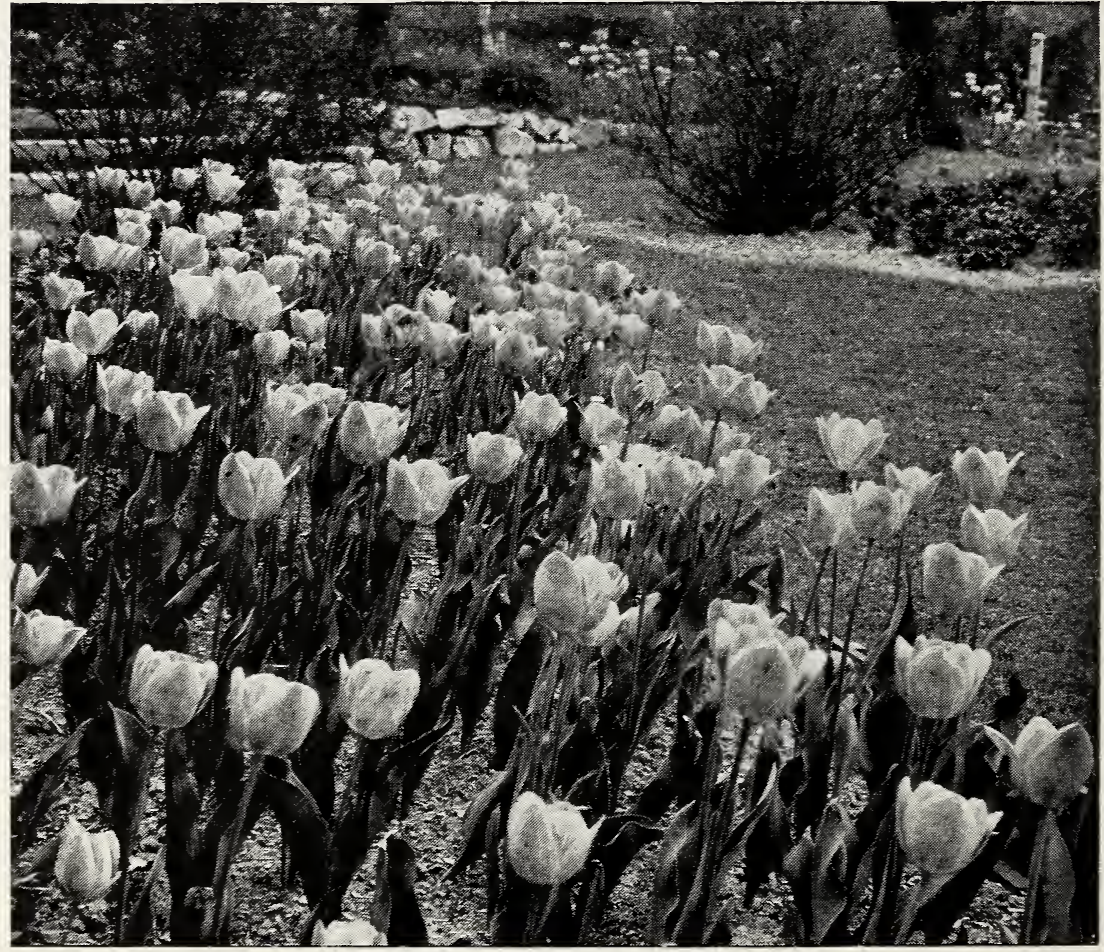

Planting of Darwin Tulips 


\section{Hunt's PERFECTION Bulbs}

\section{Cottage or May-flowering Tulips in Many Colors}

The largest flowers of any Tulips are found in this class, which contains many longpointed and lily-shaped flowers. AII colors imaginable are available among them, except good blues. Many have long stems and some are shorter and some gracefully drooping so that they are excellent in front of taller sorts. They are splendid for cut-flowers and are unsurpassed for garden decoration.

Alaska. 28 in. Long canary-yellow petals with butter-colored base, opening to an enormous flower of star-like shape. Halfopen, almost exactly like a Iily. Very lovely and distinct

Doz. $\quad 100 \quad 1,000$

Ambrosia. 25 in. Superb salmon-orange inside, with yellow and green patterned base; outside color subdued lilac-rose, with gay edging of bright coral or luminous apricot. A stunning, wide-open cup of unusual size. This masterpiece has had a meteoric rise during the few years since its introduction. Its delightful perfume is a great asset

Avis Kennicott. 24 in. Long chrome-yellow flower with black base and anthers. For bedding . . . . . . . . . . .

Aviso. 28 in. A beautiful shade of salmon-pink. The oval flower is supported on a fine strong stem. Well recommended.

Blushing Bride (Isabella; Shandon Bells). 16 in. Opens sulphur-yellow and turns to carmine-purple, with rosy white flakes. For bedding and forcing . . . . . . . . . .

Bouton d'Or (Golden Beauty). 20 in. Sunflower-yellow. Excellent cut-flower of cup form .......... .

Carrara. 24 in. Graceful, fairy snowballs on light green stems. Pure white, no other tints. Large, rounded cups. Does very well in pans in the greenhouse for middle-March blooms. Has many awards of merit for its perfect form, purity, and longIasting texture

$150 \quad 1000 \quad 9000$

Dido. $28 \mathrm{in}$. The delightful copper tints of the new roses can now be had in Tulips. In Dido the body-color is a deep coralpink, edging into light orange; the inside is like costly silk, flaming orange with green and yellow base. FuIl-blown flowers are $31 / 2$ inches deep and of captivating beauty . .

Dulcinea. 28 in. An extra-early forcing variety. Glowing orange-red, with yellow and greenish base . . . . . . .

Fairy Queen. 25 in. Violet-lilac, broadly margined coppery yellow. Perfectly formed flower and one of the most handsome varieties for bedding . . . . . . . . . . . .

$175 \quad 1250 \quad 11500$

$100 \quad 600 \quad 5500$

Geisha. 26 in. An unusual color-combination of violet and cream. Exceedingly large variety. Stock limited. \$1.50 each . 1650

Gesneriana lutea. 26 in. Lemon-yellow, inside buttercup-yellow. Fine. Sweet-scented . . . . . . . . . . .

Grenadier. 21 in. Flaming orange; very large flower of Iily-like form. The most brilliantly colored of all Tulips . . . . .

Idyll. 28 in. Almost globular. Color vivid rose, inside shaded salmon; pure yellow base with blue edges 


\section{William M. Hunt \& Company}

\section{COTTAGE TULIPS, continued}

Inglescombe Pink. $25 \mathrm{in.}$ Delicate rose-pink, tinted saImon; Doz.
blue center. An exceedingly useful and delicately Iovely variety, especially if grown in partial shade .... . \$0 75

Inglescombe Scarlet. 20 in. Scarlet; black base . . . . . . 75

Inglescombe Yellow. 23 in. Known as the yellow Darwin Tulip. Canary-yellow. For borders and cutting . . . . . . . .

Jeanne Desor. 28 in. This is really a cross between the Darwin and Cottage Tulips. Produces a Iarge flower of Darwin shape, carried on strong, tall stem. Its deep orange color and scarlet border are very striking. . . . . . \$1 each . 1000

John Ruskin. 18 in. Apricot-rose, shaded mauve, with pale yellow edge on petals . . . . . . . . .

Leda. $30 \mathrm{in.}$ One of the most beautifuI pink Tulips extantthe result of a cross between Darwin and Cottage Tulips. The bright rose flowers are of Darwin shape and are produced on strong, tall, straight stems ........... . .

Marchioness of Londonderry. 23 in. Amber-colored flowers tinged with soft yellow and light violet ....... .

Miss Ellen Willmott. 25 in. Soft chrome-yellow, changing with age to a deeper color. Strong stem . . . . . . . 100

Miss Holland. 26 in. Salmon-orange, shaded rose. A medium-sized flower of surpassing beauty . . . . . . 250

Mongolia. $28 \mathrm{in.}$ Produces an enormous, egg-shaped flower of very deep yellow. One of the most outstanding of recent introductions . . . . . . . . . \$1.75 each . 1950

Moonlight. 24 in. Cup-shaped blooms 4 inches deep and 2 inches wide may be produced with ordinary care. A semishaded position will give them that size. The color is a lovely strong yellow with a soft yellow bloom which gives the cup that pale moonlight tint for which it is famous. The wiry stems will stretch to 28 inches in semi-shade . . . . . . .

Mrs. Moon. 25 in. An especially good all-yellow of a rich deep tone. It is of unusual form, the long, flaring petals curving twice, producing a vase effect instead of a cup. Brilliant yellow inside. Good perfume. Fine stem. Goes well with plantings of the strong-toned Breeder Tulips . . . . . . . . .

Orient. $30 \mathrm{in.} \mathrm{Large,} \mathrm{bold} \mathrm{flower} \mathrm{of} \mathrm{remarkable} \mathrm{color-salmon}$ with bright rosy carmine and orange-red edges . . . . . .

Picotee (Maiden's Blush). 24 in. Cream-white, softly pink edged, changing to a deeper pink as the flower ages. Elegant shape. For cutting and bedding . . . . . . . . .

Pride of Inglescombe. $26 \mathrm{in.}$ This is a greatly improved Picotee. Cream-white, with soft pink edge changing to deeper pink. Especially recommended for cutting and bedding . .

Prince Hendrick. 28 in. A beautiful color-combination of orange-bronze and pink-rather difficult to describe. Very large flower. Strong-growing habit . . . . . . . . . . .

Retroflexa. 16 in. Soft yellow, graceful recurving petals, giving a beautiful lily-like effect 


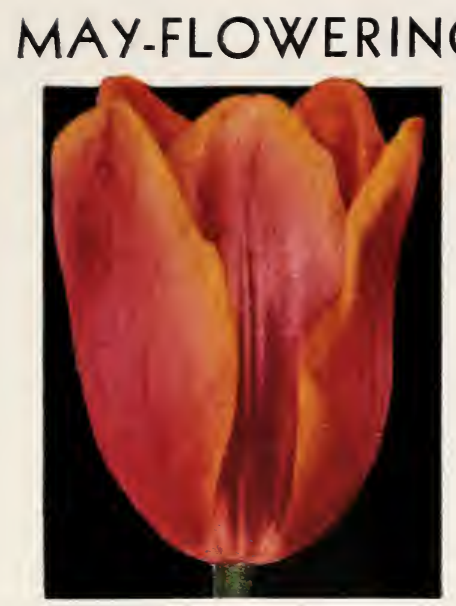

\section{COTTAGE TULIPS}

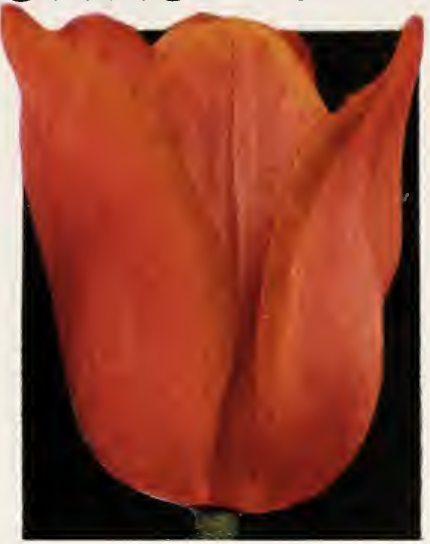

Dido
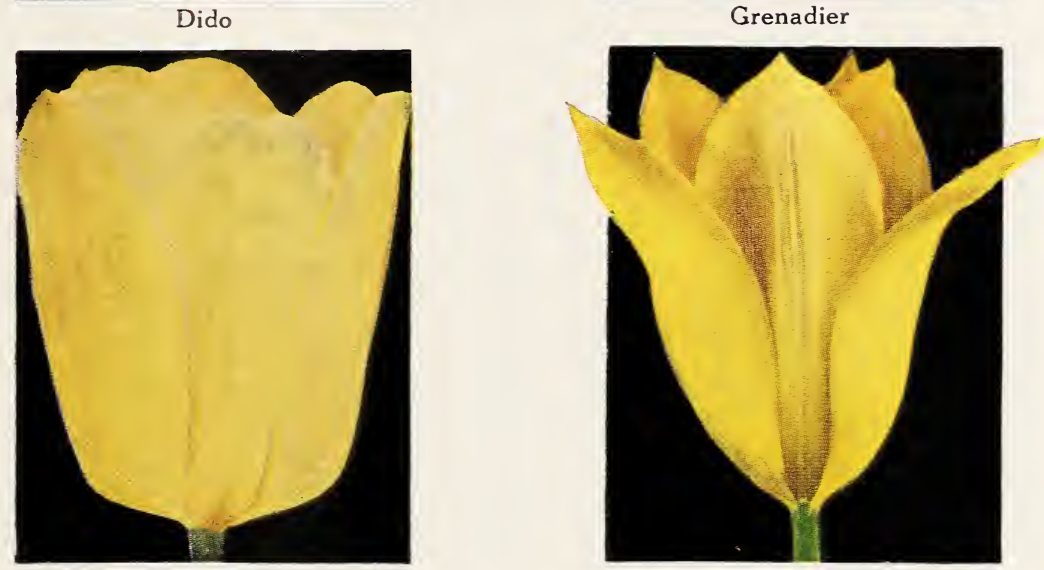

Inglescombe Yellow

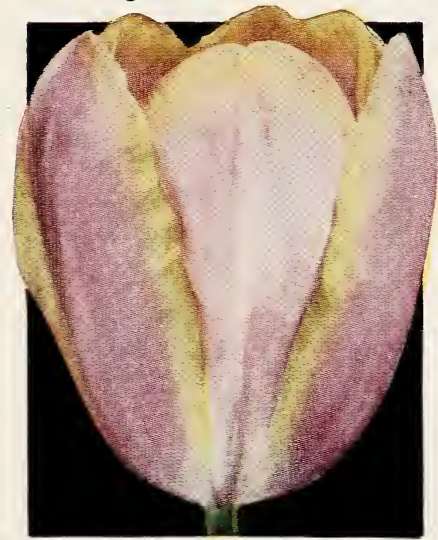

John Ruskin

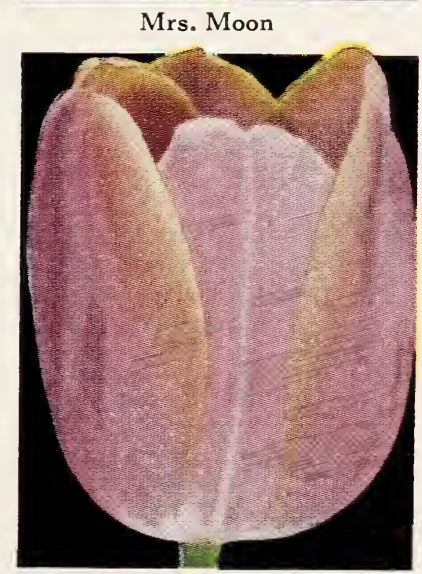

Inglescombe Pink

SPECIAL AMATEURS' COLLECTION

Six (6) each of above six varieties. . \$2 75 Twelve (12) each of above six varieties . .\$5 00 Twentr-five 25 ) each of above six varieties ...\$9 00

Packed and labeled separately. Sent prepaid to any address east of the Mississippi for cash with order 


\section{William M. Hunt \& Company}

\section{COTTAGE TULIPS, continued}

Rosabella. 20 in. Exquisitely shaped flowers of heavy substance, pale shell-pink with a creamy suffusion, sometimes stained dark rose on the center of the outside petals, with an occasional flame of scarlet on the inner petals, becoming rosy pink with age. The central base is very large and pure creamy white, and the anthers glittering black. An extraordinarily handsome Tulip of delightful shape and color . . . . .

Sir Harry. 22 in. Clear lavender-pink as seen in the rarest Cattleya orchids. Beautifully modeled cup, pointed and yet open, showing a lovely base of yellow and blue. At times the petals reflect a pearl-like luster. Fine size and good foliage . . . .

Snowdon. 26 in. Pure white flower of fine shape and great size. Recommended for both forcing and bedding : . . . . . The Fawn. 20 in. Lilac-white, flushed and veined soft rosy
fawn. Globular-shaped flower. Very fine variety for bedding.

Themis. 28 in. Pure white flower of ideal shape and size. Suitable for forcing and bedding . . . . . . . . . . . .

Twilight. 22 in. Pale violet-mauve with brown edge, striped dark violet; white base with blue halo . . . . . . . . . .

Union Jack (Distinction). 22 in. Heliotrope-violet, feathered deep purple with a few markings of white . . . . . . . .

Vindictive. 24 in. Fiery red with dark orange shadings . . .

Vitellina. 20 in. Cream-yellow, changing to amber-white as the flower ages .......... . . . . . . .

Walter T. Ware. $18 \mathrm{in.} \mathrm{Deep} \mathrm{golden} \mathrm{yellow.} \mathrm{One} \mathrm{of} \mathrm{the} \mathrm{best} \mathrm{of}$ its color among the Iate Tulips . . . . . . . . . . . . . . . . . .

MAY-FLOWERING TULIPS MIXED. A well-balanced mixture of all the foregoing varieties. Very suitable for bedding and cut-flowers

Special Amateurs' Collections. 250 Cottage or May-flowering Tulips in 10 distinct Special Amateurs Collections. and separate varieties, our selection, for \$12.50; 100 Cottage or May-flowering Tulips in 10 distinct and separate varieties, our selection, for $\$ 5.50$. Sent prepaid to any address east of the Mississippi for cash with order.

\section{Lily-flowered Tulips (May-flowering)}

This handsome and distinct new race of Tulips has been obtained by crossing Tulipa retroflexa with a pink Darwin variety, and the result is a sturdy-growing form with large, substantial flowers that still retain the form and elegance of Retroflexa, all segments reflexing a little at the tips. Certain of the finer Cottage Tulips, like Grenadier, Miss EIlen Willmott, Picotee, etc., really belong to this group.

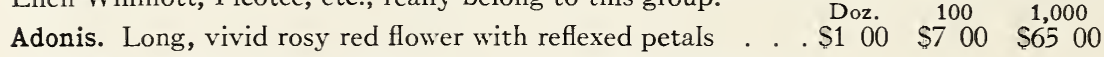

Artemis. Long-stemmed; elegantly reflexed petals; bright carmine-rose, with pure white base . . . . . . . . . . . .

Fulgens. Rich deep crimson. Very attractive . . . . . . . 125

Marvel. Very distinct, sweet-scented variety. Inside old-gold, outside salmon-rose, edged yellow . . . . . . . . .

Sirene. 20 in. Superb example of the Lily-flowered type, and a beautifuI addition to our list of outstanding varieties. Wonderful cherry-rose on large, pure white base. Resilient stems. Its fascinating form has won many awards. Splendid for March forcing ................. 100

Solfatare. Pale primrose with long, reflexing petals. Very distinct. $100 \quad 700 \quad 6500$ COLLECTION: One dozen each of the above 6 varieties for $\$ 5.50$. Sent prepaid for cash with order 


\section{Breeder Tulips in Tints and Tones of Royal Loveliness}

These are the old Dutch self-colored Tulips, neglected for many years, which modern taste for unusual colors has called into prominence once more. Nature's happiest colorcombinations of purple and bronze, gray and lilac, brown and orange, are revealed to us in this group. The flowers are mostly large, of perfect form, and are borne on taII, strong stems. They may be successfully brought into bloom in the greenhouse by the first week of April. In the garden they combine weIl with the Darwins, and, except in range of color, are indistinguishable from them.

Annie McGregor. 24 in. Deep rose with white base. Fine for Doz. planting in borders............. . $\$ 150$

100

$\$ 1000$

Attraction. 26 in. Bluish violet-purple outside, glowing purple inside; white base . . . . . . . . . . . . . . .

Bacchus. 32 in. Deep violet-blue, with darker bloom; inside light violet-blue, with white star at base . . . . . . . . .

Bronze Queen (Clio; Biscuit). 28 in. Buff-yellow, inside shaded golden bronze; yellow base. For borders, and a good forcer

Cardinal Manning (Goliath; Kingscourt). 28 in. Claret, flushed rosy bronze, changing to rosy violet . . . . . . . . . . .

$\begin{array}{llllll}150 & 9 & 00 & \$ 80 & 00\end{array}$

$100 \quad 700 \quad 6500$

$75 \quad 500 \quad 4500$

$100 \quad 550 \quad 5000$

Cherbourg. 32 in. A recent introduction of superlative form. Deep golden yellow flowers are tinted with bronzy lilac and brown. They are produced on strong, long stems and make a wonderful effect when massed for bedding. We have only a limited stock of this variety . . . . . . . \$2 each . 19

Copernicus. $24 \mathrm{in}$. The flowers are dark coppery bronze shaded with old-rose.

Creation. 28 in. A very large flower of deep golden bronze, margined with orange. Its hitherto high price has somewhat retarded its sale, but we are now enabled to offer this at a very low price

6000

Dom Pedro. 24 in. Deep coffee-brown, with margin of golden brown outside, the turned petal showing a yellow and olive base, with overtones of bright mahogany. No flower succeeds in creating a similar symphony in related hues. It is unique, moreover, very fragrant and of a large, beautifully rounded form. Interesting vase Tulip on account of its color and delicate fragrance

Feu Ardent. 26 in. Crimson-red, shaded mahogany. A brilliant flower with yellow base . . . . . . . . . . . . .

Garibaldi. 32 in. One of the finest Breeder Tulips ever offered. Lilac-bronze, edged primrose-yeIlow. Beautifully shaped flower borne on long stem . . . . . . . . . . . . . .

Godet Parfait. 30 in. Large flower of attractive color-dark plum-violet, with white base and blue halo .

Golden Bronze. 25 in. Outside distinctly old-gold, with a shading of Iavender, rising from the base nearly to the tips of the petals; inside silky brown, shading to golden bronze; Iovely yellow center 


\section{BREEDER TULIPS}

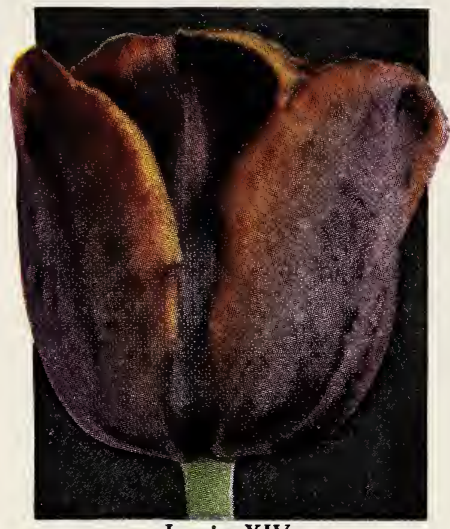

Louis XIV

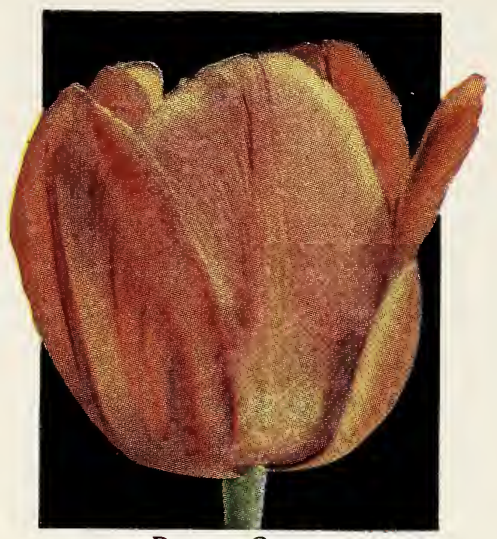

Bronze Queen

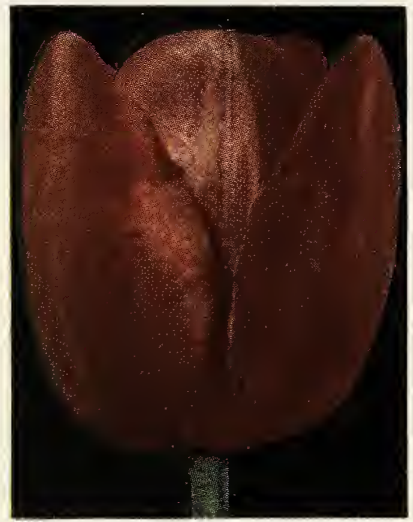

Dom Pedro

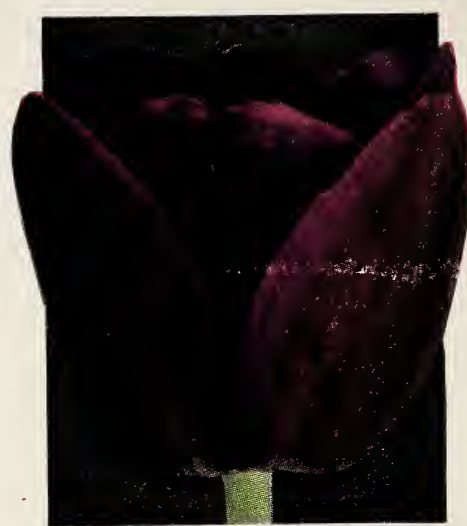

Godet Parfait

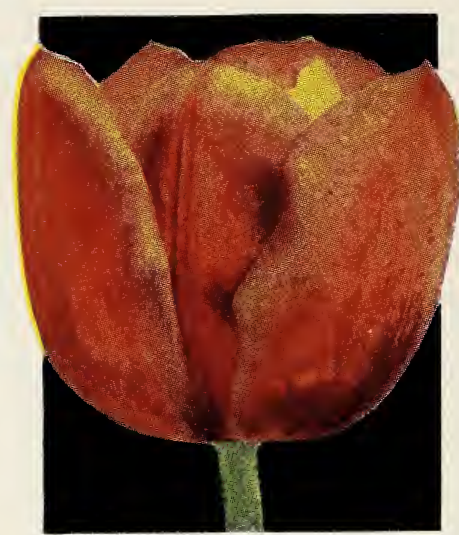

Golden Bronze

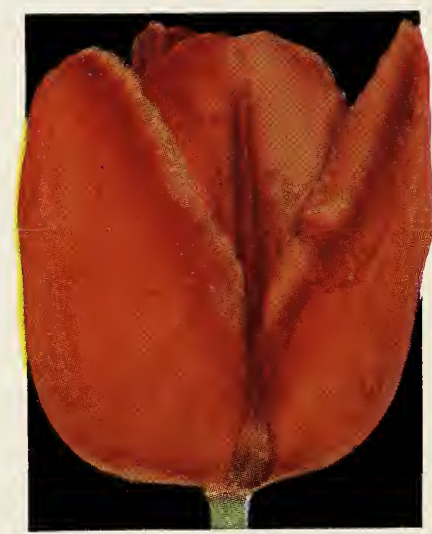

Prince of Orange

SPECIAL AMATEURS' COLLECTION

Six (6) each of above six varieties. . \$2 50 Twelve (12) each of above six varieties . $\$ 475$ Twenty-five (25) each of above six varieties . . . \$800 Packed and labeled separately. Sent prepaid to any address east of the Mississippi for cash with order 


\section{Hunt's PERFECTION Bulbs}

\section{BREEDER TULIPS, continued}

Goldfinch. $30 \mathrm{in.}$ Only in Brecder Tulips can one find such golden tints of fine tortoise, luminous yellows, and warm browns in happy harmony. We selected Goldfinch as our very best offering in this color. A gracefully formed Tulip which will grow well in every position, admired wherever placed. Rather scarce and a privileged listing by us

Doz.

Gold Heart. Breeder Tulips. Produces a Iarge, well-shaped flower of deep brown, shaded with gold

Indian Chief. 34 in. Coppery red, flushed purple. Long and artistic flower carried on long, strong stem . . . . . . . .

James Watt. 26 in. Deep violet, flushed bronze; inside dark mahogany, shaded brown

Jaune d'CEuf (Sunrise). 26 in. Coppery yellow, with broad stripe of lilac; inside bronze-y ellow, with dark green center. A splendid variety for forcing and fine for borders . . . . .

La Turquoise. 26 in. An unusual color-combination-brownish violet, with broad yellow edge. Handsome shaped flower

Louis XIV. 32 in. A royal Tulip. Purple, edged golden bronze; extra-fine, globular flower

Marechal Victor. 29 in. Clear lavender-blue, with broad margin of bronzy buff; Iarge yellow base edged green

Marie Louise. 24 in. Old-rose, flushed salmon-orange; yellow base streaked olive

Medea. 30 in. Crushed strawberry, shaded heliotrope; yellow center. Large flower

Mrs. Beecher Stowe. 26 in. Clear deep blue, uniform in color. Good form and splendid stem

Panorama. 26 in. Warm terra-cotta with reddish mahogenya quiet, even tone which covers the huge goblets entirely. The large petals are curved in at the top, so that even on very bright days the flower appears as if closed. A look inside is rewarded by a display of scintillating orange-mahogany on an olive-green base. Easy forcing tendency

Prince Albert (Alice). 30 in. Warm ochre-brown, with purplish flush through center of petals; green base . . . . . . . . open petals warm orange on yellow base, frgured with black arrows. Cups elongated, filled with abundant perfume. Ideal Tulip for massed beds and solid border plantings . . . . .

St. James. 26 in. Dark lilac, shot through with deep purple and brown tones which lighten up at the edges of the petals to a bronze-brown-tints of gorgeous dark brocade. Rather open, pointed petal form, permitting a glimpse of the brighter coloring inside the cup. A reasonably priced variety of great interest

Sundance. $28 \mathrm{in}$. One of the best of last season's novelties. Flowers are beautiful orange, flushed bronze, with lighter bronze edge. A large and strong-growing variety . . . . .

Turenne (Macmahon). $30 \mathrm{in.} \mathrm{Soft} \mathrm{purplish} \mathrm{brown;} \mathrm{outer} \mathrm{petals}$ shaded heliotrope, with broad margin of amber-yellow; yellow base . 


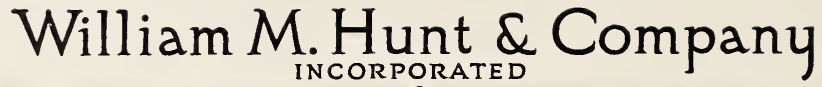

\section{BREEDER TULIPS, continued}

Velvet King. 26 in. Strong violet-purple of a nice, even tone; inside much brighter; base passing from blue into white.

Doz.

100

1,000 Often possesses an additional petal, and when particularly happy in a preferred position, the plant develops an extra flower from the upper leaf-base. Very sturdy

Yellow Perfection (OId Gold). 26 in. Coppery yellow, with edges of softer tone; inside coppery brown; yellow base, starred green . . . . . . . . . . . rieties. For massing and bedding . . . . . . . . . . .

Special Amateurs' Collection: 150 Breeder Tulips in 10 distinct and separate varieties, our selection, for $\$ 9$. Sent prepaid to any address east of the Mississippi for cash with order.

\section{The Mendel Tulips \\ A NEW EARLY-FLOWERING RACE OF DARWINS}

By crossing the Darwins with the oId-fashioned early Duc Van Thol Tulip, this new race has been produced, carrying the stem, size, color, and shape of the Darwins, with the early blooming properties of the other parent.

Each Doz. 100

Alsace. 24 in. Bright rosy carmine with white center ... . $\quad \$ 200 \quad \$ 1500$

Early Beauty. 22 in. A very fine shade of rosy pink . . . . . \$0 $50 \quad 350 \quad 2400$

Early Wonder. 24 in. Lilac-rose. Very tall . . . . . . . . . $50 \quad 5502400$

Favorite. 22 in. Vivid rose . . . . . . . . . . . . 503752600

Fiery Diamond. 20 in. Bright vermilion-red. . . . . . . . . . 503502400

Liberty. 26 in. Very large; cerise-red . . . . . . . . . . . 1501500

Ovidius. 26 in. Large; carmine-rose . . . . . . . . . . . . $75 \quad 6505000$

Paula. 23 in. Vivid carmine-rose . . . . . . . . . . . 7565505000

Zenober. 22 in. Cochineal-red ............ . 6055504000

MIXTURE. Splendid mixture of Mendel Tulips . . . . . $100 \quad 550$

\section{Triumph Tulips}

Triumph Tulips are hybrids of the Darwins, with the same strong stems and stately stature, of unusually attractive self colors and delicate blendings. They bloom two to three weeks earlier than their parents.

Each Doz. 100

Algiba. 24 in. Splendid shade of bluish mauve, slightly towards

the end-a splendid color . . . . . . . . . . . . \$0 $30 \quad \$ 200 \quad \$ 1500$

Florida. 26 in. Enormous, rich carmine-red flower . . . . . . $60 \quad 60504000$

J. S. Bach. 26 in. Deep red with narrow white edge . . . . . $35 \quad 3501800$

Lord Carnarvon. 24 in. Large, lily-like, pointed flower with rich wine-colored petals, broadly margined with white, which gradually deepens to old-rose-pink; white base and yellow anthers. On opening it resembles the early Tulip, L'Esperance.

Mr. Zimmerman. $24 \mathrm{in}$. This is a conspicuous deep rose-pink. Produces an extremely large flower of wonderful substance on Iong, strong stems . . . . . . . . . . . . . . .

Pollux. 22 in. A very rich magenta-purple; very large . . . .

Sagittarius. $26 \mathrm{in.}$ White, turning to very soft pink at top of petals; very large. Extremely tall . . . . . . . . . .

Tucana. 24 in. Light orange, shaded carmine-a splendid color .

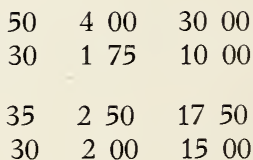




\section{Hunt's PERFECTION Bulbs}

\section{Rembrandt Tulips}

These are Darwins in size, shape, and stature, but the colors are in flakes or "feathers" sometimes flame-shaped and always attract favorable attention.

Doz. $\quad 100$

Apollo. Rosy lilac and white, with deep crimson markings . . . . . . \$1 $25 \$ 750$

Butterfly. Soft lilac, with deep carmine stripe . . . . . . . . . . . 100700

Hebe. Pale lilac-white, splashed deep brown . . . . . . . . . . . . 100700

Red Prince. Fiery red flames on rosy ground. One of the best Rembrandts $\begin{array}{llll}1 & 00 & 700\end{array}$

Rosy Gem. Rosy lilac and white, with deep red markings . . . . . . 125750

Salome. Carmine-rose, with white markings. Very fine . . . . . . . $150 \quad 900$

Victor Hugo. Scarlet and white . . . . . . . . . . . . . 100700

MIXTURE. AII the above varieties . . . . . . . . . . . . . . . . 100600

Collection of Rembrandt Tulips, 12 each of 7 varieties, for $\$ 7.50$, postpaid

\section{Bybloem and Bizarre Tulips}

These Tulips are an old race which has been grown in France and Holland for many years. Bybloem Tulips are striped and feathered rose or violet on a white ground. The Bizarre Tulips have dark brown stripes and feathering on a yellow ground. While not growing so tall as the Breeder and Darwin Tulips, they flower at the same time, and they are very useful for planting in the herbaceous border, etc.

Bizarre, Mixed. An excellent mix-

ture of the choicest named sorts. $\$ 100 \quad \$ 5 \quad 50$

Rose Bybloem, Mixed .. . . 100600

Violet Bybloem, Mixed . . . . 100600

\section{Parrot Tulips}

Very large varieties with drooping, parrot-like buds and wide-spreading, fringed and frilled petals with curious markings. Unusual and striking as cut-flowers but not good for bedding or mass display.

Admiral of Constantinople.

Red and orange... \$0 $75 \$ 500 \$ 4500$

Cramoisi Brillant. Brilliant

crimson . . . . . . $75 \quad 500 \quad 4500$

FANTASY. Large, exquisitely handsome flowers of flesh-pink, salmon, and rose-color, with deeply fringed and fantastically frilled petals. The stems are taII, strong, and hold the flowers erect. Considered the handsomest and most desirable of the Doz. 100

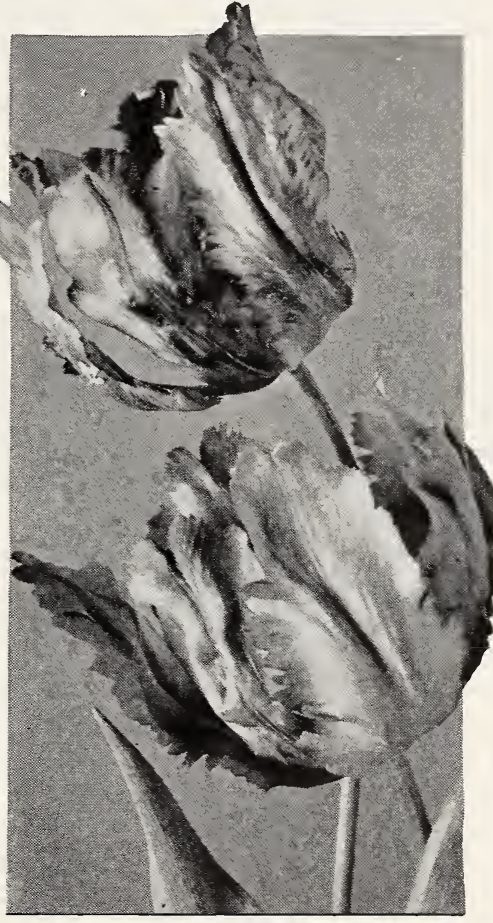

Parrot Tulip Parrot class ................ . $\$ 400 \$ 3000$

Lady Derby. 28 in. Variety with pink and white edges and unusual blue-green markings. A very attractive novelty in this class of Tulips ......... . \$2.50 each . 2500

Lutea Major. Yellow, with crimson and green stripes . . . . 73

Perfecta. Bright yellow, scarlet and green . . . . . . . . . 75

$500 \$ 4500$

SPLENDID MIXTURE. AII the above varieties 


\section{William M. Hunt $\underset{\text { incorporATED }}{\&}$ Company}

\section{Single Early Tulips}

The old-fashioned Single Early Tulips are unsurpassed for bedding and, with few exceptions, excellent for forcing. Gardeners are learning that the wholesale discarding of this class, which took place a few years back, was a mistake. The monotony of the solid beds of red and yellow, and the acres of Keizerskroon which used to make our parks and gardens offensive, will never return, but such lovely things as De Wet, Lady Boreel, Pink Beauty, President Lincoln, and Rose Luisante are indispensable in any weIlplanned garden. Blooming with the narcissus, at a time when bright color is sorely needed, they are treasures indeed. And the handsome thing about them is that they are gone by the time the space is needed for annuals and bedding plants, so that there is no blank interval in the effective use of the ground. The following are the cream of the best varieties.

Belle Alliance (Waterloo). 15 in. Cherry-red of blazing bril- Doz. $100 \quad 1,000$ liance, with a dazzling yellow center. One of the brightest and most graceful early varieties. Very good for forcing and bedding

Brilliant Star. 12 in. Scarlet, with black center. Early . . . . $75 \quad 500$

Chrysolora. $14 \mathrm{in}$. Golden yellow flowers of large size and fine form. One of the very best cheaper varieties in this color. Splendid for planting outside...
Duchesse de Parme. 15 in. Dull blood-red, edged deep yellow. Excellent for bedding

Fred Moore. 15 in. Apricot-brown, shaded at edges of petals to duII orange-yellow. Early forcing

General de Wet. See page 19.

Golden Brilliant. 16 in. A beautiful golden yellow sport of Cramoisi Brillant. Undoubtedly one of the finest early yellow

Tulips for forcing . . . . . . . . . . . . . improvement on the well-known Flamingo, but of a deeper color

Keizerskroon (Grand Duc). 16 in. Bright crimson-scarlet, edged golden yellow. For bedding and forcing

King of the Yellows. 12 in. Lemon-yellow. Early. Very handsome for cutting

\section{(1)}

Lady Boreel. 11 in. Snow-white, large, long flower. Best white for beds. A sport of Joost Van den Vondel

Mon Tresor. 12 in. Pure yellow. The best yellow Tulip for early forcing . . . . . . . . . . . .

Pink Beauty. 13 in. Very lovely flower with deep ovoid petals. The three inner petals are brilliant scarlet-pink and the three outer ones are bordered with the same color, leaving a long, triangular white center running to a point at the tip, so that the flower, on the outside, appears to have scarlet and white in broad stripes. The base of the flower is white, with an intense yellow center and orange-yellow anthers. This is one of the handsomest Tulips in any class. No Darwin variety can approach it in brilliance and sheer loveliness . . . . . . .

Pink Delight. $14 \mathrm{in.}$ Deep rosy pink. Very large and distinct flower of globular shape . . . . . . . . . . . . . .

$\begin{array}{llllll}125 & 800 \quad 7500\end{array}$

President Lincoln. 14 in. A charming Tulip of soft magentaviolet. An unusual color in this class, and excellent for bedding in close connection with pale yellow narcissus which bloom at the same time 


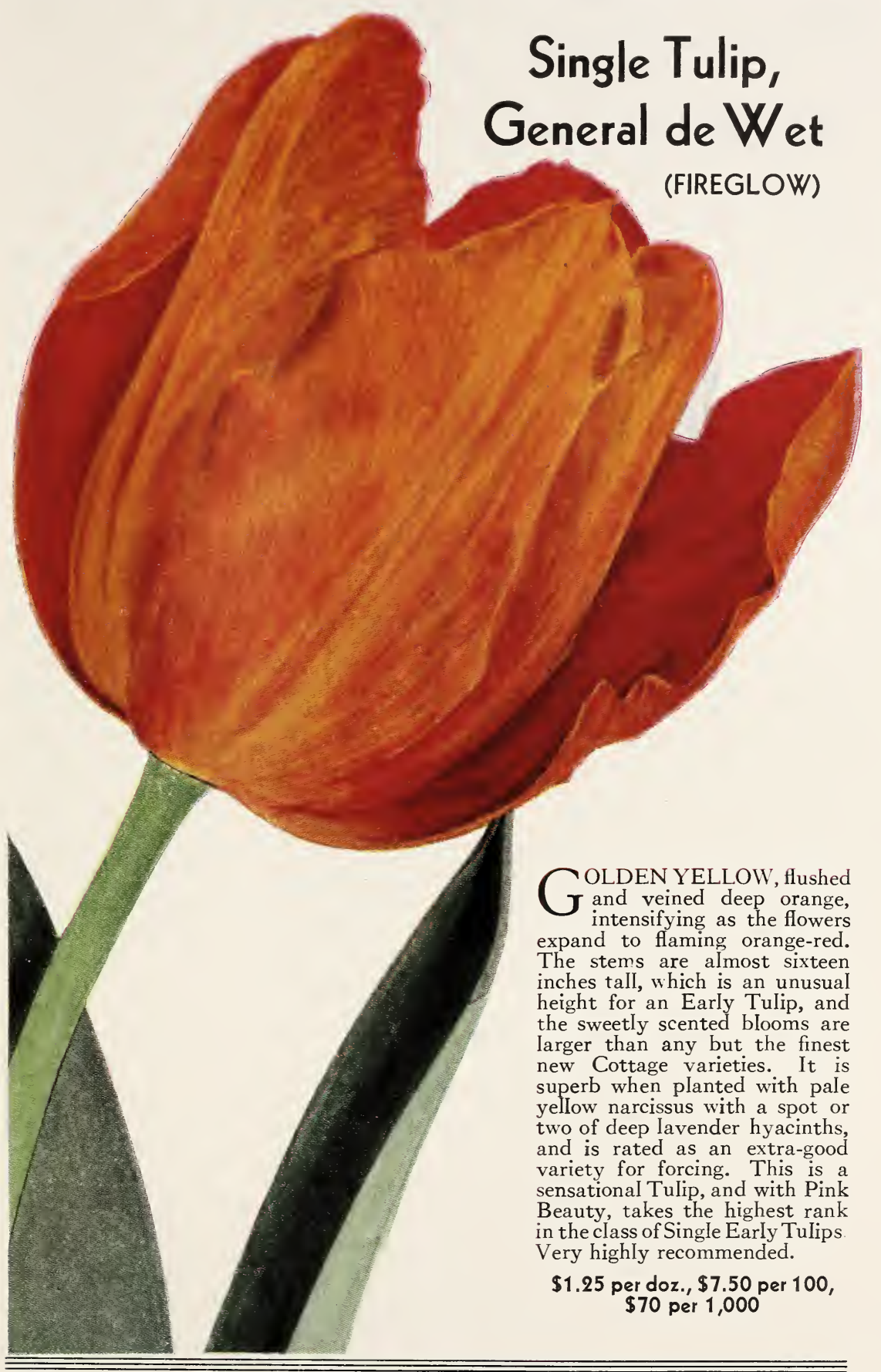




\section{William $M$ IN Hunt $\underset{\text { IN ORPATED }}{\mathcal{E}}$ Company}

\section{SINGLE EARLY TULIPS, continued}

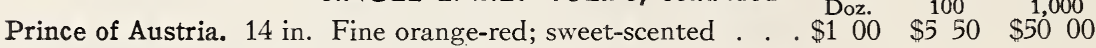

Proserpine. $14 \mathrm{in}$. Claret-red. The earliest variety for forcing and also excellent for bedding . . . . . . . . . . . . .

Rising Sun. 16 in. Deep golden yellow. Excellent bedder. A sport of the old Duchesse de Parme . . . . . . . . . .

Rose Luisante. 14 in. Brilliant deep rose-pink. Superb for bedding or late forcing. . . . . . . . . . . . . . . . . . .

Van der Neer. 12 in. Intense violet-rose, or rose-purple. Extremely handsome silky flower of large size and perfect shape

Vermillon Brillant. 13 in. Vermilion-red. Extra good for early forcing . . . . . . . . . . . . . . . . . . .

White Beauty (Albion), 13 in. A greatly improved form of $\mathrm{La}$

Reine. Pure white. Extra early . . . . . . . . . . . . .
Yellow Prince (Golden Prince). 13 in. Chrome-yellow, streaked with dull red, deepens with age; sweet-scented. The most popular yellow . . . . . . . . . . . . . . . .

EARLY TULIPS MIXED. A fine selection of all the above varieties. Splendid and economical for cutting

$100 \quad 650 \quad 6000$

$\begin{array}{llllll}1 & 00 & .6 & 00 & 5500\end{array}$

$100 \quad 600 \quad 5500$

$\begin{array}{llllll}125 & 750 & 70 & 00\end{array}$

$100 \quad 550 \quad 5000$

$\begin{array}{llllll}125 & 750 & 70 & 00\end{array}$

$100 \quad 550 \quad 5000$

$75 \quad 450 \quad 4000$

\section{Double Early Tulips}

Very showy and lasting; splendid for beds and borders and for culture in pots. Double Early Tulips have been much maligned but for long-lasting color early in the season, nothing is better, and some of the best have really lovely form.

Boule de Neige. 12 in. Sulphury white, enormous, double flow- Doz. $100 \quad 1,000$ er, resembling a white peony. Extra-good bedder and forcer. $\begin{array}{llllll}\$ 1 & 00 & \$ 5 & 50 & \$ 50 & 00\end{array}$

E1 Toreador. 13 in. Raspberry-red, edged buff-yellow-splendid color. Attractive for forcing or bedding . . . . . . . . . .

Golden King. 13 in. Soft canary-yellow, shaded deeper yellow, Large and handsome. For bedding . . . . . . . . . .

Imperator Rubrorum. 14 in. Blood-red. Recommended for forcing and a good bedder . . . . . . . . . . . .

Marechal Niel. 11 in. Canary-yellow, flushed with orangea very striking color. Splendid for both outdoor planting and forcing . . . . . . . . . . . . . . . . . . . . . . . .

Mr. Van der Hoef. 12 in. Deep pure yellow. The best of its color. Extra-good bedder and forcer . . . . . . . . . . .

Murillo. 12 in. White flower with delicate rose-pink flush. The petals are symmetrically arranged, so that it resembles a small, loose-flowered peony. Lasts a long time in the garden and is most delightful. The best double for forcing or bedding . .

Orange Nassau. 11 in. Bright orange-red novelty. Recommended for planting in beds, setting out, or grouping borders .

Peach Blossom. 12 in. Bright rose-pink, flushed white. Large, double flower and very handsome color. A sport of the wellknown Murillo

Rose d'Amour. 12 in. Very soft rose, deepening with age to peach-blossom-rose. A beautifully shaped flower and a very lovely color. Very good bedder 


\section{Hunt's PERFECTION Bulbs}

\section{DOUBLE EARLY TULIPS, continued}

Schoonoord. $12 \mathrm{in.} \mathrm{A} \mathrm{cream-white} \mathrm{sport} \mathrm{of} \mathrm{Murillo.} \mathrm{Extra} \mathrm{good} \mathrm{Doz.} 100$ for forcing and bedding. . . . . . . . . . $\$ 100 \quad \$ 550 \quad \$ 5000$

Tea-rose (Safrano; Brimstone Beauty). 12 in. Soft pale yellow, beautifully tinged flesh-rose as the flower ages. Very good bedder and splendid forcer : . . . . . . . .

Tournesol Red and Yellow. 11 in. Red, tinged deep orangeyellow. Very early forcing variety Vuurbaak. $12 \mathrm{in.}$ Fiery vermilion-red, shaded orange when fully
opened. For beds and good for late forcing . . . . . 100

\section{Ground-Covers and Companion Flowers for Bedding with Tulips and Other Bulbs}

Forget-me-nots (Myosotis). Exquisite as an underplanting for pink, Doz. 100 white, and pale yellow tulips, and a good ground-cover after they have gone .. . . . . . . . . . . . . . \$3 00

Mertensia virginica (Bluebells). Lovely clusters of drooping, pale blue bells. Fine with light pink or pale yellow tulips and daffodils .

Rock Cress (Arabis alpina). Pure white flowers in solid drifts-fine with daffodils and early tulips. Blooms too early to work well with Darwins and Breeders .

Veronica repens. A dense, carpet-like plant covered in Iate tulip-time with tiny points of brilliant blue. Wonderful little ground-cover and spreads rapidly .

Viola cornuta (The Horned Pansy). Exquisite, graceful flowers like large violets, in many colors. Combines well with tulips of all shades .

\section{Botanical Tulips}

Plant in generous clumps in good soil, preferably at the base of a fairly large sheltering rock, which will serve both as protection and as a background when they are in flower. Clusiana. 12 in. Carmine-rose, with white edge. It is sometimes Doz.
known as the "Candy-stick" Tulip because of its delicately red-and-white striped effect when partly open . . . . . . \$1 00

100

1,000

Cornuta stenopetala. $10 \mathrm{in}$. Crimson, with points of petals rich yellow

Eichleri. 11 in. Large; brilliant scarlet, with black center. A handsome, permanent variety of highest class

Florentina sylvestris. 18 in. Produces fragrant yellow blooms, sometimes two on a stem. This variety increases yearly when acclimated . . . . . . . . . . . . 100

Fosteriana. 12 in. Very large; brilliant red . . . .\$1.50 each . 1650

Greigi. 9 in. Fiery orange-red. The foliage is most peculiarly

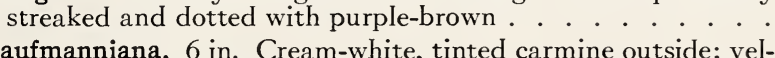

Kaufmanniana. 6 in. Cream-white, tinted carmine outside; yel-
Iow center. The earliest variety and more beautiful than many late garden varieties

Marjoletti. 10 in. Cream-color with red margin . . . . . . . 125

Micheliana. 9 in. Red with very large black center ... . .

Præstans, Tall. $10 \mathrm{in.} \mathrm{An} \mathrm{attractive} \mathrm{orange-red} \mathrm{Tulip} \mathrm{that} \mathrm{often}$ bears four or five flowers on a stem . . . . . . . . 1000

Præstans, Dwarf. 7 in. Blooms scarlet-red. Earlier than preceding . . . . . . . . . . . . 


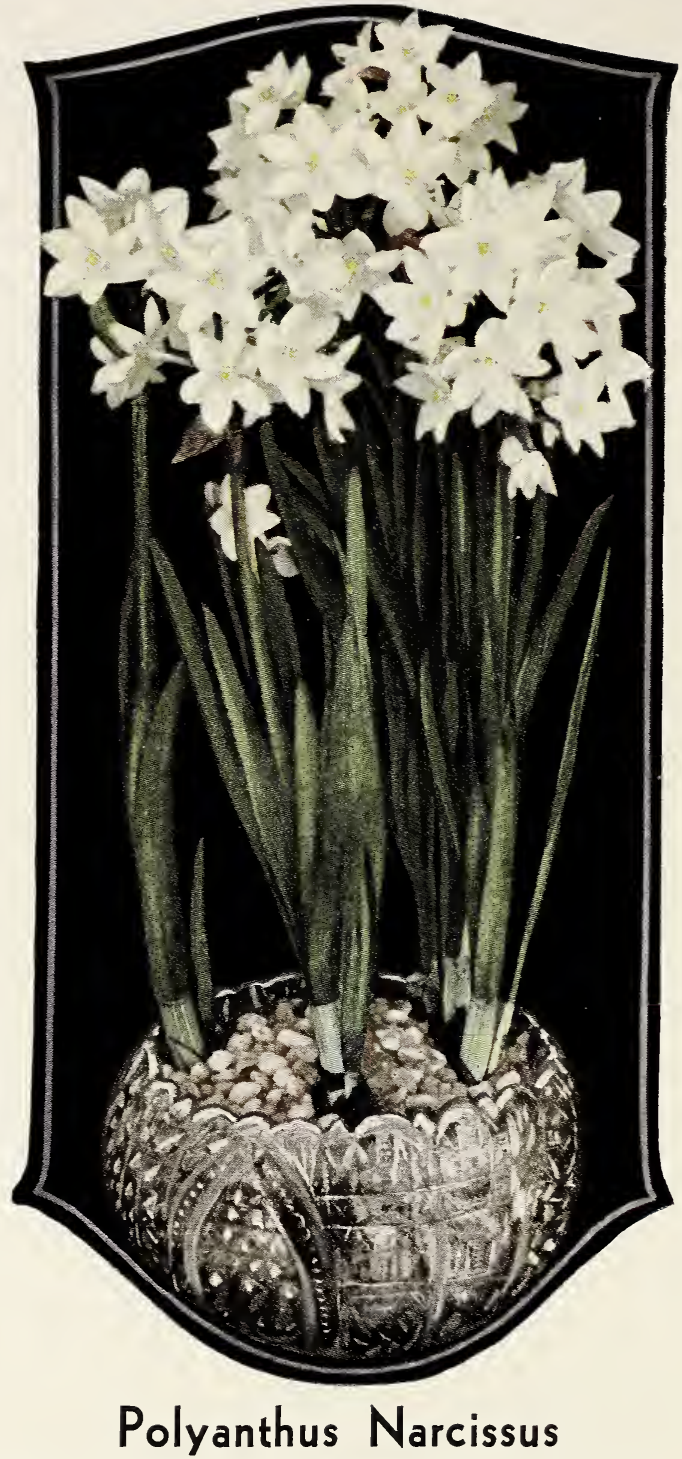

Paper-White. Kept a few weeks in the dark after setting, to de- Doz. velop root-action, then brought to a light, airy room, temperature about 60 degrees, the white, fragrant trusses will open in about six to seven weeks.

Mammoth Bulbs. XXX .............. \$1 00 \$8 00 \$7500

Large Bulbs. XX . . . . . . . . . . . . . 10077507000

Gloriosa. Large; white with orange cup. Splendid variety for forcing. Large Bulbs . . . . . . . . . . . . . 175120011000

Soleil d'Or. Pale yellow perianth, orange cup; termed the "Yellow Paper-White."

Mammoth Bulbs. XXX . . . . . . . . . . . 250180017000

Large Bulbs. XX . . . . . . . . . . . . . . . . . . . 175140013500

Chinese Sacred Lilies. Produces flowers in clusters similar to those of the Paper-White Narcissus. Splendid in pots, bowls, soil or water with pebbles. They may be had in bloom in six to eight weeks' time...... $35 \mathrm{cts}$. each . 300 


\section{Hunt's PERFECTION Bulbs}

\section{Narcissus That Flower from March to May}

Narcissus, or Daffodils, vie with early tulips for popularity in spring gardens. They bloom from March into the middle of May. Many varieties may be forced in greenhouses or grown in pots or dishes in the home, for they are very easy to cultivate.

Æolus. (Trumpet-Bicolor.) Snow-white perianth; Iong yellow trumpet with beautifully frilled and recurved brim. Giant exhibition variety. Disseminators of this variety claim it to be the largest and most perfect Bicolor in existence today . \$7 00

Doz. $\quad 100 \quad 1,000$

Albatross. (Barri.) Perianth white; pale lemon cup frilled orange-red

$150 \quad 1000 \quad \$ 9000$

Autocrat. (Incomparabilis.) Clear golden yellow, with broad perianth. Small flowers but very fine variety for the border or in pots

Barri Conspicuus. (Barri.) Straw-yellow perianth, with bright orange cup. Very free bloomer. Excellent for forcing . . .

Bath's Flame. (Barri.) Yellow perianth; deep yellow cup with broad edge of orange-red. Petals very long . . . . . .

Bernardino. (Incomparabilis.) Perianth creamy yellow; cup nicely frilled, and stained deep orange and apricot. A handsome addition to this class . . . . . . . . . . .

C. J. Backhouse. (Incomparabilis.) Yellow perianth; orangescarlet cup. Very sturdy and of great substance . . . . . with creamy perianth

Cheerfulness. (Poetaz.) Finest of the new double Poetaz. Cream and orange. Perfectly hardy . . . . . . . . . . .

Cleopatra. (Trumpet.) Very sturdy and of great substance. Perianth and trumpet deep yellow . . . . . . . . . . .

Crœsus. (Incomparabilis.) Round, imbricated primrose perianth of great size; widely expanded deep red crown. Show variety

Crystal Queen. (Leedsi.) Pure white perianth; pale primrose cup, passing to white. Flowers $3 \frac{1}{2}$ inches across . . . 400

Elvira. (Poetaz.) Pure white with yellow eye. Very large and free-flowering ...............

Emperor. (Trumpet.) Primrose perianth; golden yellow trumpet. Good forcer.

Mother Bulbs. XXX .... 300

First-size Bulbs. XX .......... . . 200

$200 \quad 1200 \quad 11000$

Empress. (Trumpet-Bicolor.) Sulphur-white perianth; chromeyellow trumpet. Very good for late forcing variety.

Mother Bulbs. XXX . . . . . . . . . . . 300

First-size Bulbs. XX . . . . . . . . 200

$\begin{array}{llll}18 & 00 & 170 & 00\end{array}$

$1300 \quad 12000$

Evangeline. (Leedsi.) Large, pure white perianth; soft lemon cup. Strong grower . . . . . . . . . . .

Firebrand. (Barri.) A combination of creamy white petals and glowing red, fluted cup 


\section{William M. Hunt $\underset{\text { INCORPORATED }}{\mathcal{E}}$ Company}

\section{NARCISSUS, continued}

Glory of Sassenheim. (Trumpet-Bicolor.) White perianth; gol- Doz. den yellow trumpet. Large flower of good substance . . \$2 50

$100 \quad 1,000$

Golden Frilled. (Incomparabilis.) Clearyellow, flat, overlapping perianth, with fine, frilled, widely expanded cup . . . $800 \quad 6000$

Golden Spur. (Trumpet.) Self-colored deep golden yellow. Well-known variety for early forcing.

Mother Bulbs. XXX . . . . . . . . . . . . . 300

First-size Bulbs. XX . . . . . . . . . . . . . . 200

$1700 \quad 16000$

$1400 \quad 13000$

Her Grace. (Leedsi.) Large silvery white flower of great substance and refined appearance; cup delicate sulphur-yellow, passing to white, deeply frilled at mouth. We rate this variety very highly .. . . . . . . . . . . . . . .

Homespun. (Incomparabilis.) Perianth soft pale yellow with finely expanded cup of same color . . . . . . . . .

Horace. (Poeticus.) White with conspicuous red eye. A splendid forcing variety

Imperator. (Trumpet.) The largest of all white Trumpets. Creamy white, with pure white perianth . . \$ \$4.50 each .

King Alfred. (Trumpet.) Golden yellow perianth and trumpet with deeply frilled mouth, elegantly recurved. Gigantic flower. Truly the King of Daffodils.

Mother Bulbs. XXX . . . . . . . . . . . . . 3502400

First-size Bulbs. XX . . . . . . . . . . . . . . . . 2501800

King George V. (Barri.) Broad, snow-white perianth with well-overlapping segments; large, flat yellow cup, with smaII red edge. . . . . . . . . . . . . . 300

Laurens Koster. (Poetaz.) Pure white perianth; Jarge orangeyellow cup . . . . . . . . . . . . . . . .

Lucifer. (Incomparabilis.) White perianth, with glowing orange-red cup. Very attractive . . . . . . . . . . .

Minister Talma. (Trumpet.) Handsome decorative Daffodil for the border or forcing. Flowers bright yellow, with large open trumpet, deeply frilled at brim . . . . . . . . .

Mme. de Graaff. (Trumpet.) Perianth pure white; trumpet very pale primrose, changing to pure white . . . . . .

Mrs. E. H. Krelage. (Trumpet-Bicolor.) Pure white perianth with light yellow trumpet changing to white as the flower develops. One of the best of this season's novelties . . .

Mrs. Langtry. (Leedsi.) Perianth white; cup white, primrose edge. Very free-flowering and showy . . . . . . . .

Olympia. (Trumpet.) Trumpet yellow; perianth of a slightly paler shade. This is a remarkably fine Daffodil. One of the best..................

Orange Cup. (Poetaz.) Creamy white with conspicuous orange cup-a most delightful color-combination . . . . . .

Ornatus. (Poeticus.) Pure white perianth; cup margined scarlet. Very early . . . . . . . . . . . . . . . . . .

Recurvus. (Poeticus.) Pure white perianth; deep orange-red cup . . . . . . . . . . . . . . . 

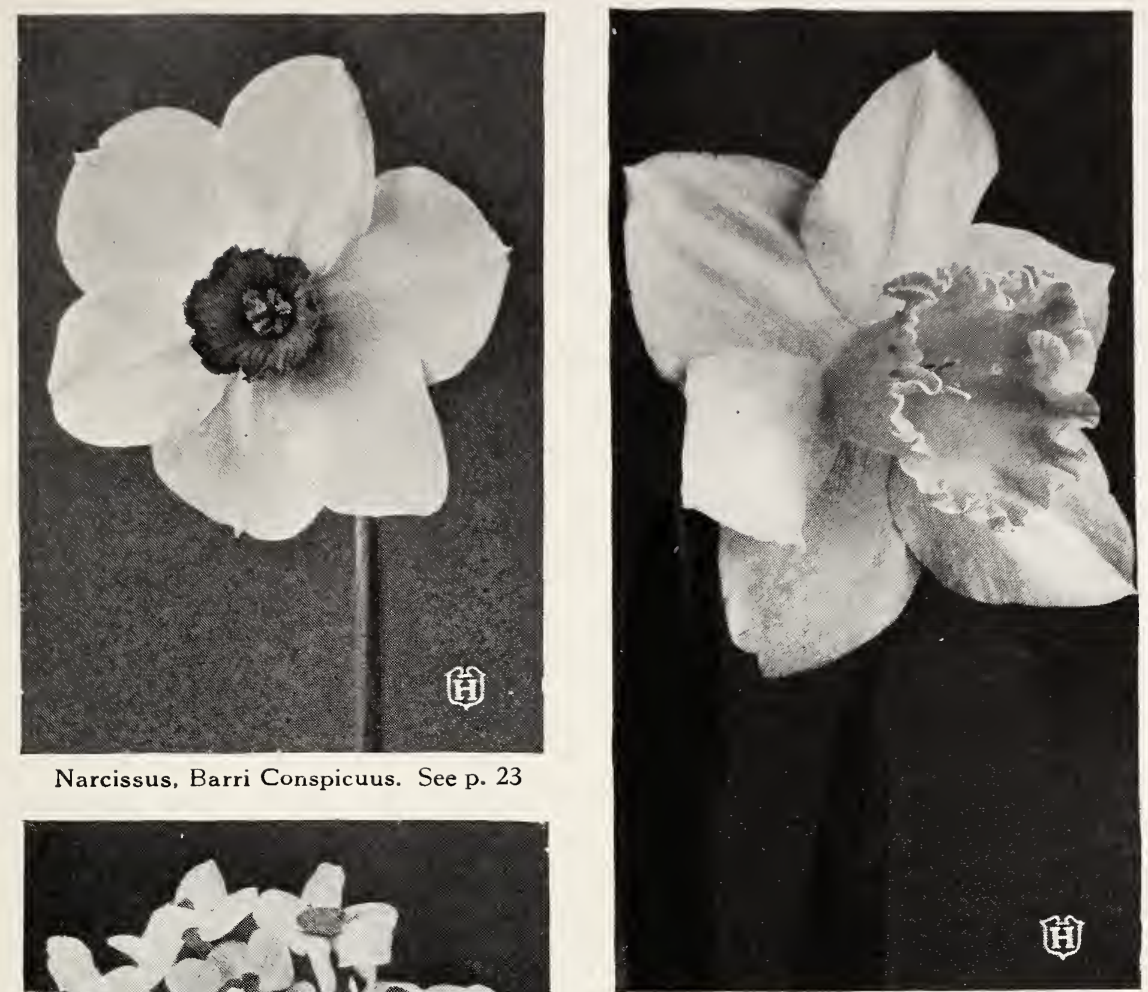

Narcissus, Barri Conspicuus. See p. 23

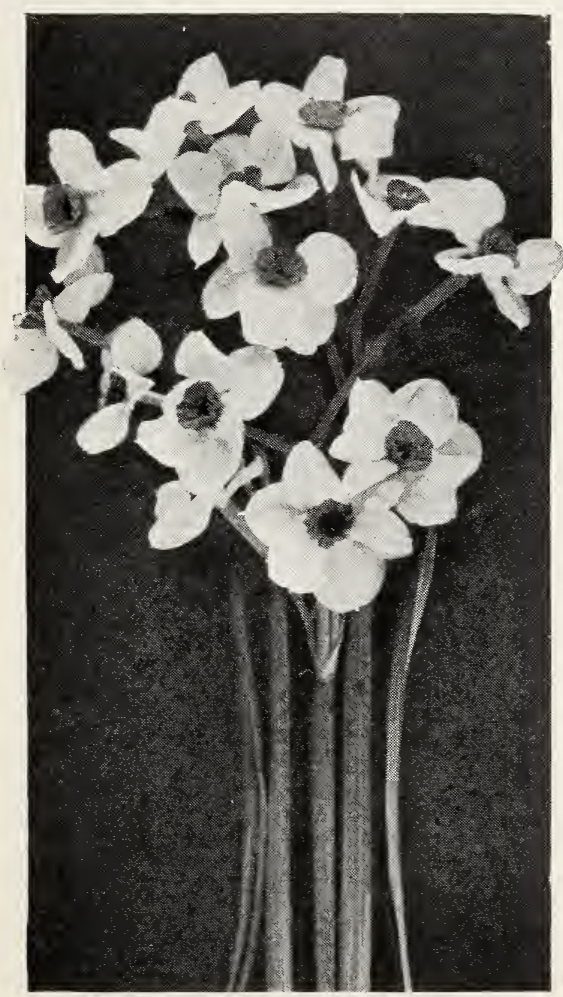

Narcissus, Laurens Koster. See p. 24

Narcissus, Her Grace. See p. 24

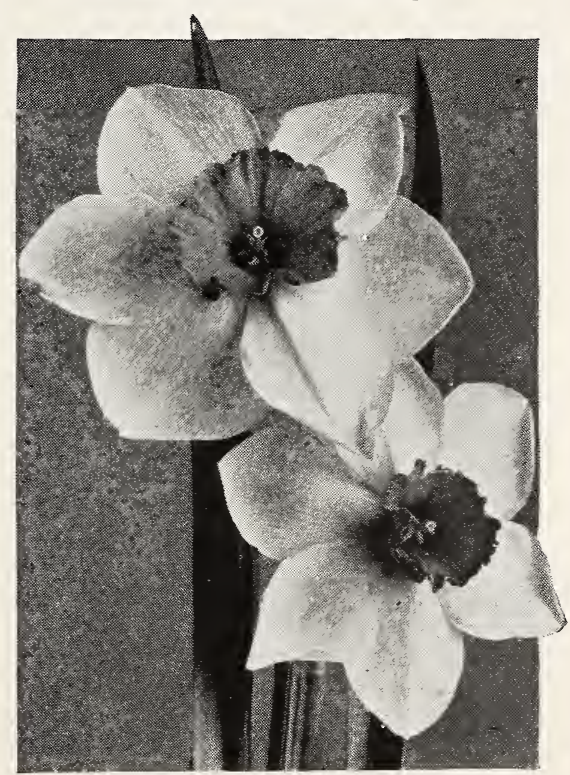

Narcissus, Whitewell. See p. 26 


\section{William M. Hunt $\underset{\text { INCORPORATED }}{\mathcal{E}}$ Company}

\section{NARCISSUS, continued}

Red Chief. (Barri.) Lovely flower; perianth pure white; flattish yellow crown with broad margin of fiery orange-red, and prettily fringed at edge ......... \$2 50

Red Star. (Incomparabilis.) White, wavy perianth; unusually

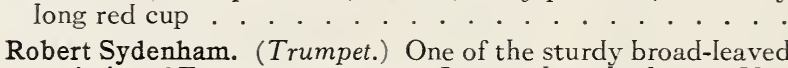
varieties of Emperor parentage. Larger than the famous Van Waveren's Giant. Very hardy. Easy to force into bloom about February 20. Strong bulbs produce two perfect flowers without fail. Petals sulphur-yellow; trumpet golden yellow .

Sea Gull. (Barri.) Large, spreading, pure white perianth; cup canary-yellow, edged apricot. Charming variety. . . . . .

Sir Watkin. (Incomparabilis.) Sulphur petaIs, with deep veIlow cup. Very handsome, large flower. First-size Bulbs. XX .

Southern Gem. (Leedsi.) A giant Leedsi with pure white petaIs and Iarge Iemon-yellow crown, which becomes cream-colored as the flower develops. Splendid size and texture. Fine stems.

Spring Glory. (Trumpet-Bicolor.) Clear white perianth with Iong petals of frne form; trumpet deep yellow. One of the best of the newer types for pot culture . . . . . . . . . .

Sunrise. (Barri.) White with primrose bar down the center of each petal; large, open crown of orange-yellow with scarlet margin

$150 \quad 1100 \$ 10000$

$200 \quad 1300 \quad 12000$

The Star. Poeticus (Poeticus.) Pure white perianth, with small, regular Poeticus eye. This is the Iatest flowering of all Daffodils . .

Thelma. (Leedsi.) Snow-white perianth with overlapping petals; cup yellow, edged crimson. Has a fascinating perfume.

Treserve. (Trumpet.) Large yellow trumpet; pale yellow perianth. One of the largest and handsomest varieties . . . .

Van Waveren's Giant. (Trumpet-Bicolor.) Next to Robert Sydenham, the Iargest of aII Bicolor Daffodils. Perianth primrose; bright yellow trumpet. Splendid forcer and vigorous grower . . . . . . . . . . . . . . . . . .

Victoria. (Trumpet-Bicolor.) Broad, creamy white perianth; Iarge yellow trumpet. Recommended for forcing.

Mother Bulbs. XXX . . . . . . . . . . . . .

First-size Bulbs. XX . . . . . . . . .

Weardale Perfection. (Trumpet-Bicolor.) Perianth white with broad petals; long rich yellow trumpet. A good grower and very free-flowering ........... . 400

Whistler. (Trumpet.) A magnificent variety. Produces Iarge handsome flowers with golden yellow trumpet and chromecolored perianth. This giant variety supersedes all others in this class .

\section{8}

White Lady. (Leedsi.) Cup pale canary-yellow; perianth white. Very fine . . . . . . . . . . . . . .

Whitewell. (Incomparabilis.) Petals pure creamy white; bold open crown of orange-yellow. Excellent size and texture . .

Will Scarlet. (Incomparabilis.) Creamy white perianth with large fiery orange-red cup. Flowers nod . . . . . . . . .

Yellow Poppy. (Incomparabilis.) Exquisite flower of perfect form. Perianth and small cup of delicate brimstone-yellow .

$\begin{array}{lllll}125 & 900 \quad 8000\end{array}$

$250 \quad 1500$

$250 \quad 1500$ 


\section{Hunt's PERFECTION Bulbs}

\section{Jonquils}

In this group the flowers are much smaller than many other varieties and the plants have a thin, rush-like foliage.

Doz. $\quad 100 \quad 1,000$

Campernelli, Orange Queen. This form is of that tint of yellow which, although not an orange, strongly suggests that shade

Campernelli rugulosus. Broad, rich yellow perianth and cup. . 125

$\begin{array}{llll}7 & 50 & \$ 70 & 00\end{array}$

Jonquilla. Single, sweet-scented, rich yellow Jonquil . . . 100

$700 \quad 6000$

Triandrus, Thalia. Produces three or four fine white flowers per stem. Very distinct and charming introduction. \$1.50 each . 1500

\section{Narcissus, Double Varieties}

This group comprises the double-flowering varieties.

Doz.

Albo-pleno odorata. Double pure white. Excellent for cutting \$1 75

$100 \quad 1,000$

$\$ 1200 \$ 11000$

Orange Phœnix (Bacon and Eggs). Large, double white flower with orange base . . . . . . . . . . . 200

Primrose Phœnix. Large, rose-shaped primrose-yellow flower on long stem . . . . . . . . . 200

Sulphur Phœnix (Codlins and Cream). Large, double white flower with sulphur center . . . . . . . . . . . . .

Von Sion. The popular old-fashioned double Daffodil. Rich golden yellow. Excellent for forcing or bedding.

Mother Bulbs. XXX . . . . . . . . . . . . . . . 200150014000

First-size Bulbs. XX . . . . . . . . . . . . . . . . . 175130012000

New Daffodil-Double Yellow Perfection. This is a double form of Emperor. Very fine flower of good substance and color. May be forced or grown outside with splendid results. When more plentiful will completely eclipse the well-known Von Sion

$200 \quad 1500 \quad 14000$

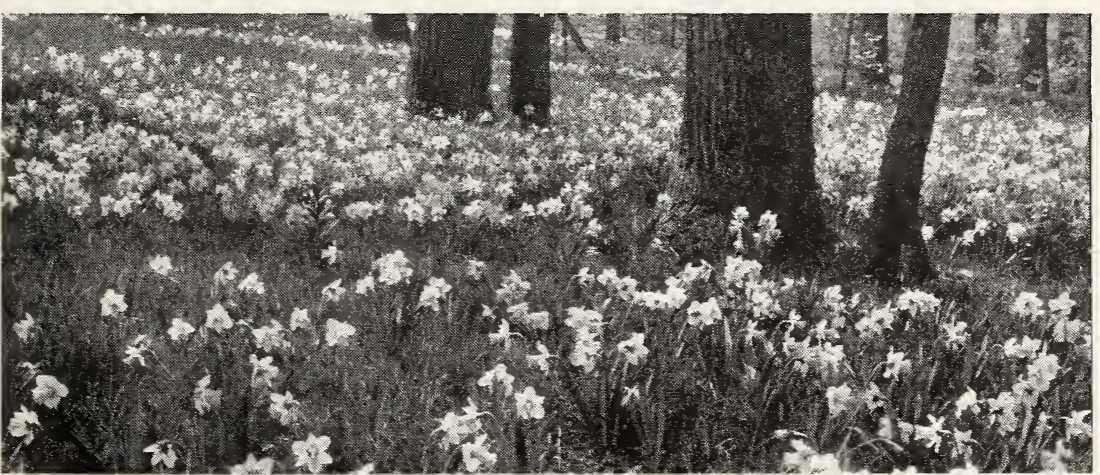

\section{Narcissus and Daffodils Mixed for Naturalizing}

This mixture contains many varieties of Narcissus and Daffodils that are most suitable for planting in borders, lawns, and woodlands, and comprise sorts which will give an abundance of flowers and continue to thrive indefinitely. $\$ 1.25$ per doz., $\$ 9$ per 100 , $\$ 85$ per 1,000 . 


\section{William M. Hunt $\underset{\text { incorporated }}{\&}$ Company}

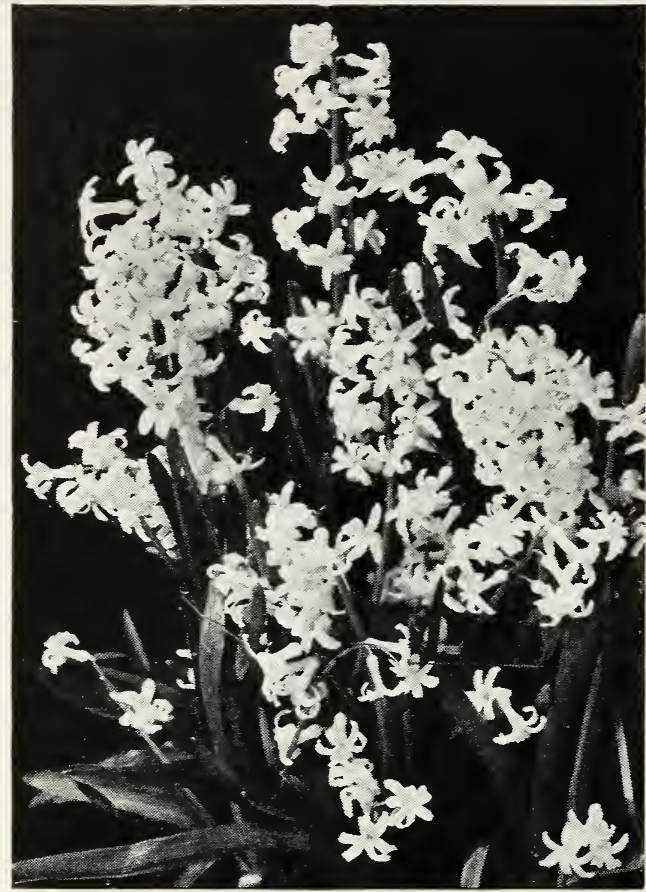

Roman Hyacinths

\section{Early Roman Hyacinths}

The early Roman Hyacinth, with its graceful spike of fragrant beIIs, is one of the earliest of aII winter-flowering bulbs.

New-crop bulbs will be ready in September, when they may be planted in pots or pans of a compost containing two-thirds fibrous loam and one-third sand. They may also be placed in the more artistic ornamental bowls now available in any china store, using our prepared Bulb Fibre as a filler, which only needs to be kept continually moist, requires no additional fertilizer, and in which the bulbs thrive and bloom Iuxuriantly. Bulbs planted in September bloom in December.

White. Extra

Doz. $\quad 100$

large. XXX.$\$ 300 \quad \$ 1800$

White. Selected

Bulbs. XX . . $250 \quad 1650$

\section{Prepared Dutch Hyacinths}

These bulbs are intended only for indoor planting and have, both in growing and harvesting, been submitted to a treatment that insures early ripening and leaves them in a condition to respond to intense forcing methods for early bloom. Planted in September, they bloom about the same time as the Roman Hyacinths, or soon after them.

Bismarck. Sky-blue

Doz. $\quad 100$

Garibaldi. Dark carmine . . . . . . . . . . . . . . 2001450

Gertrude. Deep rose . . . . . . . . . . . . . . . 2001450

Grand Monarque. Dark blue . . . . . . . . . . . . . 2001450

L'Innocence. Pure white . . . . . . . . . . . . 2001450

Schotel. Light blue . . . . . . . . . . . . . . . . 2001450

Victor Emmanuel. Deep rose. . . . . . . . . . . . . . . 2001450

Yellow Hammer. Canary-yellow . . . . . . . . . . . . . . . . . 2001450

Bulb Fibre. A natural peat frbre, full of nutritious properties for the growing of flower bulbs indoors. This compost acts as a moisture-retainer, which promotes the growth of roots on the bulbs, at the same time releasing its organic fertilizing elements in soluble form, developing and maintaining a steady and sturdy growth on the bulbs until the flowers have matured. Peck $\$ 1.75$, bushel $\$ 6.50$. 


\section{Hyacinths for Garden and Home}

Hyacinths may be put to several uses: They may be grown in beds and borders, forced in pots or pans, or grown in water, and are very easy of cultivation. They possess a wonderful perfume, and there are many shades ranging through Pure White, Pale Blue, Lavender, Mauve, Purple, Red, Pink, Blush-White, and Yellow. Suitable alike for the amateur and professional grower. $\quad$ Each $\quad$ Doz. 100

EXHIBITION TOP-SIZE BULBS. (For pots.) . . . . . $\$ 030 \quad \$ 250 \quad \$ 1600$ SECOND-SIZE BULBS. (For forcing or bedding.) . . . . . $\quad 201501200$ MINIATURE BULBS . . . . . . . . . . . . . 15125800

\section{Single Blue}

Bismarck. Sky-blue; very ! arge spike. Excellent for forcing.

Dr. Lieber. Lavender-blue, tinged violet; large, perfect spike.

Duke of Westminster. Large deep purplish blue bells with white center.

Grand Maitre. Deep lavender-blue; Iarge and compact truss. Old popular variety.

King of the Blues. Compact truss of dark blue bells. Late variety.

Lord Balfour. Lilac-rose, tinged violet-a very pretty combination.

Menelik. Purplish black; large, compact truss. Very distinct.

Queen of the Blues. Pale azure-blue; Iarge spike. BeautifuI.

Schotel. Light blue; long, perfect spike. Good forcer.

Sir William Mansfield. Bright purple; good truss.

\section{Single Yellow}

City of Haarlem. Pure yellow; large truss. Extra-fine exhibition variety.

Yellow Hammer. Rich yellow; beautiful truss.

\section{Single White}

Arentine Arendsen. Pure white. Extra early.

Grande Blanche. The best blush-white; perfect florets on Iong spike.

L'Innocence. Pure white. The best white for all purposes.

La Grandesse. Pure white; fine bells. Best exhibition white varietv.

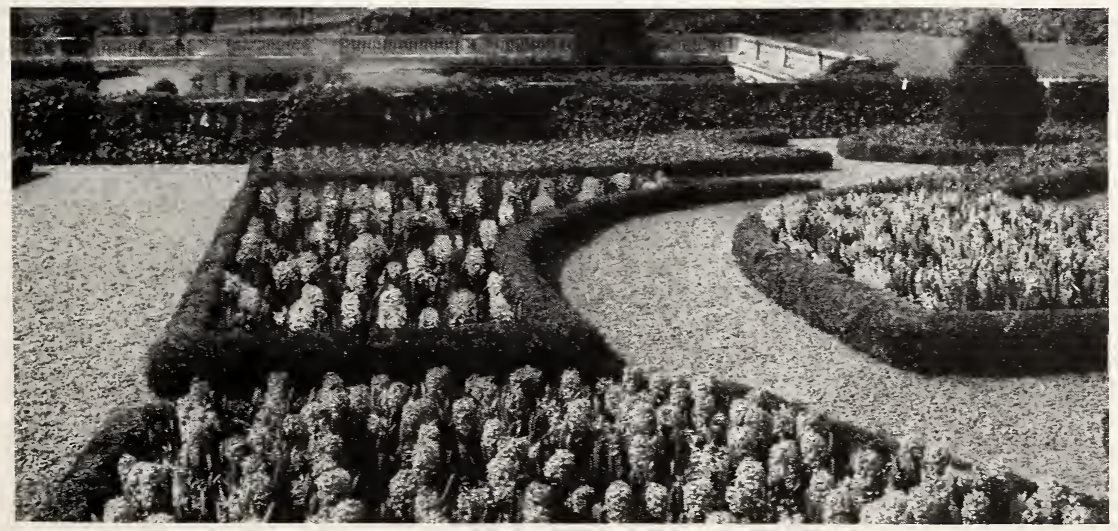




\section{William M. Hunt \& Company}

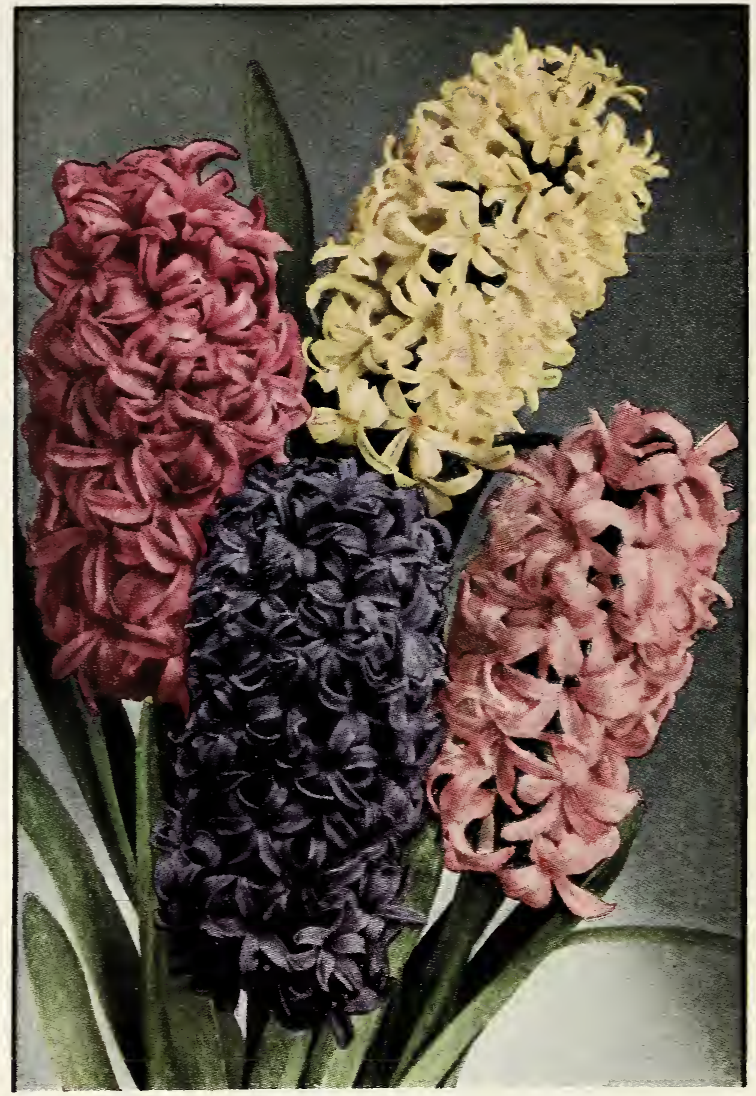

Marconi (Red) City of Haarlem (Yellow) Gertrude (Pink) King of the Blues

\section{Single Red and Rose}

Garibaldi. Glowing crimson-red. Very early.

Gertrude. Rosy pink; large, compact truss. OId and still popular.

Lady Derby. Rose-pink; large spike. Excellent for pots.

La Victoire. Deep carmine-rose; very fine spike. Splendid for exhibition.

Marconi. Bright rose; large, compact truss.

Queen of the Pinks. Rosy pink; extra-Iarge bells. Perhaps the best of this shade.

\section{Double Hyacinths}

Top-size bulbs

Bloksberg. Pale porcelain-blue.

Noble par Merite. Deep rose; splendid bells.

Princess Alice. Pure white. 


\section{Hunt's PERFECTION Bulbs}

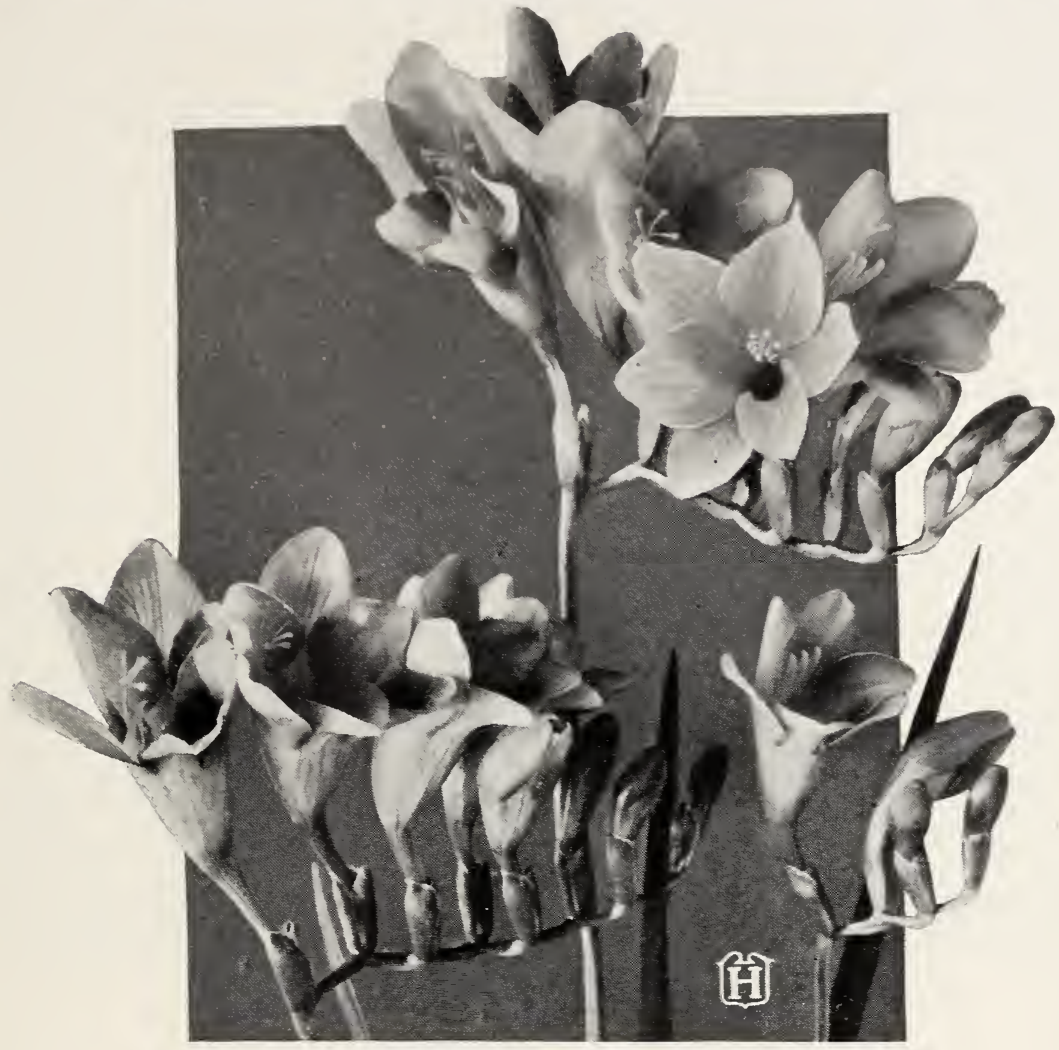

Golden Daffodil Freesias (See page 32)

\section{Freesias}

New-crop bulbs will be ready in JuIy, and if potted at once and kept in a coldframe until leaves are well developed and then brought in and not forced, they can be bloomed early for Christmas.

Elder's Giant White. Br far the largest white Freesia in existence;

$$
\text { Novelty Freesias } \quad 100 \quad 1,000
$$

almost twice the size of Purity. Top-size bulbs . . . . . . . . . $\$ 12 \quad 50 \quad \$ 11000$

Aurora. Yellow suffused orange . . . . . . . . . . . 7006000

Marie Fischer. (Fischer's.) Beautiful lavender-blue . . . . . . 10009000

Mrs. R. Craig. (Fischer's.) Uniform blue . . . . . . . . . . 110010000

Fink Beauty. (Frey's.) This is a distinct new type of Freesia-a

giant rose-pink with broad petals and flat, open flowers. It looks

more like an orchid spray than a Freesia. Top-size bulbs . . . . $1350 \quad 12500$

Sunset. Beautiful new flame-orange color. This variety was the greatest attraction in the field during flowering season. Top-size bulbs . . . . . . . . . . . . . . 140013000 


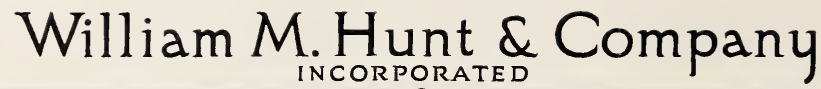

\section{FREESIAS, continued}

Purity. (Casad's.) Large, snowy white flowers, borne in great pro- 100 1,600 fusion on upright, stiff stems 2 to $2 \frac{1}{2}$ feet long. Largest Bulbs. XXX Second Size. XX .

Fischeri. Mammoth, pure white variety . . . . . . . . . . . . . 800

Golden Daffodil. The Iargest and best yellow Freesia. Large, deep yellow flowers borne on long, strong stems. Largest bulbs . . . .

$1200 \quad 11000$

Golden Treasure. Extremely Iarge and graceful flowers. The golden yellow petals are lightly tinged with lavender. Strong, Iong stems. Very attractive and distinct. Largest bulbs . . . . . .

California. Large bright golden yellow flower. Extra-fine. Strong growth and long stems

$1200 \quad 11000$

$650 \quad 6000$

Carmencita. Light orange-saImon hue, buff shading on the Iower petals

Carrie Budau. Large lavender-pink flowers and heavy stems . . . .

Gen. Pershing. Uniformly large flowers of an exquisite shade of rosepink

June Michelsen. Large; deep rose-pink, light blush throat; three Iower petals veined purplish crimson, with a yellow blotch on center petal . . . . . . . . . . . . . . . . . .

Mendota. One of the newer giant Freesias. Splendid clear yellow flowers on long, strong stems . . . . . . . . . . . . . . . . .

Mrs. Marc Peters. Very early giant pink. One of the most popular of recent introductions. Flowers are large, borne on long, stiff stems .

Viola (Amethyst). Delicate violet-blue. Handsome . . . . . . . .

Wistaria. This is, without doubt, the best blue Freesia disseminated to date. Flowers are of deep Wistaria-blue and are borne on strong, wiry stems. Importation permits will not allow delivery before October, but orders for a limited quantity may be booked now for delivery at that time

Yellow Prince. Large yellow flowers

Giant Colored Hybrids. A mixture of various shades of Iavender, orange, pink, yellow, etc.

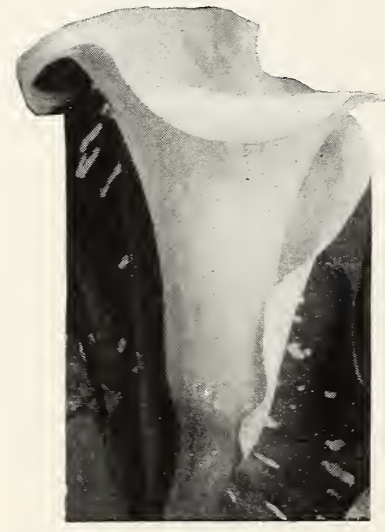

Calla Lily

\section{Calla Lilies (Richardia)}

Athiopica (White CaIla).

Doz. 100

Mammoth Bulbs. XXX . . . . . . . \$6 $00 \quad \$ 4500$

Selected Bulbs. XX

Godefroyana (SmaIl White Calla). Freeflowering ........... . . . 5504000

Elliottiana. Golden yellow.

Top size. XXX . . . . . . $750 \quad 5250$

Selected Bulbs. XX

Black Calla (Arum pictum). A very interesting novelty. Flowers are purplish

black. Leaves light green. Height $2 \mathrm{ft}$. $600 \quad 4500$

Be sure to plant some Lilium regale this autumn, illustrated and described on pages 36 and 37 


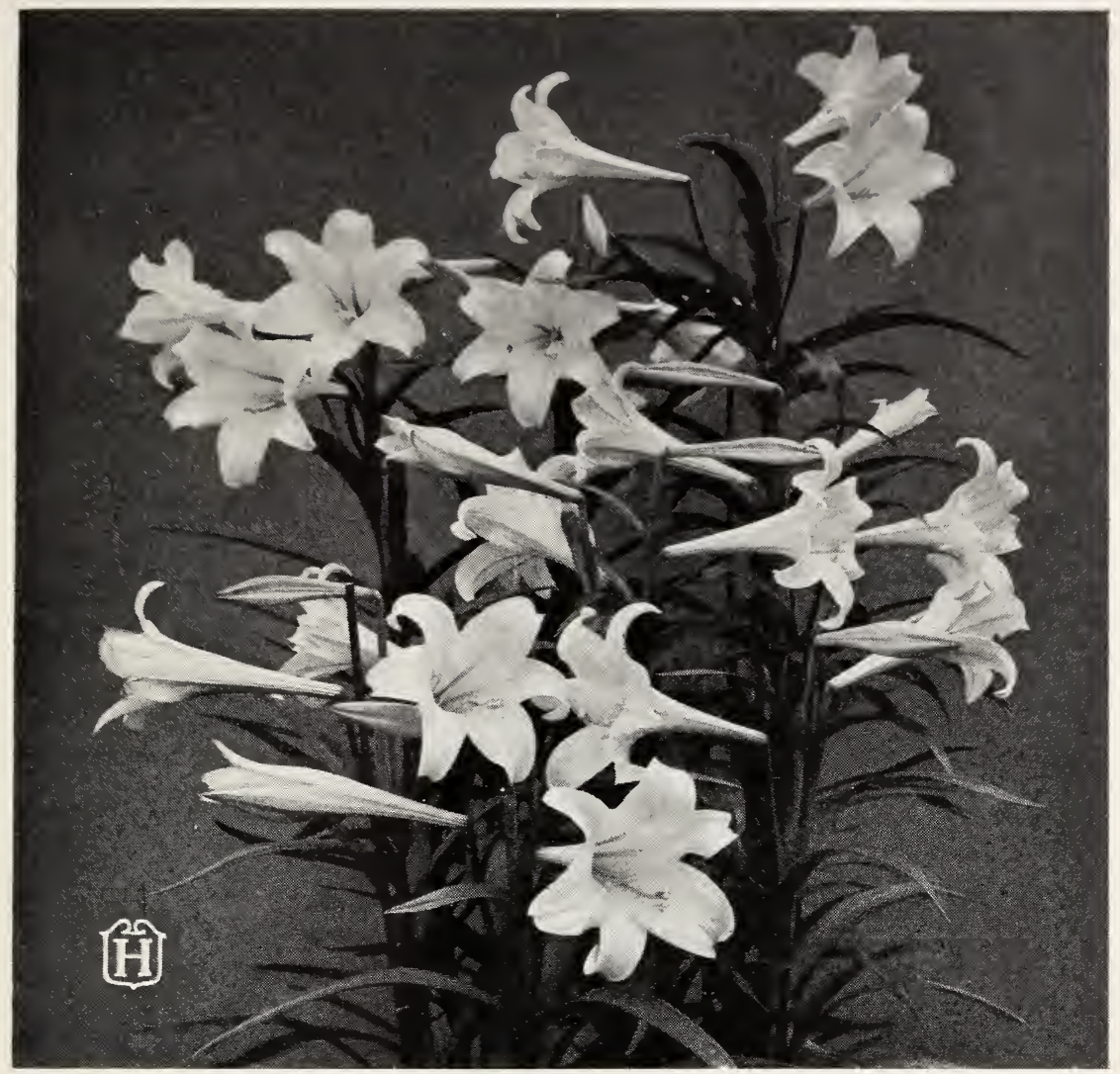

Lilium Harrisi

\section{Early-flowering and Forcing Lilies}

The finest varieties of Lilies, admirably adapted for spring forcing, and especially desirable to have in pots for Easter and earlier.

Candidum. Mammoth Bulbs. XXX

Doz. 100

Large Bulbs. XX

$\$ 650 \quad \$ 4500$

Harrisi. The true Bermuda Easter Lily.

Mammoth Bulbs. XXX. 11 to 13 in. cir. . . . . . . . . . . . 12009500

Large Bulbs. XX. 9 to 11 in. cir. . . . . . . . . . 10007000

Azoricum. Similar to $L$. Harrisi except that it is Ionger in the trumpet.

9 to 11 in. cir. . . . . . . . . . . . . . . . 10007000

Longiflorum formosum. Earliest of Easter Lilies. Free of disease and easy to force.

Top-size Bulbs. XXX. 11 to 13 in. cir. . . . . . . . . . . . . 10007000

First-size Bulbs. XX. 10 to 12 in. cir. . . . . . . . . . . . . . 8006000

Second-size Bulbs. X. 9 to 10 in. cir. . . . . . . . . . . . . 6004000

Longiflorum giganteum. Large flowers of excellent quality.

Top-size Bulbs. XXX. 10 to 12 in. cir. . . . . . . . . . . . . . 8006000

First-size Bulbs. XX. 9 to 10 in. cir. . . . . . . . . . . . 6504500

Longiflorum Erabu. Similar to Formosum but much taller.

Top-size Bulbs. XXX. 10 to 12 in. cir. . . . . . . . . . . . . 10007000

First-size Bulbs. XX. 9 to 10 in. cir. . . . . . . . . . 7005500 


\section{William M. Hunt \& Company}

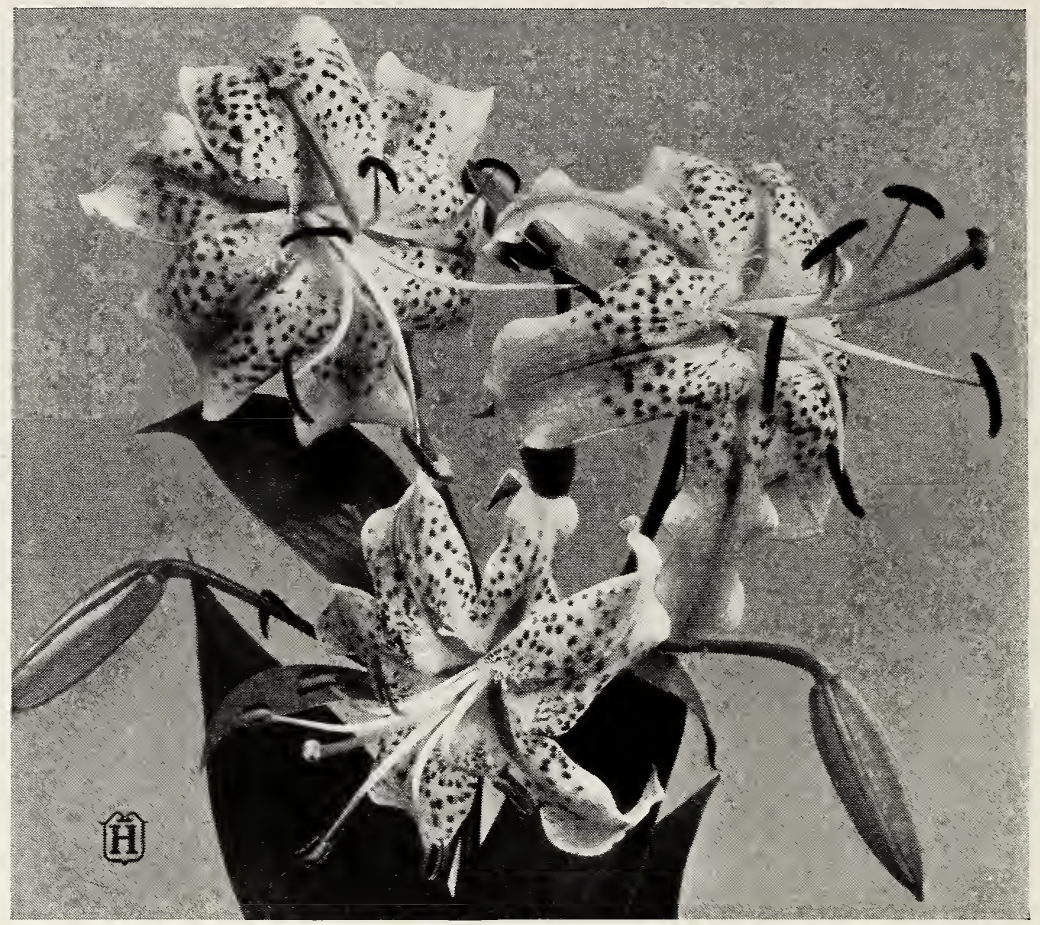

Lilium speciosum rubrum

\section{Cold-Storage Lilies}

We carry in cold storage a Iarge stock of the following Lilies for shipment at any season of the year.

Batemanniæ. Apricot . . . . . . . . . . . . . . . $\$ 400 \quad \$ 3000$

Croceum. Orange-red . . . . . . . . . . . . . . 8005500

Giganteum. White. 10 to 11 in. cir. . . . . . . . . . . . . 9006500

Henryi. Soft yellow. 8 to 9 in. cir. . . . . . . . . . . . . . . 9006000

9 to 10 in. cir. . . . . . . . . . . . . . . . . . . . 10007000

Regale. White trumpet, with yellow throat. 8 to 9 in. cir. . . . . . . 10007500

Speciosum album. White. 9 to 10 in. cir. . . . . . . . . . . . . 9006500

Speciosum magnificum. Deep rose. 11 to $13 \mathrm{in.} \mathrm{cir.} \mathrm{.} \mathrm{.} \mathrm{.} \mathrm{.} \mathrm{.} \mathrm{.} \mathrm{.} \mathrm{.} 9006500$

Speciosum melpomene. Crimson-pink. 11 to 13 in. cir. . . . . . . . 9006500

9 to 11 in. cir. . . . . . . . . . . . . . . . . 7004500

Speciosum rubrum. Rose-pink. 11 to 13 in. cir. . . . . . . . . . 9006500

9 to 11 in. cir. . . . . . . . . . . . . . 7004500

Tigrinum, Single. Orange-red . . . . . . . . . . . . . 3502500

Tigrinum, Double. Orange-red . . . . . . . . . . . . . 4003000 

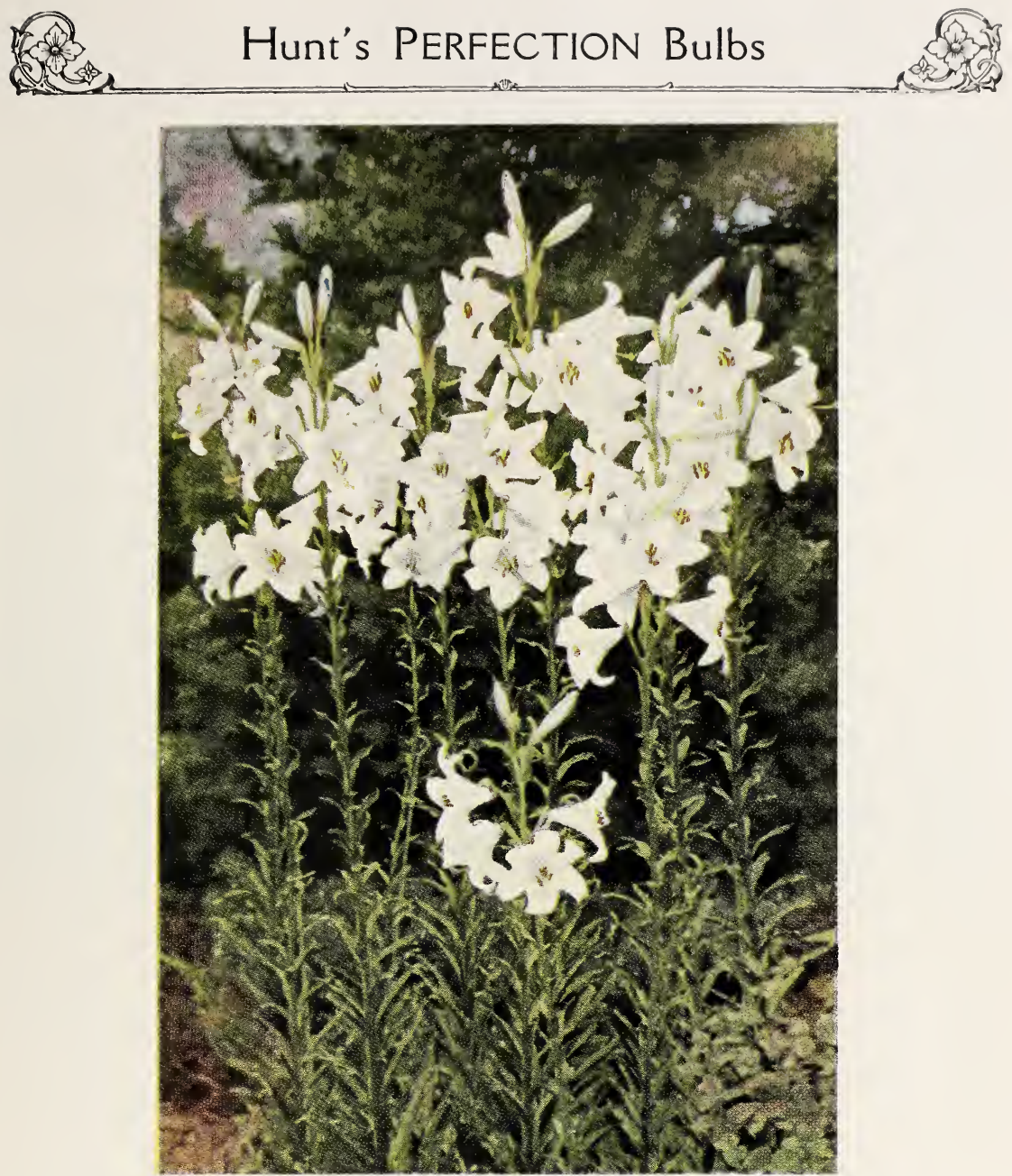

Lilium candidum. See page 36

\section{Hardy Garden Lilies for Fall and Spring Planting}

Hardy Lilies are among the most gorgeous subjects for the garden that can be planted. When happily placed they throw up sturdy stems in an eager desire to unfold their wonderful flowers above the heads of their companions, holding the admiring gaze of all who pass.

AII Lilies do not like the same conditions. The one universal requirement for all is absolutely perfect drainage. The loose, scaly bulbs which Lilies produce are susceptible to rot in wet soil, and it will pay to go to some pains to be sure that the ground for them is properly drained. When Lilies are well established in the garden, it is well to feed them with a top-dressing of manure after the tops have died down in the autumn. It is better to omit manure from the preparation of the Lily-bed before planting.

Some Lilies make two sets of roots, one set below the buIb which nourishes and stores up the food for next year's flowers, and another set above the bulb which supplies moisture and soil-elements for this year's flowers. The bulbs of such Lilies in their natural homes are usually found very deep in the soil. In planting in the autumn, it 


\section{William M. Hunt \& Company}

\section{LILIES, continued}

is wise to set such Lilies 6 to 8 inches deep. However, since the roots of Lilies have strong, contractile power, they will seek their own level eventually, so that errors in the depth of planting will be corrected by the Lilies themselves.

Another group of Lilies makes no stem-roots at all. These bulbs should not be put down more than twice the depth of the bulb itself.

AImost all Lilies need a mulch, either of leaves or some living plant, to protect the base of the stems from the summer sun. A few of them do very well when interplanted with low shrubs, such as rhododendrons and azaleas. Almost all of them will benefit by giving the tops plenty of sky-room, so that the flowers can have sunlight.

The most beautiful Lilies are Lilium auratum, L. regale, L. speciosum, varieties Melpomene and Album, L. tigrinum, and L. Henryi.

Auratum (The Golden-banded Lily of Japan). One of the stateliest of all the hardy Lilies; grows 3 to 6 feet high and bears tw enty or more large and fragrant flowers 8 to 10 inches in diameter. Planted in clumps of six or so, they make an attractive sight. Flowers white, spotted deep red, with bright yellow band running through the center of each petal, in August.

Mammoth Bulbs

Doz.

$\$ 750$

100

Extra-large Bulbs

600

$\$ 5500$

Large Bulbs.

$350 \quad 2750$

Candidum (Madonna or Annunciation Lily). The bulbs we offer are the true, hardy, Northern French-grown; arriving here in September, they should be planted at once, in groups of from 3 to 6 dotted among the taller-growing perennial plants in the herbaceous border. They make their leaf-growth in October, then die down and bloom Iate the following June-stately spikes of Iarge, white, fragrant flowers with yellow anthers. The new Hybrid Delphiniums (Wrexham Strain), Campanula Pyramidalis, and tall-growing pink Gladiolus, planted in proximity make a border of exquisite charm in June and July.

Doz. $\quad 100$

Specially selected top-size Bulbs. XXX . . . . . . . . . . \$6 $50 \$ 4500$

Mammoth Bulbs. XX . . . . . . . . . . . . . . . 4503500

Batemanniæ. Beautiful Japanese variety, growing 3 feet high, with six to eight apricot-colored flowers held erect on a stem. Blooms in July and August . . . . . . . . . . . . . . . . . . . . . . :

Canadense (Meadow Lily). A stout-stemmed Lily with whorled leaves, bearing a spreading, loose panicle of drooping, bell-shaped flowers, usually orange or scarlet spotted with brown and maroon. This Lily seeks low, moist ground and needs a mulch of leaves or plants about its roots, with the tops open to the sun. 2 to 5 feet high. Flowers in June and July . . . . . . . . . . . . . . . . . . . . . . . .

Croceum. A strong-stemmed Lily bearing erect flowers in a pyramidal cluster in June and July. The blooms are yellow and orange, spotted red, and very freely produced. 3 to $4 \mathrm{ft}$. . . . . . . . . . . . . .

Henryi (Yellow Speciosum). 4 to $5 \mathrm{ft}$. In form and habit resembles $L$. speciosum. Flowers shaded yellow, slightly varying in color, with a distinct and waxy green center. Blooms during August and September.

Regale. 3 to $4 \mathrm{ft}$. The finest and most easily grown is the Lily producing large, flared trumpets suffused with gold and yellow on the inside and slightly stained with purple on the backs of the outer petals. The stem is stout and very wiry, so that the plant takes up very little room after flowering. It blooms immediately after the Madonna Lily and is one of the finest plants to be found in gardens.

Mammoth Bulbs. XXX . . . . . . . . . . . . . . . 1000

Large Bulbs . . . . . . . . . . . . 900

9000

7500

Speciosum Album. 3 to $4 \mathrm{ft}$. This is a very dainty white Lily. It flowers in the border or amongst the shrubbery at the same time as L. auratum, and is one of the most popular varieties. Used extensively in pots for greenhouses.

Extra-large Bulbs . . . . . . . . . . . . 1000

Large Bulbs . 


\section{Hunt's Perfection Bulbs}

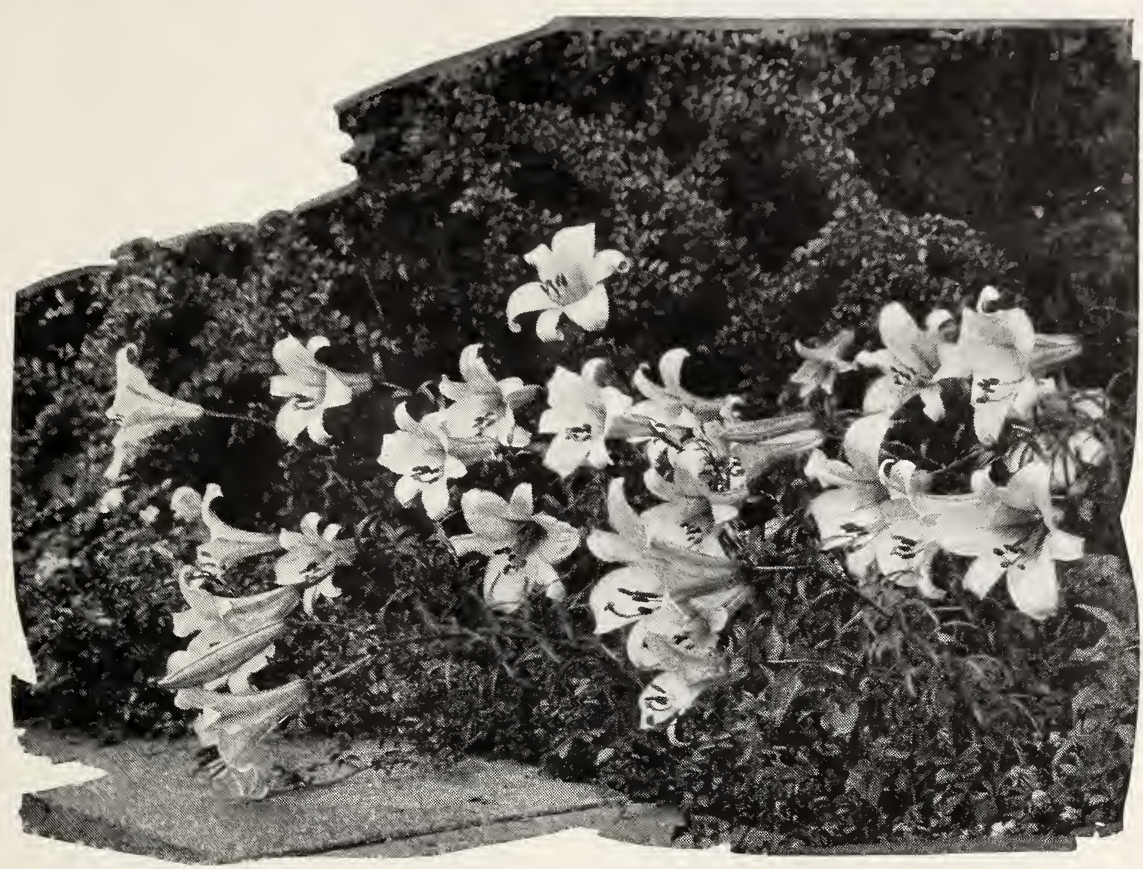

Lilium regale

\section{LILIES, continued}

Speciosum Melpomene. Large, dark crimson spotted flower of striking Doz. appearance. Profuse flowering.

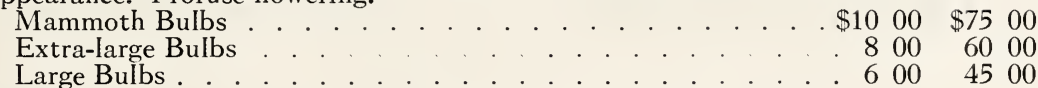

Speciosum Rubrum. 3 to $4 \mathrm{ft}$. Bears an abundance of spotted rose flowers. Blooms outdoors August and September.

Mammoth Bulbs . . . . . . . . . . . . . . . . . 10007500

Extra-large Bulbs . . . . . . . . . . . . . . . . . . . . 8006000

Large Bulbs . . . . . . . . . . . . . . . . . . . . . . . . . . . . 6004500

Tigrinum Splendens (Tiger Lily), 3 to $4 \mathrm{ft}$. The popular, old-fashioned

Tiger Lily is well known by its brilliant orange flowers spotted with maroon and black. It enjoys full sun with a ground-cover. Very

hardy. Blooms in August . . . . . . . . . . . . . . . . . 350

2500

Tigrinum flore-pleno (Double-flowering Tiger Lily). Like above but

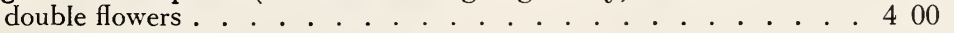

\section{Lily-of-the-Valley}

Extra-strong Berlin pips, for forcing, from cold storage. $\$ 9$ per case of 100, $\$ 18$ per case of 250, $\$ 70$ per 1,000.

Berlin Pips, Fresh Pips, ready in December, \$16 per case of 250.

Extra-strong clumps (November delivery). 60c. each, $\$ 6.50$ per doz., \$50 per 100 . 


\section{MISCELLANEOUS BULBS}

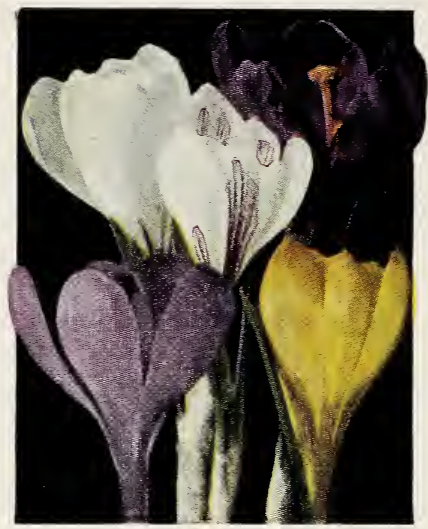

Crocuses. See opposite page

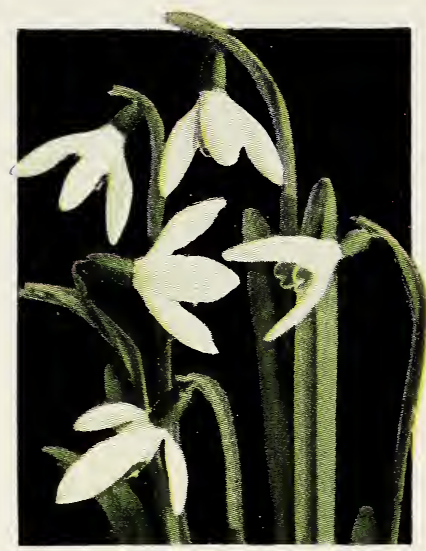

Galanthus (Snowdrops) See page 43

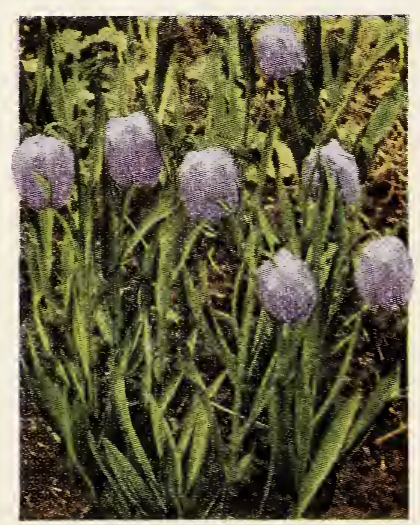

Fritillaria meleagris See page 41

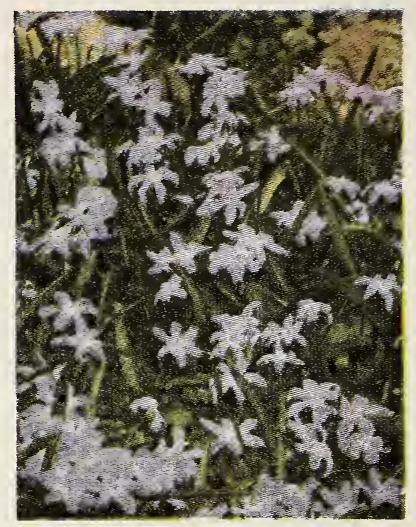

Chionodoxa Luciliæe See page 40

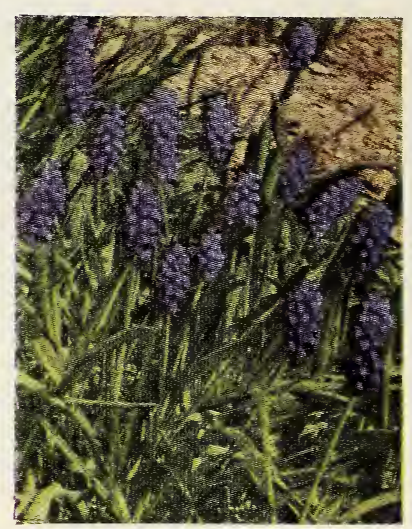

Giant Grape Hyacinths See page 43

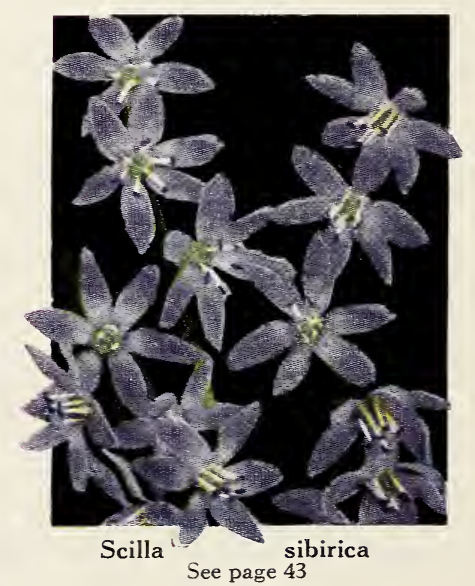




\section{Hunt's PERFECTION Bulbs}

\section{Spring-flowering Crocus}

The harbinger of spring and the good things which follow. Whether planted in beds, borders, or scattered through the lawn, they are very attractive.

Top-size bulbs only

\section{Blue Shades}

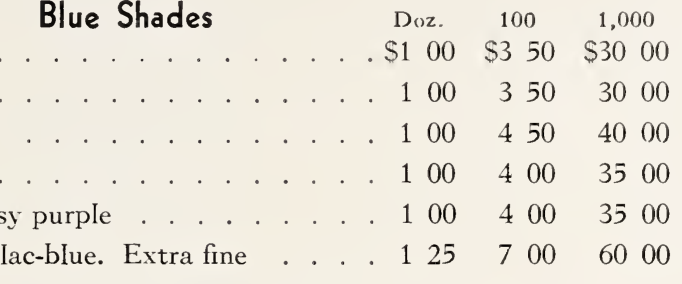

Albion. Dark purple

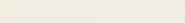

Baron von Brunow. Dark blue

.

Caesar. Very Iarge purple flower.

Non Plus Ultra. Clear blue

\section{White Varieties}

King of Whites. Largest white

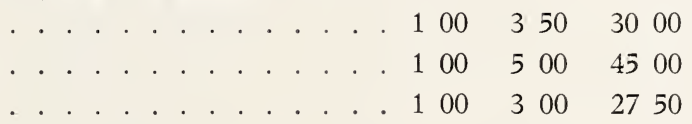

Kathleen Parlow. Purest white

\section{Striped Varieties}

Pallas. White ground striped Iilac. Extra-large flower . . . . 10033503000

Princess Louise. Deep purple, light stripes . . . . . . . . . 1003503000

Sir Walter Scott. Violet and white . . . . . . . . . . $100300 \quad 2750$

Cloth of Gold. Very early

\section{Golden Yellow Varieties}

Mammoth Golden. Jumbo bulbs . . . . . . . . . . . . . 1004003750

\section{Mixed Crocus}

Extra-large bulbs mixed, from above named varieties

\section{Miscellaneous Bulbs for Spring Flowering Amaryllis}

For growing in the house or conservatory, few plants produce as striking a display, with so little trouble, as Amaryllis. The bulbs should be potted in the fall, be kept rather dry all winter until growth starts in early spring when they should be watered plentifully, fertilized and lightly shaded. A few weeks, and they break into immense lily-like blooms of gorgeous color and form.

Vittata Hybrids. 'This selection contains a mixture of the finest unnamed Each Doz. seedlings in cultivation. The colorings and markings are unique and provide a show of unexampled beauty. Extra-large, sound bulbs of

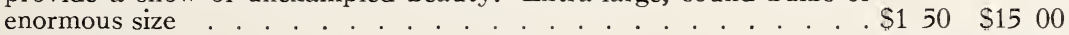

White Shades . . . . . . . . . . . . . 1751750

Deep Pink Shades . . . . . . . . . . . . . . . . . . 1751750

Solid Red Shades . . . . . . . . . . . . . . 1751750 


\section{William M. Hunt \& Company}

\section{Anemone}

Gorgeous, whirled flowers of brilliant colors-scarlet, blue, pink, white, etc.--with strongly contrasted centers. They are splendid cut-flowers and make a frne showy bed. In most sections the bulbs need about the same protection afforded pansies. They can be kept in a frame over winter and be moved into the garden when in bud or bloom.

French, Single Mixed

Doz. $\quad 100 \quad 1,000$

St. Brigid, Mixed, Irish Strain _. . . . . . . . . . . 15095509000

\section{Chionodoxa}

Lovely blue and lavender flowers much like scillas, except that the flowers are held $\begin{array}{llll}\text { erect, and are useful for the same purposes. } & \text { Doz. } & 100 & 1,000\end{array}$ Luciliæ (Glory-of-the-Snow). Blue with white center . . . . . \$0 $50 \quad \$ 2 \quad 50 \quad \$ 2000$ Sardensis. Intense bright bue . . . . . . . . . . . . . 502752400

\section{Colchicum (Autumn Crocus)}

Autumnale major. Planted in September, they produce handsome Doz.

flowers like large rosy lavender crocuses within a few weeks. The

foliage comes in spring and dies down in summer. They are perma-

nent and increase. Lovely for autumn color . . . . . . . . . . . \$4 $00 \$ 3000$

\section{Cypripediums (Native Orchids or Ladyslippers)}

These hardy plants require acid soil and partial shade. The delicately beautiful blooms have a large, pouched petal or "lip," forming the "slipper," with curiously curled standards or waved perianth of petals and sepals behind it, usually of contrasting colors.

Acaule. Broad Ieaves, with a single stem between them, bearing a Iarge Doz.

100

pink flower. Strong acid soil, a somewhat dry situation, and plenty of shade. One of the loveliest. It may be forced gently in pots with great success

Pubescens (Yellow Ladyslipper). Erect, leafy stems bearing several yellow-pouched flowers of great charm, daintily spotted with brown. Acid soil, moist ground, and shade . . . . . . . . . . . . . . .

Spectabile (The Queen's Orchid). Similar to Pubescens in habit, with larger flowers. Pouch rose-red or white, stained rose. Peaty, sour soil, plenty of moisture and shade. A swamp plant in the wild. The handsomest native Orchid. 3 to 4 crowns

\section{Dielytra (Dicentra)}

Spectabilis (Bleeding-Heart). Not a bulb, but strong roots which produce lovely foliage and long racemes of pink, heart-shaped flowers in May. Especially valuable for shady places and for forcing . . . . .

\section{Eremurus}

Extremely rare plants of liliaceous habit, throwing up Iofty stems bearing tremendous spikes of lily-like flowers. The fleshy, spider-like roots should be planted in a sheltered place because the new growth is susceptible to damage by late spring frost, and ought to be left undisturbed as they improve with age.

Each Doz.

Bungei. Deep yellow flowers . . . . . . . . . . . . . . . $\$ 300 \$ 3000$

Elwesi. Soft pink . . . . . . . . . . . . . . . . 4004500

Himalaicus. White flowers with golden anthers . . . . . . . . . . 3003000

Robustus. Rosy pink . . . . . . . . . . . . . . . . . 4004500

Warei. Salmon-buff with shadings of yellow, pink, and orange . . . 1000 


\section{Hunt's PERFECTION Bulbs}

\section{Fritillaria}

Closely related to lilies; should be left undisturbed for years.

Doz. $\quad 100$

Imperialis aurora (Crown ImperiaI). Orange flowers . . . . . . . . \$4 $50 \quad \$ 3000$

Meleagris alba (Checkered Fritillaria). White . . . . . . . . 100600

\section{Gladiolus}

$\begin{array}{llll}\text { Early varieties which force readily, selected for indoors. } & \text { Doz. } & 100 & 1,000\end{array}$

Ackermani. Orange-scarlet with darker blotch . . . . . . .\$1 $25 \quad \$ 800 \quad \$ 7000$

Christmas Glory. This is a large-flowering type which if planted

in September in the greenhouse will produce large spikes of

crimson flowers for Christmas . . . . . . . . . . . $150 \quad 1000 \quad 9000$

Colvillei, The Bride. Pure white. Excellent for forcing . . . . 1007507000

Blushing Bride. White, flaked pink . . . . . . . . . . 1007507000

Peach Blossom. Rosy blush-pink . . . . . . . . . . . 1007507000

Tristis. Extra-fine yellow; very good forcer . . . . . . 3002000

\section{Prepared Gladiolus for Early Forcing \\ Delivery October 1}

Excellent results have been obtained from the following varieties for indoor forcing. They flower at Christmas and early in the spring. These bulbs are grown in the Southern States, cured in July, and are ready for planting about the end of September. Our list is somewhat limited, but we give a selection that is in great demand.

100

Alice Tiplady. (Primulinus.) Brilliant orange-salmon . . . . . . . . . . . $\$ 800$

Los Angeles. Pale pink with orange-salmon blotch in throat . . . . . . . . 1500

Mary Pickford. Delicate creamy white, throat soft yellow . . . . . . . . 800

Mrs. Frank Pendleton. SaImon-pink with rich deep maroon blotch . . . . . 700

Souvenir. (Primulinus.) Pure yellow . . ... . . . . . . . . . . 800

Virginia. One of the best early scarlet varieties . . . . . . . . . . . . . 900

\section{Gloriosa}

Roehrsiana (Climbing Lily). A superb, lily-like climber, with slender Each Doz. stem, 6 to 10 feet high, bearing a profusion of orange-red flowers, like delicate tiger lilies. Beautiful in conservatory or greenhouse. Dormant

tubers in October . . . . . . . . . . . . . $\$ 125 \quad \$ 1250$

\section{Helleborus}

Niger (Christmas Rose). Hardy perennial plants which bloom in the middle of winter. White flowers flushed purple . . . . . . . . 1751800

\section{Ixias}

Finest Mixed. Handsome bulbous flowers for gentle forcing in Doz. $\begin{array}{rr}100 & 1,000\end{array}$ greenhouse and conservatory, blooming in early spring. Wide range of colors 


\section{William $M$ IN Hunt $\&$ Company}

\section{Iris (Fleur-de-lis) Add Character to Modern Gardens}

\section{Dutch or Holland Iris}

Iris Tingitana and Spanish Iris may be grown both in and outdoors. If planted indoors they should not be forced as they will be apt to come blind; given a slow treatment they will bloom without difficulty in the early spring.

Imperator. Early-flowering. Brilliant blue, large and well-shaped flowers on Iong, strong stems. The best for greenhouse culture. $\$ 10$ per $100, \$ 95$ per 1,000 .

David Bless. A very early blue variety. $\$ 2.50$ per doz., \$15 per 100.

Wedgwood. Was awarded First Prize at last year's International Flower Show, New York. Very early, large blue flower borne on long, strong stems. Splendid for greenhouse, flowering in March. \$4 per doz., \$22.50 per 100.

Albert Cuyp. White with yellow blotch.

Anton Mauve. Soft lilac-blue.

Frans Hals. Creamy yellow, shaded light blue.

Hart Nibbrig. Bright, clear blue.
Hobbema. Pure white with yellow falls, shaded light blue.

Rembrandt. Early. Deep blue, orange dots.

Yellow Queen. Fine-shaped flower of uniform golden yellow.

Any of the above varieties, $\$ 1.50$ per doz., $\$ 8$ per 100 , except as noted

\section{Spanish Iris}

Cajanus. Very fine canary-yellow, with King of the Whites. Purest white, with orange blotches on the falls.

King of the Blues. Deep blue; large-flowered.

King of the Yellows. Bright yellow. orange blotches on the falls.

Prince Henry. Beautiful shade of bronze.

Queen Emma. Deep yellow. One of the largest varieties.

\section{All named varieties, $\$ 1.50$ per doz., $\$ 7.50$ per $100, \$ 70$ per 1,000}

SPANISH IRIS, MIXED. A fine mixture of the above varieties; suitable for bedding and cutting. 90 cts. per doz., $\$ 6.50$ per $100, \$ 60$ per 1,000 .

\section{Iris Germanica (Bearded lris)}

Popular garden perennials for showy landscape effects. We list a selected few of reasonable price and charming colors. S. means standards, or erect petals; F., falls, or the drooping petals.

Doz. $\quad 100$

Cottage Maid. S. gray-blue; F. white . . . . . . . . . . . . . . \$2 $50 \$ \$ 1400$

Hector. S. yellow, tinged red; F. dark crimson . . . . . . . . . . . 2501400

Khedive. S. Iavender; F. white, tipped lavender and veined with brown. $250 \quad 1400$

Loreley. S. light yellow; F. violet, edged pale yellow . . . . . . . . 2501400

Perle. S. light lavender; F. a darker shade . . . . . . . . . . . . 2501400

Rhein Nixe. S. pure white; F. rich blue edged white . . . . . . . . 2501400

\section{Iris Kaempferi (Japan Iris)}

Magnificent garden plants, blooming Iater than the Bearded Iris, producing handsome, flat flowers of great size in enchanting color-combinations. Doz.

Gold Bound. Very large, pure white petals with rich yellow center . . . . . . \$700

Mahogany. Dark mahogany-red. Very rich and sumptuous . . . . . . . . . 700

Oriole. Double flowers of rich red-violet with a velvety purple sheen . . . . . 700

Templeton. Double flowers of light blue with rosy white markings . . . . . . 750

Toledo. Single white flowers stained rose . . . . . . . . . . . . 800

Victor. White, shaded purple, with violet-blue veins . . . . . . . . 700 


\section{Hunt's PERFECTION Bulbs}

\section{Leucojum}

Vernum (Spring Snowflake). Similar to the Snowdrop but Iarger and later. \$1 per doz., $\$ 7.50$ per $100, \$ 70$ per 1,000 .

\section{Muscari}

Botryoides (Grape Hyacinth). Bluc. 50c. per doz., $\$ 1.75$ per $100, \$ 15$ per 1,000 .

Alba. White. \$1 per doz., \$5 per 100 , $\$ 40$ per 1,000 .

Heavenly Blue. Large light blue trusscs. 50 cts. per doz, $\$ 2.50$ per 100 , $\$ 20$ per 1,000 .

\section{Nerine (Amaryllidaceae)}

Splendid for greenhouse or frames. The bulbs produce large umbels of beautifully colored flowers that keep perfect and fresh for many days when cut.

Corusca major. Scarlet. \$22 per do?.

Fothergilli major. Scarlet. $\$ 22$ per doz.

Superb Hybrids. From one of the finest collections in cultivation. Many beautiful distinct shades. $\$ 15$ per doz.

\section{Oxalis}

Grand Duchess Mixed. Dwarf. Lavender, pink, white and yellow flowers. 60 cts. per doz., \$3 per 100, \$25 per 1,000.

\section{Ranunculus}

Much like anemones, and require same treatment. Gorgeous flowers in brilliant colors.

French Varieties, Mixed. For bedding or potting. \$1 per doz., \$6 per 100, \$55 per 1,000 .

FLORENTINE, Giant Mixed. This is a mixture of the largest and most brilliant-colored flowers. Recommended only for forcing. Strong 2-vear-old roots. $\$ 3$ per doz., \$17.50 per 100 .

\section{Scilla}

Splendid for naturalizing.

Sibirica (Blue Squill). 75 cts. per doz., $\$ 4$ per $100 \$ 35$ per 1,000 .

Campanulata, Blue(Blue Bells). 75 cts. per doz., $\$ 3$ per $100, \$ 25$ per 1,000 .

Campanulata Alba. White. 75 cts. per doz., $\$ 3$ per 100 , $\$ 25$ per 1,000 .

Campanulata Rosea. Fine shade of rose. $\$ 1$ per doz., $\$ 5$ per $100, \$ 45$ per 1,000 .

Nutans. The Blue BeIls of Scotland. 60 cts. per doz., $\$ 3$ per $100, \$ 25$ per 1,000 .

\section{SCILLA, continued}

SPRING GLORY. A ncw blue varicty of giant size, suitable either for growing in pots or masses in the border. \$2 per doz., $\$ 12$ per 100 .

\section{Snowdrops}

Splendid for naturalizing.

Single. Top-size bulbs. 60 cts. per doz., $\$ 3.50$ per $100, \$ 32$ per 1,000 .

Double. Top-size bulbs. 75 cts. per doz., $\$ 5$ per $100, \$ 45$ per 1,000 .

\section{Trillium}

Grandiflorum (White Lily). A superb native plant with an erect stem a foot or more high, crowned by three broad leaves in the center of which is a glorious, 3-petaled, Iily-like flower. Woodland conditions, shade, and leaf-mold are essential to true success. \$2 per doz., $\$ 10$ per 100 .

\section{Tritonia}

Crocata. Gorgeous tiger-like orange-scarlet flowers. Splendid pot-plants. \$1 per doz., \$7 per 100.

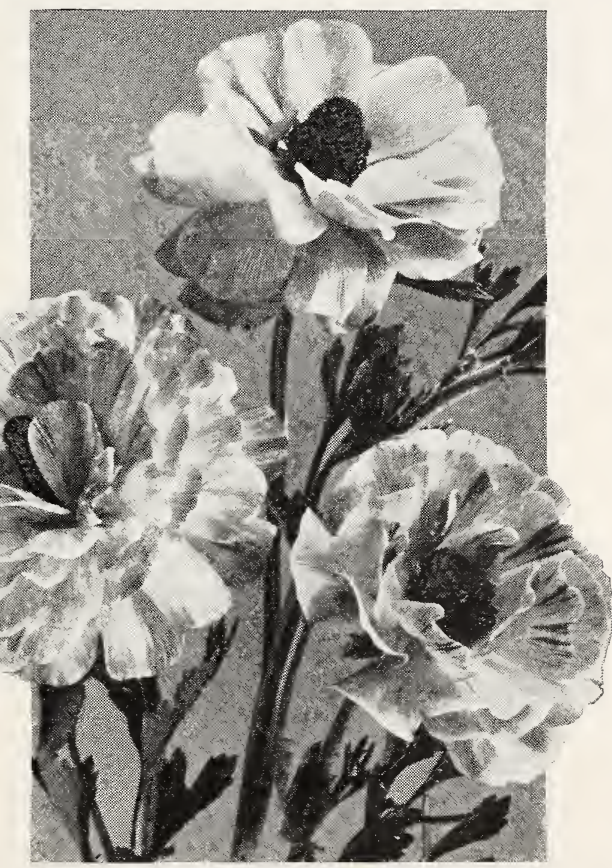

Florentine Ranunculus 


\section{William M. Hunt \& Company}

\section{Spiraea (Astilbe) Extra-arge Clumps}

We recommend the following varieties for forcing or outdoor culture. The clumps we offer are very large and cannot fail to give satisfaction.

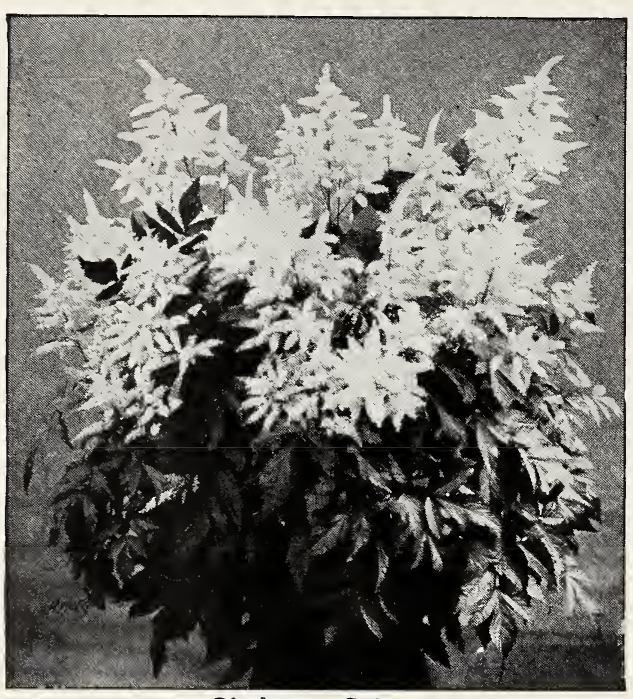

Gladstone Spiræa

Culture.-They require a compost of equal parts of Ioam and leafmold and should be potted singly in 6 or 7 -inch pots, in October or November. Place in coldframe until required for forcing; water freely when growth begins. Remove to coldframe after flowering and plant out in sunny position in June.

America. Lilac-rose-a beautiful orchid color with Iarge, feathery flower-spikes and beautiful foliage. This variety is one of the very finest and holds its color well. Medium height. (13 weeks.) \$8 per doz.

Ceres. Delicate Iavender-pink. Magnificent plumes, frequently measuring over $11 / 2$ feet, and altogether one of the showiest of aII Spiræas. The foliage is light green; plant very graceful and tall. (13 weeks.) $\$ 14$ per doz.

Cassandra. Dense, very double flowers of rosy red-the deepest color yet developed. Graceful foliage. (15 weeks). \$14 per doz.

Gladstone. Well-known and best white variety. Flower-spikes are cream-white, Doz. large, full, and feathery. Foliage is compact and deep green. Earlier than the pink kinds. We have a fine stock. (10 weeks)

Gloria Superba. This new variety has attained great popularity because of its brilliant dark pink color. Produces huge panicles of stately blooms borne on long stems. We have a very fine stock of this variety. (12 weeks) . . . 1200

Juno. Deep lilac-rose. GracefuI, spreading foliage. Slender flower-spikes of good shape. TaII grower and latest of all. (14 weeks) . . . . . . . . . . 1000

Kriemhilde. A pleasing and peculiar shade of soft creamy salmon with red flowerstems. Heavy, well-shaped plumes and graceful foliage. Medium height. (14 weeks)

Mont Blanc. Clear milk-white flowers. Deep green foliage; of dwarf habit. Free flowering. (14 weeks).

Peach Blossom. True peach-blossom color with red stamens. FuIl light green foliage. Holds color well. Very fine. (13 weeks) . . . . . . . . . . . . .

Philadelphia. Deep Iavender-rose. TaII and sturdy grower with abundance of gracefuI foliage. Heads are fuIl and feathery and the whole plant is Iarge. (14 weeks)

Princess Mary. Deepest rose-pink in commerce today. Flowers have slight lilac cast. Vigorous grower and in every respect a beautiful variety. Medium height. (14 weeks)

Queen Alexandra Improved. Soft light pink, large, individual recurved flowers, borne on heavy plumes. TaII and midseason. Foliage is abundant and of spreading habit with red stems and veins. (12 weeks). . . . . . . . . . 1000

Rubens. Attractive deep rose, with red flower-stems. Flat-growing foliage of glossy dark green. Medium height. (13 weeks) . . . . . . . . . . . 1000 


\section{Hunt's PERFECTION Bulbs}

\section{Watsonia}

Like graceful, loosely flowered gladiolus. Very popular for indoor culture.

America. Delicate pink.

Cream Cup. Creamy white.

Estrella. White.

Eunice. Salmon-pink.

Ed. Sturtevant. Brilliant orange.
Hazel. Orange-pink.

J. J. Dean. Rose-pink.

Lilian Benners. Lavender.

Santa Cruz. Deep rose.

Victory. Deep salmon-red.

Ardenia-alba (White South African Bugle Lily).

All varieties, $\$ 3$ per doz., $\$ 20$ per 100

\section{Winter Aconite (Eranthis)}

Bright yellow flowers; valuable for naturalizing. Blooms in early spring. 50 cts. per doz., \$2.50 per 100, \$20 per 1,000.

\section{Hardy Bulbs for Naturalizing}

$\mathrm{N}$

ATURE never plants her flowers in beds and borders. She uses a wide brush and pIenty of color, and makes broad sweeps across the big outdoors. To imitate Nature and to surpass her in coloring is no small achievement, but it can be done by liberal planting of Hardy Bulbs suitable for naturalizing.

In naturalizing bulbs, plant them irregularly. Fill a basket with them and spill it on the ground. Plant the bulbs where they fall-close together in places, far apart in others. Take a quantity of bulbs and dribble them over the ground as you walk. Plant them where they fall. Make no attempt to be systematic or symmetrical. Nature does not work that way. Plant the bulbs with a dibble, making sure that there is no air-space beneath them, then leave them to the care of the great mother in her own outdoors.

CROCUSES. Large, trumpet-like flowers which come in February and March, before their leaves. About 6 inches high. Splendid on hillsides and banks among some low ground-cover or leaves. Shades of Blue, White, Striped, and Yellow. For separate colors, see page 39.

CHIONODOXA (GIory-of-the-Snow). Charming flowers somewhat like scillas, except that the blooms are held erect and are in many variations of blue and Iavender. See page 40.

FRITILLARIA. There are two kinds: the checkered Guinea-Hen Flower for meadows and stream-sides, and the Crown Imperial for showy spots in neglected corners. See page 41 .

HELLEBORUS (The Christmas Rose) Under trees or sheltering shrubs, with a slightly sunny exposure, these evergreen plants produce large, anemone-like flowers from November until March. See page 41.

LEUCO JUM (Spring Snowflake). Charming, bell-like flowers somewhat like a snowdrop, but Iarger and flowers Iater. See page 43.

LILY-OF-THE-VALLEY. Beautiful foliage for a ground-cover. Likes shade. Flowers sweet and fragrant. See page 37.
MUSCARI (Grape Hyacinth). Charming blue flowers like clusters of beads. 6 to 12 in. Plant in meadows. See page 43.

NARCISSUS. Plant them under trees, in meadows, beside brooks, on hillsideswherever a sweep of gold and creamy colors is desired in early spring. Combined with scillas and muscari, they make a lovely picture. See pages 23-27 for prices.

SCILLAS. Lovely blue flowers of the most exquisite tint. They bloom very early, covering the ground with sheets of blue, and spread quickly, soon taking possession of the space allotted them. Sibirica is best for naturalizing. The Campanulata varieties are taller and later. See page 43.

SNOWDROPS (Galanthus). Earliest flower of spring, with green and white bells peeping above the Iater snows. Plant on a sunny slope. See page 43.

SPECIES TULIPS. Charming, showy flowers in a wide variety of color. See page 21 for varieties and prices.

WINTER ACONITES. Brilliant yellow flowers which appear in late winter and early spring. Fine under trees and among stones. See above. 


\section{William M. Hunt \& Company}

\section{Hunt's Newport Golden Antirrhinum \\ (SNAPDRAGON)}

This remarkable, new, golden Snap originated in Newport, Rhode Island, several years ago, and was offered by us for the first time last year. It has been a sensational success with all growers, and is comparable in every way with Hunt's famous Geneva Pink.

The flowers are of extraordinary size, beautifully proportioned, clothing the spike from base to tip in a profuse, symmetrical array. The color shades from the delicate tint of a frosty lemon-ice to a rich golden yellow in the center of the lip.

When well grown, the strong, erect stems rise to a height of $j$ feet or more, bearing large, healthy foliage of firm, vigorous texture. Seed sown indoors in January and February produces excellent bloom in July and August. May-sown seed affords flowers of exhibition quality for November and December.

Hunt's Newport Golden is the most magnificent yellow Snap we know. It satisfies the long-standing demand for a well-clothed spike of deep yellow flowers. The older yellows are pale and uninteresting in comparison with this sunny marvel. The fullness of the spike, its ease of growth, freedom from disease, and its excellent keeping qualities give it a value far above that of any yellow Snap heretofore introduced. Pkt. \$2, 3 pkts. \$j.

\section{Hunt's Geneva Pink Antirrhinum (SNAPDRAGON)}

Unsurpassed by any new pink-flowering Snap, Hunt's Geneva Pink still reigns supreme, unrivaled and alone. Although dozens of pink varieties have been introduced in the past few years, none have combined as many excellent and useful qualities as this established variety.

When grown under glass, it produces marvelous 6-foot stems with $11 / 2$ to 2 feet of enormous, glistening, rose-pink flowers, densely packed, and yet so perfectly balanced that there is no effect of clubbiness or lack of grace. The glowing, fiery pink of the lip of the flowers is greatly enhanced by the pearly shade of the throat and upper petal.

Its stout stems are straight and bear large, dark, lustrous green foliage, seldom troubled by disease. The bloom is produced in abundant profusion, making it one of the most profitable Snaps to grow.

Geneva Pink is the most superb Snapdragon of its color we have ever seen grown under glass, and in the garden it produces wonderful spikes of bloom from early summer until frost.

The true originator's seed is obtainable only in our sealed packets. Pkt. \$1, 3 pkts. \$2.75. 


\section{Hunt's PERFECTION Seeds}

\section{Grass Seed Mixtures}

\section{Hunt's Perfection Lawn Seed}

This mixture is well worthy the name we have bestowed upon it, and we firmly believe is destined to become the favorite Grass Seed for use where a fine lawn is of importance. It is the result of careful study and trials made during the past few years under varied conditions. Those who have tried out this seed tell us that "we have got the real goods for a perfect lawn." Lb. 80 cts., 20 Ibs. $\$ 12.50,100$ Ibs. $\$ 60$.

Hunt's Perfection Lawn Seed contains 10 per cent South German Mixed Bent (Creeping Bent).

\section{Prospect Park Lawn Seed}

With proper care of the soil before sowing it will produce a rich, velvety Iawn in six to eight weeks, which will remain green throughout the year. For making new lawns we recommend 5 bushels to the acre; 1 pound of seed will sow 250 square feet; for renovating use one-half this quantity. Lb. 60 cts., 20 Ibs. $\$ 10,100$ Ibs. $\$ 45,1,000$ lbs. $\$ 425$.

\section{Hunt's Lawn Dressing Seed}

\section{Unsurpassed for Restoring Old Lawns}

Our Lawn Dressing Seed is a scientific blending of the Finest Lawn Seeds with those fertilizing elements that give nourishment to the rootlets, thus insuring perfect growth, fine texture, and deep, rich coloring. Germination and rapid growth are stimulated by its free use.

100-1b. bag, $\$ 40 ; 50-1 b$. bag, $\$ 21 ; 25-1 b$. bag, $\$ 11 ; 5-1 b$. bag, $\$ 3$

MIXTURE FOR SHADY LAWNS AND UNDER TREES. A combination of dwarfgrowing grasses which thrive in shaded places. It quickly produces an abundant and even growth of lovely green grass where ordinary lawn seed mixtures fail. Lb. 80 cts., 20 lbs. (bus.) $\$ 12.50,100$ lbs. $\$ 60$.

TERRACE LAWN SEED. A mixture of fine stoloniferous grasses specially suited to terraces. Will produce a rich and lasting turf. Sow at the rate of 2 pounds per 100 square feet. This mixture is a combination of such grasses as will make a quick, strong growth taking a firm hold of the soil and prevent washing away by heavy rains. Lb. 80 cts., 20 lbs. $\$ 12.50,100$ lbs. $\$ 60$.

TENNIS-COURT MIXTURE. Will make a firm, green and lasting turf in the shortest possible time, that will improve with trampling. Lb. 90 cts., 20 Ibs. $\$ 13.50,100$ lbs. $\$ 65$.

SEASHORE MIXTURE. This mixture is peculiarly suited to seaside lawns, etc. Lb. 80 cts., 20 Ibs. $\$ 12.50$, 100 Ibs. $\$ 60$.

POLO FIELD MIXTURE. A mixture of specially selected grasses for heavy trampling that will quickly recover from hard usage. 100 Ibs. $\$ 65,500$ Ibs. $\$ 300$.

\section{Grass Seed for Golf Courses}

Putting Green Mixture (Creeping Bent Formula). This 20 lbs. 100 lbs. 1,000 lbs. mixture can be relied upon to produce a beautiful turf of closest texture ..................... \$18 $50 \quad \$ 8500 \quad \$ 80000$

Putting Green Mixture (Chewing's Fescue Formula). A popular mixture used by many golf clubs with satisfactory results.

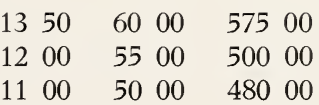

Fairway Mixture No. 1 . . . . . . . . . . . 1200

$\begin{array}{llll}50 & 00 \quad 480 & 00\end{array}$ 


\section{William $M$ iN Hunt $\operatorname{HuRATED}_{\mathcal{L}}$ Company}

\section{General List of Grasses}

Canada Blue Grass. Sow 60 Ibs. per acre. Weight per bus., 14 Ibs. . . .\$0 $65 \quad \$ 6000$

Chewing's Fescue. Weight per bus., 26 Ibs. . . . . . . . . . . . . 757000

Creeping Bent (South German Mixed Bent). Weight per bus., 16 Ibs. . . 17516500

Crested Dog's-Tail. Weight per bus., 20 Ibs. . . . . . . . . . . . . 656000

English Rye Grass. Sow 60 Ibs. to acre. Weight per bus., 24 Ibs. . . . 302500

Fine-leaved Fescue. Weight per bus., 16 Ibs. . . . . . . . . . . . 857500

Italian Rye Grass. 50 Ibs. per acre. Weight per bus., 18 Ibs. . . . . . 302500

Kentucky Blue Grass. Sow 70 Ibs. per acre for lawns, 40 Ibs. for pasture.

Weight per bus., 14 Ibs. . . . . . . . . . . . . . . . . . 656000

Meadow Fescue. Sow 45 Ibs. per acre. Weight per bus., 14 Ibs. . . . 353000

Orchard Grass. Weight per bus., 14 Ibs. . . . . . . . . . . . . . . . 454000

Red or Creeping Fescue. Sow 35 Ibs. per acre. Weight per bus., 14 Ibs. . $75 \quad 7000$

Redtop, Fancy, or Recleaned. Weight per bus., 32 lbs. . . . . . . . . 555000

Timothy. If used alone sow 30 Ibs. to the acre. Weight per bus., 45 Ibs. . $\quad 302400$

\section{Clovers}

Crimson or Scarlet (Trifolium incarnatum). Sow 15 to 20 pounds per Lb. $100 \mathrm{lbs}$. acre . . . . . . . . . . . . . . . . . $\$ 035 \$ 2750$

Alfalfa (Lucerne). 20 to 25 pounds per acre . . . . . . . . . . . . 605500

Alfalfa, Grimm's . . . . . . . . . . . . . . . . . . . . . . 858000

Alsike Clover. Sow 10 Ibs. per acre if used alone . . . . . . . . . . 555000

Medium Red Clover (Trifolium pratense). 20 Ibs. per acre . . . . . . 605500

Large Red or Pea Vine Clover (Trifolium pratense perenne). Sow 15 Ibs. 605500

Sweet Clover, Bokhara (Melilotus alba) . . . . . . . . . . . . 252250

White Clover (Trifolium repens). In spring at rate of 8 pounds per acre . $\quad \begin{array}{lll}75 & 70 & 00\end{array}$

Grass and Clover Seed prices are subject to market changes

\section{Permanent Pasture Grass Mixture}

No. 1 Mixture. For light soils Sow 40 pounds to the acre $100 \mathrm{lbs}$.

No. 2 Mixture. For medium soils . . . . . . . . . . . . . . . . . . . . . . . . . 5600

No. 3 Mixture. For heavy soils . . . . . . . . . . . . . . . . . . 5750

No. 4 Mixture. For hay only . . . . . . . . . . . . . . . 5400

No. 5 Mixture. For pasture only . . . . . . . . . . . . 5600

\section{Rye}

For grain, sow 1 bushel to the acre; for forage or soiling, 11/2 bushels (56 lbs. to the bushel) Giant Winter King. Good cover-crop. Bus. \$2.50, 10 bus. $\$ 22.50$.

Rosen Rye. An improved form of Russian Rye. Bus. \$3, 10 bus. \$27.50.

\section{Mushroom Spawn}

American Direct Pure-Culture. Produces Mushrooms in four to five weeks; uniform in shape, good size, and of a creamy white color. Per brick 50 cts., 10 bricks $\$ 4.50$, 50 bricks $\$ 21,100$ bricks $\$ 40$. Cultural directions free on request.

Spawn in bottles, $\$ 1.25$ each, 6 for $\$ 6$

SEMESAN. An effective remedy for the control of brown patch on Iawns and SEMESAN. putting-greens; also for treatment of seed, preventing blight, damping off, and mould. A special booklet telling all about Semesan free on request. 5 Ibs. $\$ 13,25$ Ibs. $\$ 62.50,100$ Ibs. $\$ 240$. 


\section{Seasonable Garden Sundries}

For complete list, see Spring Catalog. Sent free on request.

All prices subject to change without notice.

\section{Fertilizers, Manures, Etc.}

Adco. An artificial stable manure. The process consists of making a heap of all garden trash as it is collected and adding Adco. In three or four months the heap is converted into a pile of excellent manure. Bags of 150 lbs. for $\$ 10.50$.

Bentley's Carnation Manure. One of the best aids to successful carnation culture. 56 Ibs. \$9, 112 Ibs. \$17.

Bentley's Sweet Pea Manure. 112 Ibs. S15.

Bone-Meal for General Use. (Steamed.) 100 lbs. \$4.50, ton \$70.

Bone-Meal, Raw, Fine-Ground. 100 Ibs. $\$ 5.50$, ton $\$ 90$.

Bone-Meal, for Roses. 100 Ibs. \$5, ton $\$ 80$.

Clay's Fertilizer. Highly concentrated plantfood. 28 Ibs. $\$ 4,56$ Ibs. $\$ 7,112$ Ibs. $\$ 13.50$.

Humus, Hyper. In carload lots, in bulk at $\$ 9.50$ per ton; in bags, $\$ 30$ per ton.
Lawn Sand. Kills dandelions, etc.; fertilizes the Iawn. $56 \mathrm{Ibs}$. \$10, 112 Ibs. \$18.

Rhodono. The aluminum sulphate compound. For rhododendrons, azaleas, heaths, mountain Iaurel, etc. 100 Ibs. S5, ton $\$ 85$.

Scotch Soot. Promotes dark green foliage. Bag (approximately 100 Ibs.) \$7.50.

Sheep Manure, Pulverized. 100 Ibs. \$4.50, ton $\$ 70$.

Sulphate of Ammonia. Excellent for improving Iawns and putting greens. 100 Ibs. $\$ 6.50,200$ Ibs. \$12.

Thomson's Chrysanthemum Manure. 28 Ibs. \$4.50, 56 Ibs. \$8, 112 lbs. \$15.

Thomson's Vine and Vegetable Manure. Excellent for vine borders and potted plants. 56 Ibs. $\$ 6,112$ Ibs. $\$ 11.50$.

\section{Potting Materials}

Charcoal, Dust. 100 Ibs. \$6.

Lump. For orchids, etc. $100 \mathrm{lbs}$. \$6.50.

Moss, Dry Sphagnum. Bale \$4.50.

Live Green Sphagnum. Bag $\$ 4.50$.

Sheet. For florists' work. Bag \$5.
Peat, Fibrous. For ferns. Bag \$3.75.

For Orchids. Bag \$4.

Peat Moss, Granulated. Keeps soil moist; adds fertility to the soil. Bale $\$ 4,5$ bales $\$ 18.75$.

\section{Insecticides}

Agripax. Contact pyrethrum insecticide. Gal. \$3.50, 5 gals. \$12.

Antrol. Exterminates ants. Pt. \$1.

Ansect Rose-Bug Destroyer. Qt. \$1.50, gal. $\$ 5.50$.

Aphine. Destroys aphis, thrips, mealy bug, etc. Qt. \$1, gal. \$3.25, 6 gals. \$18.

Black-Leaf 40. Kills black aphides and sucking insects. 2 Ibs. \$3.75, 10 Ibs. \$12.

Bordeaux Mixture. Effective against blight and fungus. Liquid, gal. S2.25, 5 gals. \$9.25. Paste, 5 Ibs. \$1.50, 25 lbs. \$5.25.

Borowax. Effective protection against all tree borers. Gal. \$2.50, 6 gals. \$12.

Copper Solution. Prevents mildew. Qt. $\$ 1.50$, gal. \$3.75.

Cutworm Killer. 5 Ibs. \$2, 25 Ibs. \$8.

Ever Green. Very effective against all kinds of insects. 2 Ibs. \$3.50, gaI. \$13.

Fungine. Remedy for mildew, wilt, and rust. Qt. \$1, gal. \$3.50, 12 gals. \$36.

Fungtrogen. A highly concentrated fungicide that conquers mildew and controls blackspot on roses, phlox, and other plants. $1 / 2$ gal. $\$ 3.50$, gal. \$6.
Imp Soap Spray. Kills aphis, etc. Gal. \$3.50, 5-gal. keg \$12.50.

Lemon Oil. Kills green and black fly. Qt. $\$ 1.25$, gal. \$4, 10 gals. \$25.

Mologen. Eliminates moles within two to three davs; non-poisonous to humans and pets. 5-İb. can $\$ 4$.

Nico-Fume Liquid. For spraying and fumigating. Lb. $\$ 2.35,4$ Ibs. \$8, 8 lbs. \$15.

Nico-Fume Paper. For fumigating. 24 sheets $\$ 1.25,144$ sheets $\$ 5.25,288$ sheets $\$ 9.50$.

Nicofume Powder. Economical and effective. 5 lbs. S4, 10 lbs. \$7.50.

Pyrox. Combined insecticide and fungicide. 5 Ibs. \$2, 10 lbs. \$3.75, 25 Ibs. \$8.

Red-Arrow (Pyrethrum) Insecticide. One of the most reliable all-round insecticides on the market today. 1/2pt. \$1.75, qt. \$6, gal. \$20.

Scalecide. Destroys San José Scale. Gal. $\$ 1.75,30$ gals. $\$ 25,50$ gals. $\$ 40$.

Semesan. For the prevention of brown patch, etc. 5 Ibs. \$13.

Tobacco Dust. 100 Ibs. \$5.

Tobacco Stems. 100 Ibs. $\$ 4,300$ Ibs. $\$ 10.50$. 


\section{William $M_{\text {INCORPORATED }}$ Company}

\section{INSECTICIDES, continued}

Weed Killer. (Key Brand.) One gallon makes 25 gallons for use. Gal. \$2, 5 gals. $\$ 7.50,50$ gals. $\$ 54$.

Weed Killer. (Atlas Non-Pcisonous.) Will exterminate all undesirable vegetation, including poison ivy, as easily as watering a garden, without endangering human or animal iife. 1-gal. can $\$ 2,5$-gal. drum $\$ 8$, 50-gal. drum $\$ 55$.
Wilson's O. K. Plant Spray. Very effective against all plant aphis. Gal. \$3, 5 gals. $\$ 12,10$ gals. $\$ 20,50$ gals. $\$ 90$.

Worm Eradicator, X-L-ALL. For lawns, putting greens, croquet-grounds, etc. Can be used at any season of the year. 28 Ibs. $\$ 3.50,56$ Ibs. $\$ 6.50,112$ Ibs. $\$ 12.50$.

$\mathrm{X}$-L-ALL Insecticide. Kills mealy bug, etc. GaI. \$9, 5 gals. \$40

\section{Spraying and Watering Supplies}

Auto Sprayer, Brown's No. 9B. Brass tank "Auto Pop" nozzle. \$10.

Waterfan Oscillating Irrigator. No. 6 will spray an area $15 \times 45$ feet, \$15; No. 8 will spray an area $25 \times 45$ feet, $\$ 18$.

GARDEN HOSE.

Electric Garden Hose. Undoubtedly the most satisfactory Hose. 3/4-in., \$22 per $100 \mathrm{ft}$.; $1 / 2$-in., $\$ 18$ per $100 \mathrm{ft}$.

Abol Syringe. Makes an exceptionally fine spray; two roses, angle neck, and drip preventer; solid brass. $\$ 12$ each.

The Stott Sprayer. For under foliage. Single Nozzle, \$2; Double Nozzle, \$3.

The Boston Nozzle. Throws coarse or fine spray. $3 / 4$-in., $\$ 1$.

The Boston Rose-Hose Sprinkler. 3-in. face, $\$ 1 ; 4$-in. face, $\$ 1.50$.
Turbo Rotary Oscillator. Ideal for tenniscourts and putting greens. \$22.50.

Peacock Lawn Sprinkler (Skinner System). $121 / 2 \mathrm{ft}$. Iong (on wheels), 56 nozzles, sprays $15 \times 60 \mathrm{ft} ., \$ 20$.

Watering-cans, Haws' Pattern. 3-qt. (shelf) \$4; 4-qt. \$5.25; 6-qt. \$5.75; 8-qt. \$6.75; 10-qt. $\$ 7.50$.

Haws' Own Make. 3-qt. S5; 4-qt. \$6.75; 6 -qt. \$8; 8-qt. \$9.50; 10-qt. \$10.50.

Haws' Own Make. Galvanized. 4-qt. \$7.50; 6-qt. \$9.25; 8-qt. \$10.50; 10-qt. \$11.50.

French. 6-qt. \$6; 8-qt. \$6.75; 10-qt. \$7.50; 12-qt. $\$ 8$.

Philadelphia. 4-qt. \$4; 6-qt. \$4.50; 8-qt. S5.25; 10-qt. $\$ 6.25 ; 12$-qt. $\$ 6.75 ; 16$-qt. $\$ 8.50$.

\section{Canes and Plant Supports}

Bamboo Canes. Genuine Chinese; natural, strong, heavy. $4 \mathrm{ft}$. $x \frac{1}{2} / \mathrm{in}$. diam. $5 \mathrm{ft} . \mathrm{x} \frac{1}{2}$-in. diam. $6 \mathrm{ft} . \mathrm{x} 3 / 4$-in. diam. $8 \mathrm{ft}$. $1 / 2$-in. diam.

Bamboo Canes, Japanese. Natural. Thin and light.

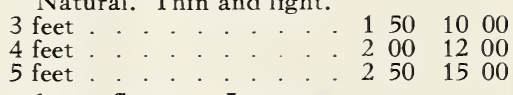

Bamboo Canes, Japanese. Painted green. 3 feet. 4 feet $\begin{array}{rrrr}100 & 1,000 \\ \$ 4 & 00 & \$ 35 & 00 \\ 5 & 50 & 50 & 00 \\ 6 & 50 & 60 & 00 \\ 8 & 00 & 75 & 00 \\ & & & \\ & & & \\ 1 & 50 & 10 & 00 \\ 2 & 00 & 12 & 00 \\ 2 & 50 & 15 & 00\end{array}$ 5 feet
Wire Stakes. Galvanized.

3 feet 100

4 feet

5 feet

Dahlia Poles, Square. Extra heavy.

5 feet

6 feet

6 feet only, $1 \frac{1}{4} \times 1 \frac{1}{4}$ in.

Dahlia Poles, Round. Painted green.

5 feet

6 feet

Plant Stakes. Round, painted green.

3 feet

4 feet

1050

5 feet

\section{Garden Tools}

Hedge Trimmers, Little Wonder. Each It simplifies hedge trimming; easy to operate. 30 -in. 40-in.

2750

Rakes, Wooden. For Iawns Hay. 26 teeth \$1.25; 28 teeth Daisy Rakes. Imported Japanese Bamboo Leaf-Rakes

Scythes, English Lawn. 38-in.

400

Scythe Snath or Handle.

Scythe Stones. Doz: $\$ 3.50$
Shears. Hedge, Ridal's Patent. Im- Each ported. 9-in. . . . . \$8 50 Grass Border. 8-in. \$6; 10-in. . . 700 Sheep or Grass . . . . . . . . 150

Sickles or Grass Hooks. English . . 150

Trowels, Solid Steel Socket Shank. 6 -in. 75 cts.; 7 -in.

\section{Knives}

Budding Knives. No. 204B. . . . . 375 204. 207. 


\section{Hunt's Garden Requisites}

\section{Shears}

Scissors, Grape-thinning. 7-in.

Each

Pruning Shears, X-L-ALL. The best 8 -in. English Shears. 7-in.

Pruning Shears, California. 9-in.
Pruning Shears, Kunde. Imported. 8 -in. $81 / 2$-in.

Each $\$ 575$

$\begin{array}{ll}5 & 50 \\ 5 & 75\end{array}$

600

350

Rolcut. The new idea in Pruning Shears. Very strong, effective, and low in price

\section{Tying Materials, Etc.}

Raffia, White. Long and broad. Lb. 60 cts., Sea Island. 8 balls to a box. $\$ 1.50$ per box. 5 lbs. $\$ 2.50$.

Green. Lb. $\$ 1.25,5$ Ibs. \$6.

Silkaline. For stringing smilax, etc. Box of eight 2-oz. spools, Fine, Medium, or Coarse, $\$ 3$.

Soft Jute. For vines, 3 and 5-ply. In balls at 60 cts. per Ib.

Tarred. Thin, 1-lb. balls, 95 cts.; Medium, 1-Ib. balls, 90 cts.; Thick, 1 -lb. balls, 85 cts.

\section{Lawn Mowers}

Coldwell's Imperial Mower.

10-inch high wheel. 4-blade 5-blade 16-in.

18-in.

$\$ 2000 \quad \$ 22 \quad 50$

$2200 \quad 2400$

Townsend's Victory Mower. 16-in.
Pennsylvania Lawn Mowers. Junior. High wheel. 17-in. Junior. Low wheel. 16-in.

Each

$\$ 3400$

3200

Standard. Low wheel. 14-in. . . . 2800 16-in. . . . . . . . 3200

\section{Miscellaneous Sundries}

Barrows, Garden No.4. Medium size. .\$8 50 Baskets, English Garden.

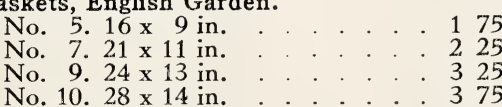

No. $10.28 \times 14$ in. 375

Baskets, Strawberry. 1-qt., $\$ 2$ per 100 $\$ 17.50$ per 1,$000 ; 2$-qt., $\$ 2.75$ per 100 , $\$ 25$ per 1,000 .

Baskets, Vegetable.

No. 2. $21 \times 12 \times 61 / 2$ in.

No. 4. $28 \times 15 \times 8$ in.

Each

Nc. 5. $25 \times 16 \times 81 / 2$ in.

$\$ 200$

2. 75

300

Brooms, English Birch. $\$ 1$ each, $\$ 10$ per doz.

Burlap, Wrapping. For protecting plants. In lengths 25 to 200 yards. Yard

No. 1 quality, 36 in. wide . . . . \$0 22

No. 1 quality, 48 in. wide

No. 1 quality, 54 in. wide

No. 1 quality, 72 in. wide

22

33

Boxes, Flower, Corrugated Cardboard. Very

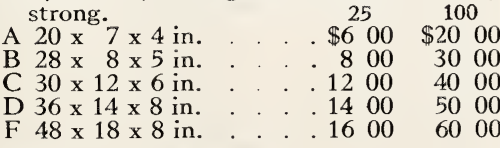

Boxes, Flower, Cardboard.

$18 \times 5 \times 3$ in.

650

$24 \times 8 \times 5$ in.

1200

$25 \times 15 \times 8$ in.

1750

$28 \times 8 \times 5$ in.

1450

$28 \times 8 \times 6$ in.

1500

$30 \times 10 \times 6$ in.

Celery Bleachers, Ball's Pattern.

$7 \times 14$ in., $\$ 5$ per $100, \$ 45$ per 1,000 .
Flower Pots. Sizes, height and width, inside.

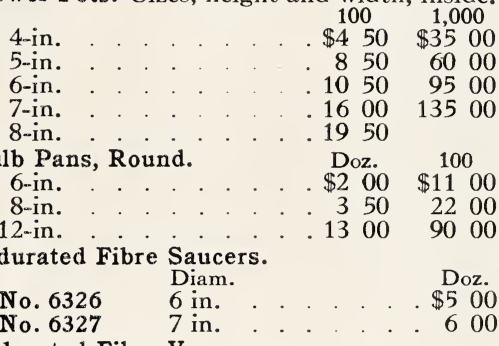

Indurated Fibre Vases.

$\begin{array}{lllll} & \text { Depth } & \text { Diam. } & & \text { Doz. } \\ \text { No. } 0 & 131 / 2 \text { in. } & 83 / 4 \text { in. . } & . & \$ 2400 \\ \text { No. } 1 & 10 \text { in. } & 6 \text { in. . . . . } 2000 \\ \text { No. } 33 & 12 \text { in. } & 43 / 4 \text { in. . . . . } 2200 \\ \text { No. } 44 & 83 / 4 \text { in. } & 31 / 2 \text { in. . . . . } & 1800\end{array}$

Galvanized Vases. For cut-flowers. Painted green, very durable.

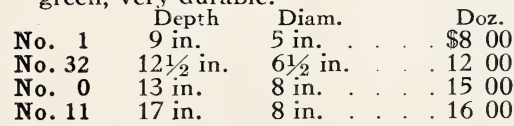

Grape Bags, Paper. $\$ 2$ per $100, \$ 19$ per 1,000 .

Gloves, Gardeners'. For pruning. Pair $\$ 2.50$.

Labels, Wooden, Pot and Gar- $100 \quad 1,000$ den. 5-in., painted. . . \$2 50 6-in., painted . . . 275 8-in., painted . \$1 25850 10-in., painted . . . . . . 1501100 12-in., painted . . . . . 1601450 $31 / 2$-in. (copper wire tree), painted 


\section{William M. Hunt \& $\underset{\text { IN CORPORATED }}{\mathcal{E}}$ Company}

\section{MISCELLANEOUS SUNDRIES, continued}

Copper Labels, complete with stylus. \$2 per 100.

Simplex Weatherproof Garden Labels. No. $1,3 \times 1 / 2$ in., $\$ 3$ per 100 ; No. $2,4 \times 3 / 4$ in., $\$ 5$ per 100 ; No. $3,5 \times 1$ in., $\$ 7$ per 100 .

Simplex Garden Labels. No. $10,23 / 4$ x $1 \frac{1}{2}$ in., 24 in. high, \$3 per doz.; No. 11, $3 \mathrm{x}$ 2 in., 24 in. high, $\$ 3.60$ per doz.

Pencils, Indelible. For marking Iabels. 20 cts. each.

Mats, Frost-Proof, Burlap. No. 2D. Waterproof duck, one side. Each Doz. $40 \times 76$ in. . . . . \$4 $50 \$ 4000$ $76 \times 76$ in. . . . . . 5506000

Melon Nets. Imported. \$20 per 100 .

Mole Traps, Olmsted's. \$2.50 each.

Netting. For fruit protection.

No. 1. $60 \times 30 \mathrm{ft}, 21 /$-in mesh Each No. 2. $120 \times 29 \mathrm{ft} ., 2 \frac{1}{2}$-in. mesh 5000

Paper, White Tissue. $24 \times 36$ in. Lb. 60 cts., 10 Ibs. (ream) $\$ 5$.

Parceling on Rolls, Kraft. 18 in. wide, weight 25 Ibs., $\$ 5$.

24 in. wide, weight 39 Ibs., $\$ 7.75$

36 in. wide, weight 60 Ibs., \$11.50.
Paper, Waxed, White. $18 \times 24$ in., $24 \times 36$ in., 10 Ibs., \$5.

Thermometers, Japanned. Standard Grade. 8-inch, $\$ 1.50 ; 10$-inch, $\$ 1.75$.

Mushroom Bed. Galvanized frame. $\$ 3$ each.

Self-registering. Copper case; black brass scale, white figures. Maximum and Minimum. 10-inch, $\$ 6.50$.

Summer Cloud. An English preparation for shading greenhouses. Per can, 75 cts.

Tubs, Cedar Plant. Round.

Painted green.

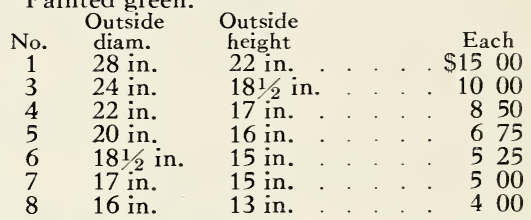

Wall Nails, Chandler's Patent. 11/4-in., $\$ 2$ per box; $1 \frac{1}{2}$-in., $\$ 2.25 ; 2$-in., $\$ 2.50$.

Wall Nails, Vyn-tach. Specially adapted for masonry. Complete with Drill, Holder, and Leaded Nails. \$2 per box.

\section{Contents}

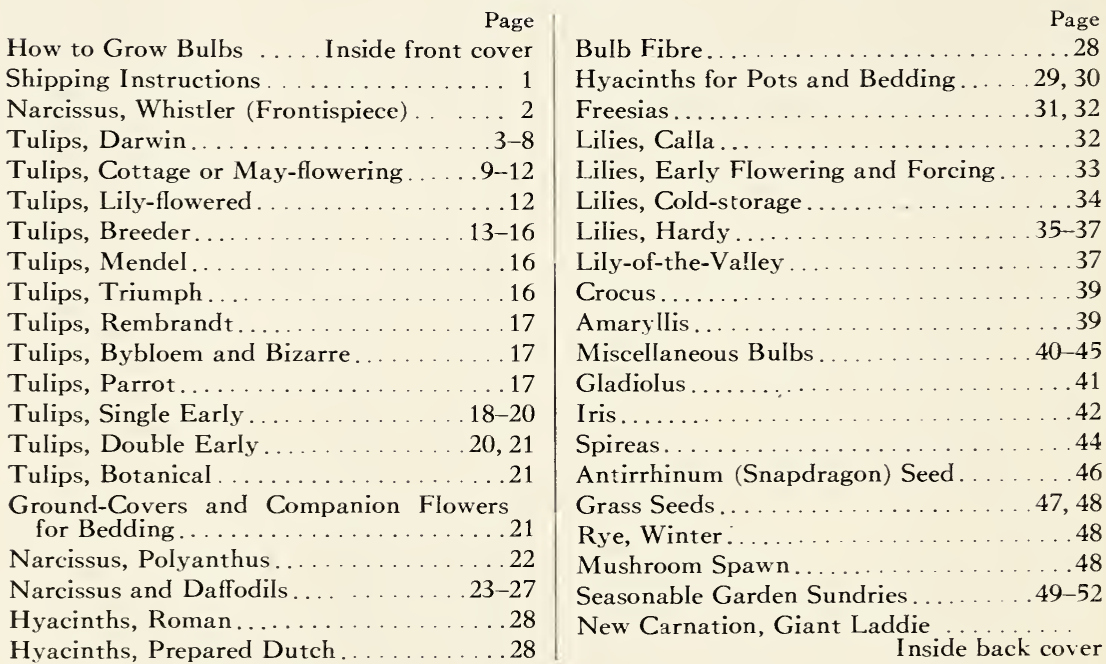

For complete list, see Spring Catalog, free on request. 


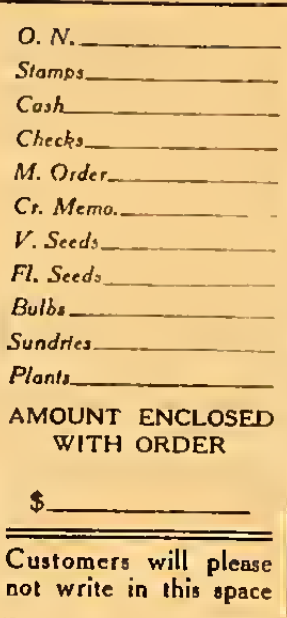

115 West 45th Street, New York City

Xan Please write Name and Address very distinctly. Attention to this will probably save unnecessary delay.

$$
\text { Date }_{-}
$$

Name

P. O. Box, Street

or Rural Delivery

Post Office

County. State

\section{Station or}

Express Office

$$
\text { Only if different from Post Ofice }
$$

Send by

Superintendent, Gardener, or Farmer

BULBS ARE LOW-PRICED THIS YEAR-BUY LIBERALLY

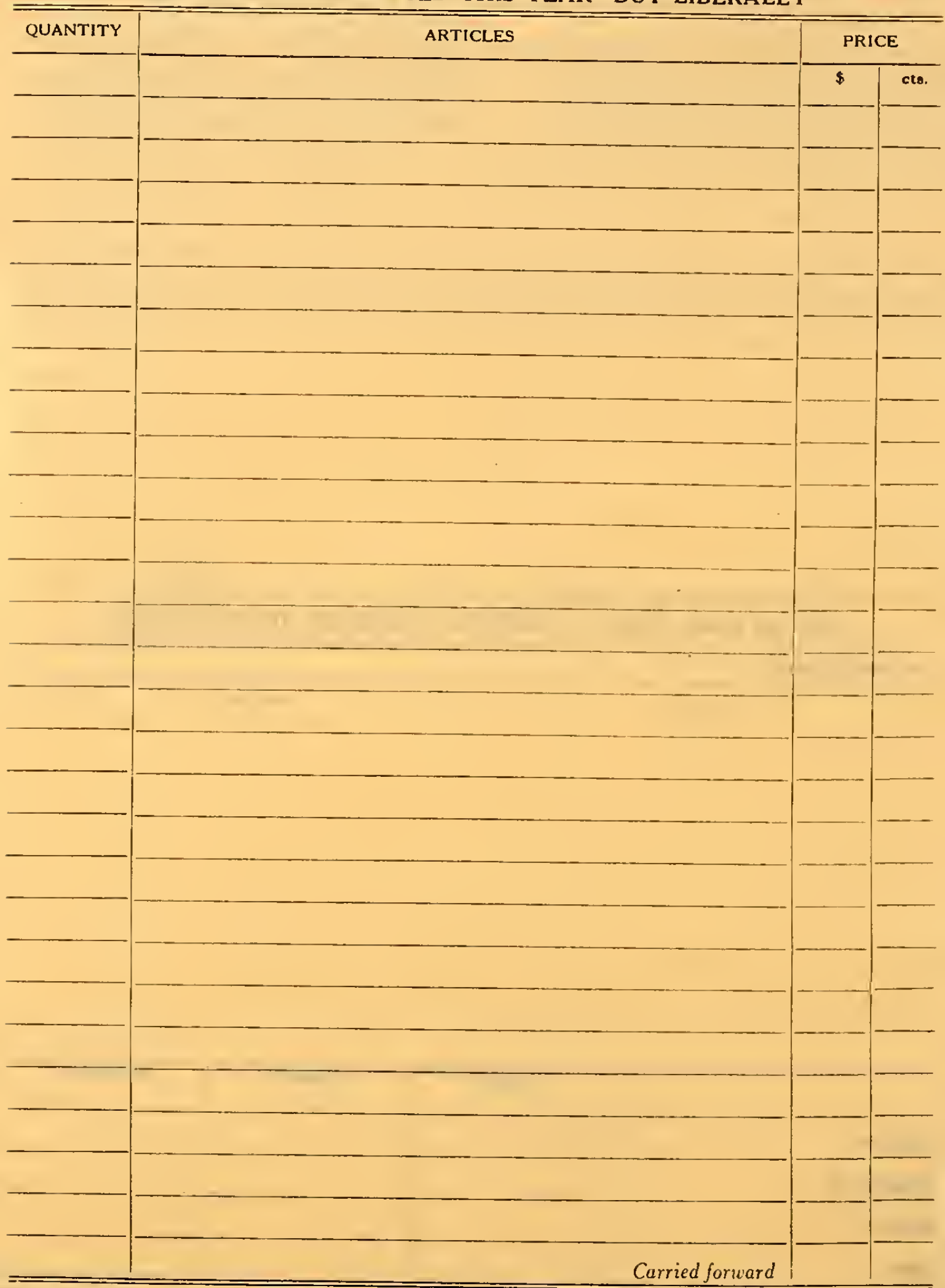




\section{N E W C A R N A T I O N}

\section{Giant Laddie}

Gorgeous, big blooms of deep, glowing rose-pink, richer and more luminous than the original Laddie, frequently reaching 4 to 5 inches in diameter. The stems are particularly good, and the plant is an exceptionally clean grower and free bloomer. Received a Gold Medal from the Massachusetts Horticultural Society, the Silver Medal at the New York Flower Show, and has been a sensational success at all shows where it has been exhibited. Stocks are scarce; please place orders early.

Rooted cuttings, $\$ 20$ for 25 $\$ 75$ per 100

Not less than 25 sold 


$$
\text { +1 }
$$
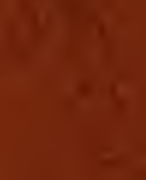